\title{
RESISTÊNCIA DE LIMA ÁCIDA 'TAHITI’ À BAIXA TEMPERATURA: TRATAMENTOS TÉRMICOS E ENVOLVIMENTO DO ETILENO
}

\author{
MARIA LUIZA LYE JOMORI
}

Dissertação apresentada à Escola Superior de Agricultura "Luiz de Queiroz", Universidade de São Paulo, para obtenção do título de Mestre em Ciências, Área de Concentração: Fisiologia e Bioquímica de Plantas.

P I R A C I C A B A

Estado de São Paulo

Junho-2005 


\title{
RESISTÊNCIA DE LIMA ÁCIDA 'TAHITI’ À BAIXA TEMPERATURA: TRATAMENTOS TÉRMICOS E ENVOLVIMENTO DO ETILENO
}

\section{MARIA LUIZA LYE JOMORI}

Engenheiro Agrônomo

Orientador: Prof. Dr. RICARDO ALFREDO KLUGE

\begin{abstract}
Dissertação apresentada à Escola Superior de Agricultura "Luiz de Queiroz", Universidade de São Paulo, para obtenção do título de Mestre em Ciências, Área de Concentração: Fisiologia e Bioquímica de Plantas.
\end{abstract}

P I R A C I C A B A

Estado de São Paulo

Junho-2005 
Dados Internacionais de Catalogação na Publicação (CIP) DIVISÃO DE BIBLIOTECA E DOCUMENTAÇÃO - ESALQ/USP

Jomori, Maria Luiza Lye

Resistência de lima ácida 'Tahiti' à baixa temperatura: tratamentos térmicos e envolvimento do etileno / Maria Luiza Lye Jomori. - - Piracicaba, 2005.

116 p. : il.

Dissertação (mestrado) - - Escola Superior de Agricultura Luiz de Queiroz, 2005.

Bibliografia.

1. Antioxidante 2. Baixa temperatura 3. Conservação de alimento por refrigeração 4. Etileno 5. Limão 6. Pós-colheita I. Título

CDD 634.334

"Permitida a cópia total ou parcial deste documento, desde que citada a fonte - O autor" 
Aos meus pais Kasuki e Marico Jomori

pelo constante incentivo, amor e carinho.

Aos meus irmãos Douglas e Nancy e a minha avó Kiyoko, Que partilham comigo desta vitória.

Aos meus amigos,

que foram peça fundamental, meu apoio

para que eu chegasse até aqui!

DEDICO. 


\section{AGRADECIMENTOS}

A Deus, por sempre estar presente em minha vida, possibilitando mais vitória.

À Escola Superior de Agricultura 'Luiz de Queiroz', Universidade de São Paulo, pela possibilidade de realização deste curso, em especial, o Curso de Fisiologia e Bioquímica de Plantas.

Á Fundação de Amparo à Pesquisa do Estado de São Paulo - FAPESP pela concessão da bolsa, possibilitando a realização do meu estudo.

Ao Prof. Dr. Ricardo Alfredo Kluge pela orientação, amizade, incentivo e dedicação demonstrada em cada etapa deste trabalho.

Ao Prof. Dr. Ângelo Pedro Jacomino pelo incentivo a trabalhar e estudar pós-colheita de produtos hortícolas, e pela amizade e disponibilidade do uso dos equipamentos do laboratório e câmara fria.

Ao Prof. Dr. Ricardo Azevedo Antunes pela realização das análises das enzimas antioxidativas, e a todos de seu laboratório, em especial, a Salete e Priscila pelos ensinamentos e paciência.

À Profa ${ }^{\text {a }}$ Dra . Giuseppina Lima pela realização das análises dos teores de poliaminas, e pelas sugestões e ensinamentos na área de bioquímica. 
Aos docentes da ESALQ/USP, por compartilharem seus conhecimentos durante este período de minha formação.

Aos funcionários do Departamento de Ciências Biológicas e Produção Vegetal, que de alguma forma colaboraram para a realização desse trabalho.

Ao produtor Sr. José Carlos Andrade, do Sítio da Chuva, pela doação dos frutos para a realização dos experimentos e pela confiança.

À Maria Solizete, secretária do PPG em Fisiologia e Bioquímica de Plantas, pelas inúmeras vezes que me auxiliou.

Aos companheiros do grupo de Fisiologia e Bioquímica Pós-colheita, pelo apoio na instalação e condução do experimento, principalmente à Baty, Baguiña, Carol, Graça, Fernando e Robertinha, pela amizade e companheirismo.

Ao técnico do Laboratório Pós-colheita Marcos Trevisan e às amigas Aninha, Cecília, Flávia e Raquel, pelo auxílio na realização das análises. À minha amiga Voa, pela incansável ajuda nos momentos mais difíceis, pelos conselhos e pela grande amizade!!

Às minhas irmãzonas Dinha, Foker, Relpi, Tafassiu e a caçulinha Porva, que me apoiaram em todo o momento com companheirismo e muita paciência, muito obrigada mesmo, sem vocês não seria possível!!

Á república Kza Verde, minha segunda família, minha eterna gratidão, a todas que um dia deixaram seu pedacinho e àquelas que um dia 
deixarão para a consolidação dessa grande família!! Em especial a Voa, Noti, Magrela, Bicuti, Mandi, Kuiq, Cô, Perla, Ruty, Papas, Lele, Toiça, Ecruzis, Frista, Xop, Nid, Pudim, Tele, Bororó, Rodada e Tejano, muito obrigada meninas!

Aos integrantes do Dral, pelo apoio e amizade, em especial ao 1/2 Kura, Zino e Bota.

Aos colegas do curso de Pós-graduação em Fisiologia e Bioquímica de Plantas pela agradável convivência, principalmente à amiga Maitê, pela amizade, força e muito carinho.

À minha família, pelo amor e apoio nessa etapa de minha vida.

E a todos que de alguma forma contribuíram para a realização deste trabalho 


\section{SUMÁRIO}

Página

RESUMO

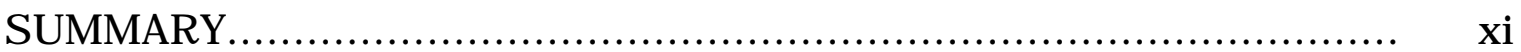

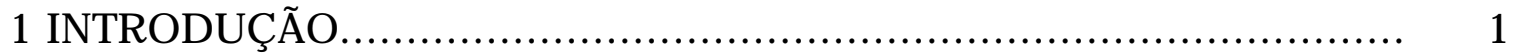

2 REVISÃO DE LITERATURA................................................ 4

2.1 Importância da cultura................................................. 4

2.2 Injúria pelo Frio e Métodos de controle............................. 5

2.3 Mecanismos de Defesa da Planta.................................... 9

2.3.1 Poliaminas.......................................................... 9

2.3.2 Enzimas Antioxidantes............................................ 12

2.4 Etileno............................................................. 16

2.4.1 Bloqueadores da Produção e Ação do Etileno........................ 19

3 TRATAMENTOS TÉRMICOS COMO FORMA DE AUMENTAR A RESISTÊNCIA DE LIMA ÁCIDA ‘TAHITI’ À BAIXA TEMPERATURA

Resumo............................................................... 21

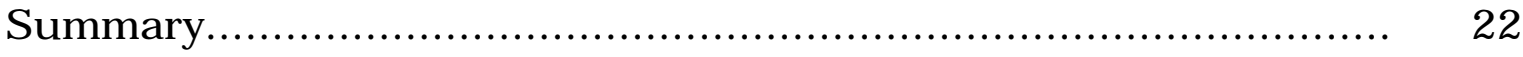

3.1 Introdução......................................................... 22 
3.2 Material e Métodos........................................................ 25

3.3 Resultados e Discussão.................................................. 32

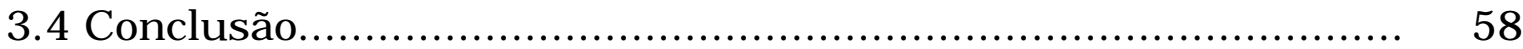

4 ENVOLVIMENTO DO ETILENO NO DESENVOLVIMENTO DA RESISTÊNCIA DE LIMA ÁCIDA 'TAHITI’ À BAIXA TEMERATURA

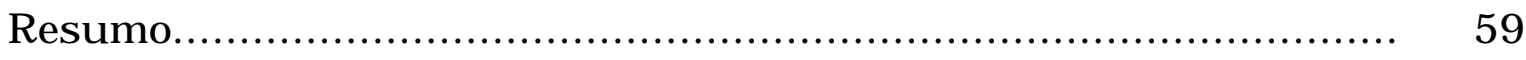

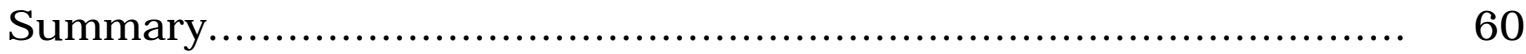

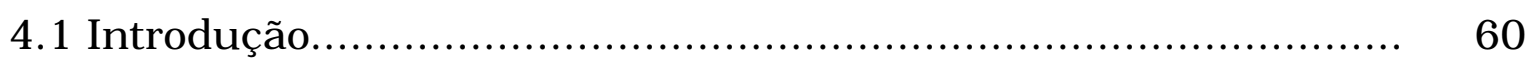

4.2 Material e Métodos............................................................ 62

4.3 Resultados e Discussão.................................................... 69

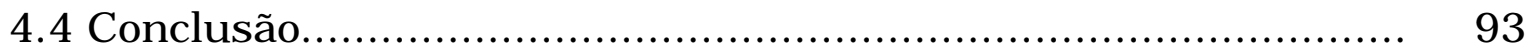

5 CONSIDERAÇÃO FINAL_........................................................... 94

REFERÊNCIAS BIBLIOGRÁFICAS............................................ 95 


\title{
RESISTÊNCIA DE LIMA ÁCIDA 'TAHITI' À BAIXA TEMPERATURA: TRATAMENTOS TÉRMICOS E ENVOLVIMENTO DO ETILENO
}

\author{
Autora: MARIA LUIZA LYE JOMORI \\ Orientador: Prof. Dr. RICARDO ALFREDO KLUGE
}

\section{RESUMO}

A refrigeração é o método mais recomendado para o armazenamento de frutas e hortaliças, estendendo dessa forma o período de comercialização desses produtos. Entretanto, dada à sensibilidade dos citros à baixa temperatura, o seu armazenamento por longos períodos é dificultado, considerando que, invariavelmente, os sintomas de injúrias pelo frio surgem durante a fase de comercialização, após a retirada do produto da condição refrigerada. O objetivo deste trabalho foi avaliar o mecanismo de resistência dos frutos de lima ácida 'Tahiti' a baixa temperatura. No primeiro experimento foram avaliados tratamentos térmicos, que consistiu em condicionamento rápido $\left(53^{\circ} \mathrm{C} / 3 \mathrm{~min}\right)$, condicionamento lento $\left(37^{\circ} \mathrm{C} / 2\right.$ dias) e aquecimento intermitente ( ciclos de 6 dias a $1^{\circ} \mathrm{C}+1$ dia a $25^{\circ} \mathrm{C}$ ). No segundo 
experimento foi avaliado o envolvimento do etileno na resistência a baixa temperatura, utilizando tratamento com ethephon (2000 $\mathrm{mg} \mathrm{L}^{-1}$ ), 1-MCP (1000 nL L-1), ácido salicílico (2000 $\mathrm{mg} \mathrm{L}^{-1}$ ) e a associação de 1-MCP e ácido salicílico nas mesmas concentrações. Os frutos foram armazenados a $1^{\circ} \mathrm{C}$ por 45 dias, sendo avaliados a cada 15 dias, mais 3 dias de comercialização simulada. As determinações consistiram em incidência de injúria pelo frio, produção de etileno, taxa respiratória, características físico-químicas (porcentagem de suco, teor de sólidos solúveis totais, acidez titulável, "ratio", índice tecnológico, teor de ácido ascórbico e coloração da casca), atividade das enzimas antioxidantes e teor de poliaminas. Observou-se que os frutos que foram submetidos ao aquecimento intermitente apresentaram menor incidência de injúria pelo frio, menor redução no teor de ácido ascórbico bem como menor taxa respiratória e menor produção de etileno, até 45 dias de armazenamento refrigerado, podendo esta resistência à baixa temperatura estar associada com a atividade das enzimas antioxidativas. Os frutos submetidos ao condicionamento térmico rápido mantiveram a qualidade dos frutos somente até 15 dias de armazenamento. Não foi possível verificar correlação entre etileno e resistência a baixa temperatura, uma vez que não teve diferença entre os tratamentos na incidência de injúria pelo frio. 


\section{RESISTANCE OF 'TAHITI’ LIME AT LOW TEMPERATURE: HEAT TREATMENTS AND INVOLVEMENT OF ETHYLENE}

Author: MARIA LUIZA LYE JOMORI

Adviser: Prof. Dr. RICARDO ALFREDO KLUGE

\section{SUMMARY}

Cold storage is the most recommended method for storage of fruits and vegetables and therefore, extending their marketing period. However, due to the low temperature sensibility of some fruits like citrus, the storage for long periods is very difficult, since the symptoms of chilling injuries en mane case, occur during the commercialization, after removal of the fruit from cold storage. The objective of this study was evaluate the resistance mechanism of 'Tahiti' lime to low temperature. In the first experiment heat treatments were evaluated, which consisted in water heat treatment $\left(53^{\circ} \mathrm{C} / 3 \mathrm{~min}\right)$, air heat treatment $\left(37^{\circ} \mathrm{C} / 2\right.$ days) and intermittent warming (cycles of 6 days at $1^{\circ} \mathrm{C}+1$ day at $25^{\circ} \mathrm{C}$ ). In the second experiment ethylene involvement at low temperature resistance was evaluated using treatments with ethephon (2000mg L-1), 1-methylcyclopropene (1000 nL L-1), salicylic 
acid (2000mg L-1) and association of 1-MCP with salicylic acid. Fruit were stored at $1^{\circ} \mathrm{C}$ for 45 days, being evaluated each 15 days (plus 3 days of simulated marketing at $25^{\circ} \mathrm{C}$ ). Incidence of chilling injury, ethylene production, respiratory rate, physical and chemical characteristics (juice percentage, soluble solids concentrations, titratable acidity, ratio, technological index, ascorbic acid content and skin color), antioxidant enzymes activity and polyamines content were evaluated. It was observed that fruit submitted to intermittent warming did not show chilling injury, lower reduction on the ascorbic acid content as well as a lower respiratory rate and lower ethylene production, up to 45 days of old storage. This higher resistance to low temperature might be associated with the activity of antioxidant enzymes. It wasn't possible to verify the correlation between ethylene and low temperature resistance, once there was no difference between treatments in chilling injury incidence. 


\section{INTRODUÇÃO}

A produção de lima ácida 'Tahiti' (Citrus latifolia T.) vem crescendo e ocupando lugar cada vez mais importante na citricultura brasileira, com sua exportação em ascensão, além do consumo no mercado interno. Trata-se de uma variedade que satisfaz plenamente as exigências do mercado consumidor, quanto à qualidade do suco, ao sabor, ao tamanho do fruto e à ausência de sementes (Barros et al., 1991). Porém, a lima ácida 'Tahiti' apresenta peculiaridades quanto à sua comercialização, se comparada com outras frutas cítricas, pois é uma fruta que apresenta redução na aceitação após a perda da coloração verde da casca. O aparecimento da coloração amarela, total ou parcialmente, reduz sua aceitação pelo mercado consumidor, tanto interno quanto externo (Manfroi et al., 1996).

A refrigeração tem sido a técnica pós-colheita mais utilizada para a preservação de frutas frescas, considerando que ela reduz o metabolismo, diminui a perda de peso, retarda o desenvolvimento de patógenos causadores de podridões e atrasa a senescência (Hardenburg et al., 1986; Chitarra \& Chitarra, 1990). Entretanto, dada à sensibilidade dos citros à baixa temperatura, o seu armazenamento por longos períodos é dificultado, considerando que, invariavelmente, os sintomas de injúrias pelo frio surgem durante a fase de comercialização, após a retirada do produto da condição refrigerada. 
As injúrias pelo frio constituem as desordens fisiológicas mais comuns e preocupantes em produtos hortícolas armazenados. Elas ocorrem quando os produtos são expostos a temperaturas inferiores a temperatura mínima de segurança (TMS), mas acima do ponto de congelamento. A TMS é variável para os diferentes produtos, variando de 0 a $15^{\circ} \mathrm{C}$, e define a temperatura abaixo da qual os danos podem ocorrer, dependendo do tempo de exposição (Chitarra \& Chitarra, 1990; Wang, 1994; Kluge et al., 2001). Para controlar o desenvolvimento de injúrias pelo frio, tratamentos térmicos têm sido testados. $O$ efeito destes tratamentos tem sido creditado ao estímulo na síntese de poliaminas e proteínas de choque de calor (HSP) e à manutenção da atividade de enzimas antioxidativas (removedoras de radicais livres). Estas respostas fazem com que os frutos suportem as baixas temperaturas por mais tempo.

As condições recomendadas para a conservação refrigerada de lima ácida 'Tahiti' são temperatura entre 10 e $12^{\circ} \mathrm{C}$ e umidade relativa (UR) entre $85-95 \%$. Sob tais condições os frutos podem ser armazenados por 4 a 8 semanas. Longos períodos de temperatura abaixo de $8^{\circ} \mathrm{C}$ induzem o aparecimento de injúrias pelo frio, caracterizadas por depressões superficiais e aumento na incidência de doenças (Hardenburg et al., 1986; Chitarra e Chitarra, 1990; Kader e Arpaia, 1992; Kluge et al., 2001).

Os frutos cítricos são considerados não climatéricos e produzem pequena quantidade de etileno. Entretanto, aplicação de etileno e, possivelmente, o etileno endógeno, pode estar envolvido na regulação da maturação e senescência dos frutos (Porat et al., 1999). Aplicações de etileno ou geradores de etileno são utilizadas para acelerar o desverdecimento da casca. O etileno, neste caso, atua sinalizando para o aumento na síntese de proteínas, particularmente aumentando a síntese 
da enzima clorofilase, enzima-chave no processo de degradação da clorofila (Kurata et al., 1999).

Alguns autores apontam que o etileno pode aumentar a severidade das injúrias pelo frio em frutos, enquanto outros argumentam que uma pequena quantidade de etileno é requerida para manter a atividade de enzimas antioxidativas.

O objetivo do presente projeto é verificar se o etileno e os tratamentos térmicos influenciam no desenvolvimento de mecanismos de resistência dos frutos à baixa temperatura, através da determinação da relação entre a sua produção e os níveis de poliaminas, bem como a atividade de enzimas antioxidativas. Serão utilizados tratamentos que estimulam a produção de etileno, tratamentos que bloqueiam a sua produção e/ou ação e tratamentos térmicos. Com estes estudos será possivel verificar o mecanismo primário para a obtenção de resistência dos frutos às baixas temperaturas de armazenamento e, assim, contribuir para a obtenção de informações básicas para o desenvolvimento de tecnologias ou adoção de tratamentos visando aumentar a conservabilidade de frutos cítricos em baixas temperaturas. 


\section{REVISÃO DE LITERATURA}

\subsection{Importância da cultura}

A lima ácida 'Tahiti' (Citrus latifolia Tanaka), mais conhecida como limão 'Tahiti', é uma fruteira de origem tropical e exploração econômica bastante recente. Tornou-se conhecida na Califórnia, Estados Unidos, sendo introduzida no Brasil como forma de substituição do limão galego (Citrus aurantifolia), que é sensivel ao cancro e à tristeza dos citros, em que teve bastante aceitação do consumidor por ter composição do suco, óleo da casca e sua conformação muito semelhante ao do limão (Morão, 1997).

A produção de lima ácida 'Tahiti' vem crescendo e ocupando lugar cada vez mais importante na citricultura brasileira, com sua exportação em ascensão, além do consumo interno, visto tratar-se de uma variedade que satisfaz plenamente as exigências do mercado consumidor, quanto à qualidade do suco, ao sabor, ao tamanho do fruto e à ausência de sementes (Barros et al., 1991).

O Brasil produziu no ano de 2002, 984.551 toneladas de lima ácida, onde o Estado de São Paulo deteve 70\% desta produção (FNP Consultoria \& Comércio, 2005). Segundo Coelho (1993), no Brasil, a lima ácida 'Tahiti' destaca-se entre os frutos cítricos de maior importância comercial. Figueiredo et al. (2001) acrescentam que a cultura vem despertando grande interesse para a ampliação dos plantios comerciais, em função do seu bom comportamento em relação às 
principais doenças e pragas que estão presentes nos pomares de citros e têm causado grandes prejuízos aos produtores de laranja doce. O interesse também cresce, segundo esses autores, pelo incremento dos países importadores de frutos cítricos por essa fruta, que segundo Donadio (1999) ainda é considerada exótica em muitos países. Estanislau et al. (2001) relataram que, nos últimos cinco anos, o Brasil praticamente dobrou suas exportações de limas e limões devido à crescente aceitação dessas frutas pelos consumidores europeus, antes acostumados com o consumo dos limões verdadeiros.

A colheita de lima ácida 'Tahiti' alcança seu pico nos meses de abril a maio, época em que seu preço no mercado alcança um mínimo, não compensando sequer as despesas de colheita e transporte. As maiores preocupações dos produtores são o abastecimento do mercado na entressafra e o tempo de transporte para a exportação da fruta (Mizobutsi et al., 2000).

Na prática, esta fruta é colhida com coloração verde, após alcançar o pleno desenvolvimento, e comercializada enquanto a cor da casca permanece nesta condição. Entretanto, os processos de degradação da clorofila e síntese de carotenóides continuam ocorrendo mesmo durante a comercialização sob condições ambientais, e culminam com o desverdecimento da fruta, o que é prejudicial para a comercialização (Baldwin, 1994).

\subsection{Injúria pelo Frio e Métodos de Controle}

A refrigeração tem sido a principal técnica utilizada para preservar a qualidade dos produtos hortifrutícolas recém colhidos. Para as frutas cítricas, o controle de podridões é um dos aspectos de maior importância no mercado de frutas destinadas ao consumo in natura. Neste aspecto, o uso de baixa temperatura de armazenamento é 
importante no sentido de retardar o desenvolvimento de podridões e prolongar o período de oferta de citros no mercado. Entretanto, dada à sensibilidade dos citros à baixa temperatura, o seu armazenamento por longos períodos é dificultado, considerando que, invariavelmente, os sintomas de injúrias pelo frio surgem durante a fase de comercialização, após a retirada do produto na condição refrigerada. Segundo Inzé \& Van Montague (1995), temperaturas extremas podem ser muito estressante para plantas, resultando em um estresse oxidativo, ou seja, formação de espécies ativas de oxigênio (superóxido e peróxido de hidrogênio), que são danosos à célula, pois o peróxido de hidrogênio é uma molécula permeável a membrana acarretando em morte celular. Essa molécula se destaca como um sinalizador intercelular de estresse, (Prasad et al. 1994).

A maioria das frutas e vegetais de origem tropical e subtropical é sensivel às baixas temperaturas. A exposição destes produtos em temperatura abaixo da faixa de 10 a $15^{\circ} \mathrm{C}$ e superiores a ponto de congelamento podem produzir diferentes danos (Chitarra \& Chitarra, 1990). Na referida faixa de temperatura, o tecido vegetal se debilita, devido à alteração dos processos metabólicos normais. Em resposta ao estresse pelo frio, diversos sintomas são evidenciados, tais como lesões superficiais, manchas, descoloração interna e maturação anormal. Além disso, os produtos injuriados pelo frio são mais suscetiveis aos patógenos causadores de podridões e, assim, apresentam rápida deterioração (Wang, 1994).

As respostas primárias de frutos injuriados pelas baixas temperaturas têm sido consideradas como de natureza física, incluindo fenômenos de alteração na porção lipídica das membranas e disfunções das proteínas e enzimas ligadas às mesmas. Essas alterações conduzem a diversas conseqüências indesejáveis no metabolismo e ao 
desenvolvimento de sintomas que depreciam a qualidade do produto armazenado (Wang, 1993; Kluge et al., 2001). Essa alteração na porção lipídica tem sido atribuída a peroxidação lipídica (Du \& Bramlage, 1995), acarretando na desestruturação da membrana, aumentando a permeabilidade aos solutos e, conseqüentemente, danificando a célula.

As frutas cítricas, em geral, são sensiveis a baixas temperaturas, cujo sintoma se manifestam através da formação de depressões superficiais (pitting surface), aparecimento de manchas circulares e deprimidas de coloração marrom, e alterações no sabor e aroma. As injúrias pelo frio ocorrem durante o armazenamento sob temperatura abaixo da mínima de segurança (TMS) e os sintomas se manifestam, normalmente, durante a exposição à temperatura ambiente, na comercialização (Chitarra \& Chitarra, 1990; Schirra et al., 1997).

As condições ideais para a conservação de lima ácida 'Tahiti' são temperatura entre 10 a $12^{\circ} \mathrm{C}$ e umidade relativa (UR) entre 85 a $95 \%$. Sob tais condições os frutos podem ser armazenados por 4 a 8 semanas. Longos períodos de temperatura abaixo de $8^{\circ} \mathrm{C}$ induzem o aparecimento de injúrias pelo frio, caracterizadas por depressões superficiais e aumento na incidência de doenças (Hardenburg et al., 1986; Chitarra \& Chitarra, 1990; Kader \& Arpaia, 1992; Kluge et al., 2001).

A lima ácida 'Tahiti' apresenta peculiaridades quanto à sua comercialização, se comparada com as frutas cítricas. Entre elas, a manutenção da cor verde da casca, que é extremamente desejável durante toda a vida útil pós-colheita desta fruta. O aparecimento da coloração amarela, total ou parcialmente, ou o aparecimento de manchas (danos pelo frio), reduzem a aceitação pelo mercado consumidor.

Atualmente não existe nenhum método capaz de evitar completamente os danos de frio. O método básico de controle consiste 
no armazenamento dos produtos em temperaturas adequadas, ou seja, acima da TMS. Porém, este procedimento pode não ser eficaz para longos períodos de armazenamento, situação em que os sintomas de injúrias pelo frio também podem se manifestar (Kluge et al., 2001). Assim, outras alternativas vêm sendo testadas visando diminuir ou aliviar os danos de frio. As técnicas utilizadas reduzem os danos através do retardamento no desenvolvimento dos sintomas ou pelo aumento da tolerância do produto ao frio. Dentre estas técnicas destacam-se os tratamentos térmicos, aplicados antes da refrigeração na forma de condicionamento, ou durante o armazenamento refrigerado, na forma de aquecimento intermitente.

Embora altas temperaturas têm sido identificadas como agente causal do estresse oxidativo, tratamentos térmicos são utilizados para desinfestação e desinfecção, resultando em produção de proteínas de choque de calor (HSPs) e outras modificações que são benéficas para o produto hortícola. Esses tratamentos alteram o metabolismo do fruto e aumentam a termotolerância, antes que aumentem os efeitos do estresse oxidativo ocasionado pelo frio (Lurie, 1998).

O condicionamento térmico consiste em expor os frutos a temperaturas moderadas $\left(15-20^{\circ} \mathrm{C}\right)$ ou elevadas $\left(35-60^{\circ} \mathrm{C}\right)$, por curtos períodos, antes de refrigerá-los. Esse tratamento pode ser aplicado através de um aquecimento rápido, por imersão em água quente por curto tempo (minutos), ou por aquecimento um pouco mais lento (horas) em temperatura mais moderada, em ar. Segundo Fallik (2004), o aquecimento rápido em água quente inibe o amadurecimento, reduz a incidência de podridões e injúria pelo frio em muitas frutas. Em frutas cítricas foi verificado que o condicionamento térmico reduz os danos causados pelas baixas temperaturas e diminui a incidência de podridões (Ben-Yehoshua et al., 1987; Del Rio et al., 1992; Schirra \& Mulas, 1993; 
Rodov et al., 1995 e 2000; Gonzalez -Aguilar et al., 1997 e 1998; Porat et al., 1999; Plaza et al., 2004; Schirra et al. 2005).

O aquecimento intermitente consiste na interrupção da baixa temperatura de armazenamento, por um ou mais períodos de alta ou moderada temperatura. Esse tratamento deve ser realizado antes dos danos tornarem-se irreversíveis, o que varia de acordo com o produto (Kluge et al., 2001). Foi verificada eficiência no controle de injúrias pelo frio com a aplicação do aquecimento intermitente em algumas frutas cítricas (Cohen, 1988; Schirra \& Mulas, 1995; Schirra \& Cohen; 1999), e especificamente em lima ácida 'Tahiti’ (Kluge et al., 2003).

Os tratamentos térmicos podem, além de incrementar a tolerância do produto às baixas temperaturas, possibilitar o armazenamento em temperatura mais baixa daquela normalmente recomendada, possibilitando assim um maior benefício do frio na conservação da fruta (Schirra et al., 2004). Porém não se sabe qual é o mecanismo que está envolvido no aumento da tolerância dos frutos submetidos ao tratamento térmico. Alguns autores evidenciam que esses tratamentos aumentam o teor de poliaminas, que são agentes antesenescentes (Faust \& Wang, 1992; Barrachina et al., 2000; Valero et al., 2002). Outros verificaram que os tratamentos térmicos aumentaram a atividade das enzimas removedoras de radicais livres, as enzimas antioxidantes (Sala \& Lafuente, 1999 e 2000).

\subsection{Mecanismo de defesa da planta}

\subsubsection{Poliaminas}

As poliaminas são compostos nitrogenados e participam dos processos de crescimento e desenvolvimento de diversos órgãos das plantas, como flores, folhas e raízes. Contudo, o comportamento das 
poliaminas em frutos é diferente que nos demais órgãos. As concentrações de poliaminas mudam durante o processo de desenvolvimento e maturação dos frutos, onde o modelo da variação depende do tipo de fruto e estádio de maturação. As poliaminas estão relacionadas com vários tipos de estresse, incluindo danos por frio durante a conservação, estresse salino, conservação em atmosfera modificada e estresse mecânico, entre outros. No entanto, não se conhece com certeza se o aumento de poliaminas é um mecanismo de proteção ou se é a causa do estresse induzido pelo dano (Barrachina et al., 2000).

O termo poliamina tem sido usado na literatura tanto na sentido genérico para incluir putrescina, espermidina, espermina, outras aminas e vários compostos derivados, como no sentido restrito, significando apenas aminas primárias que apresentam dois ou mais de dois grupos amina, tais como a putrescina, a espermidina e a espermina (Evans \& Malmberg, 1989).

A sintese de poliaminas a partir de arginina e ornitina, via ornitina descarboxilase e arginina descarboxilase possui duas vias metabólicas para a sintese de putrescina. Essas duas vias apresentam distribuições em tecidos diferentes e diferentes regulações. A arginina descarboxilase está associada à resposta ao estresse, enquanto a ornitina descarboxilase associa-se ao ciclo celular e à divisão celular. Uma via inclui a transformação de arginina em ornitina, e outra rota implica a descarboxilação da arginina para formar agmatina e sua posterior transformação em putrescina. Por último, a putrescina é convertida à espermidina e espermina, por sucessivas transferências de 1 ou 2 grupos amino propil via descarboxilação do S-adenosil metionina (SAM), que é um composto muito importante no metabolismo do $\mathrm{N}_{2}$ e é, além disso, precursor do etileno (Faust \& Wang, 1992). 
Como já mencionado, o dano pelo frio é caracterizado pela formação de radicais livres na célula vegetal, que são tóxicos, levando desestruturação das membranas celulares e a morte dos tecidos. O papel das poliaminas na célula vegetal é de agente antisenescente. Devido a sua natureza policatiônica, as poliaminas tem grande afinidade por constituintes aniônicos como DNA, RNA, fosfolipídios e proteínas, bem como grupos aniônicos das membranas e paredes celulares. Essa característica confere maior estabilidade às membranas, protegendo-as contra a peroxidação (Wang, 1993; Artés, 1995; Tatsumi et al., 1995), ao DNA e RNA, protegendo as células contra o dano de frio, pois são capazes de se ligarem a radicais livres (Galston \& Kaur-Sawhney, 1987; Serrano et al., 1996).

Em termos de adaptação à condição de estresse pelo frio, há correlação direta com o aumento dos níveis de espermidina e espermina (Kramer \& Wang, 1989). Esses resultados indicam que as poliaminas podem estar envolvidas na proteção dos tecidos de plantas contra o frio e são consistentes com a sugestão de que os compostos aumentam a viabilidade das células durante o frio por retardarem a senescência das membranas (Guye et al., 1986; McDonald \& Kushad, 1986).

Os mecanismos de ação dos tratamentos térmicos são pouco conhecidos. Lurie \& Klein (1990 e 1991) observaram que o condicionamento térmico induziu a produção de HSP, que parecem estar envolvidas no processo de termotolerância. Hewett (2000) comenta que, embora esteja comprovada a produção de proteínas de choque de calor, esta não constitui a única resposta dos produtos submetidos aos tratamentos térmicos e reforça a necessidade de pesquisas visando a exploração de outras respostas metabólicas, como forma de identificar pontos críticos que podem ser possíveis de manipulação. 
Tem sido proposto que tratamentos térmicos podem provocar um aumento de poliaminas (putrescina, espermidina e espermina), cuja biossintese é estimulada sob diferentes condições de estresse (Faust \& Wang, 1992; Barrachina et al., 2000).

Gonzales-Aguilar et al. (1997) verificaram que tangerinas 'Fortune' aquecidas em temperaturas entre 47 e $60^{\circ} \mathrm{C}$, por 3 minutos, apresentaram maiores níveis de poliaminas no flavedo, estando isso relacionado com a menor incidência de injúrias pelo frio durante o armazenamento a 2C. Similarmente, Gonzales-Aguilar et al. (1998) condicionaram a mesma variedade a $37^{\circ} \mathrm{C}$ por 2 ou 3 dias e obtiveram aumento no conteúdo de poliaminas durante o armazenamento a $2^{\circ} \mathrm{C}$, o que reduziu a incidência de injúrias pelo frio.

\subsubsection{Enzimas antioxidantes}

Durante condições normais de crescimento e desenvolvimento, as plantas são invariavelmente expostas a diversas formas de estresses, tais como seca, calor, resfriamento, poluentes, radiação UV entre outros. Espécies reativas de oxigênio (AOS) são comumente formadas sob essas condições (Rao et al., 1996).

O oxigênio na atmosfera é relativamente não reativo, mas quando em contato com sistemas metabólicos, pode ser transformado em formas reativas, como superóxido $\left(\mathrm{O}_{2}^{-}\right)$, peróxido de hidrogênio $\left(\mathrm{H}_{2} \mathrm{O}_{2}\right)$, radicais hidroxila $\left(\mathrm{OH}^{-}\right)$e oxigênio singleto $\left({ }^{1} \mathrm{O}_{2}\right)$, as quais podem potencialmente causar danos ao ambiente celular (Sminorff, 1993), ou seja, danos em lipídios de membrana afetando a sua permeabilidade (Chevrier et al., 1988), proteínas, clorofila e ácidos nucléicos (Scandalios, 1993; Foyer et al., 1994). Estas formas de oxigênio são freqüentemente chamadas de oxigênio ativo. O termo radical livre de oxigênio também é utilizado coletivamente, embora somente o superóxido e radicais hidroxilas sejam 
realmente radicais livres. Algumas dessas AOS podem formar radicais livres orgânicos, os quais podem interagir com um grande número de moléculas causando danos. Por esta razão, as células de organismos aeróbicos possuem diversos mecanismos para remover essas AOS antes que causem danos ou para repará-los quando ocorrem (Smirnoff, 1993).

$\mathrm{O}$ estresse por baixa temperatura favorece a formação de radicais livres. As principais AOS são o superóxido e peróxido de hidrogênio. As AOS desempenham papel significante na peroxidação lipídica (Zheng \& Yang, 1991; Delong \& Steffen, 1998), quebra de polissacarídeos (Monk et al., 1989), além da degradação de ácidos nucléicos (Becana et al., 1998) e proteínas (Iturbe-Ormaetxe et al., 1998).

A formação de superóxido e peróxido de hidrogênio $\left(\mathrm{H}_{2} \mathrm{O}_{2}\right)$ nos tecidos expostos à baixa temperatura pode causar a peroxidação dos lipídios da membrana, afetando a sua integridade e permeabilidade, levando à morte celular (Purvis \& Shewfelt, 1993; Wang, 1995; Sala, 1998).

Nas plantas existem um complexo sistema antioxidante que protegem contra os altos níveis das AOS, o qual incluem três classes: sistema lipossolúvel (antioxidantes associados a membrana - $\alpha$ tocopherol, e $\beta$-caroteno), sistema hidrossolúvel (glutationa e ascorbato), e, por fim, o sistema enzimático, o qial inclui a Superóxido Dismutase [SOD, EC 1.15.1.1], Catalase [CAT, EC 1.11.1.6] e Peroxidase [POD, EC 1.11.1.7]. Existem também outros antioxidantes que ocorrem naturalmente na planta, tais como isoflavina, fenol, poliamina a aminoácidos específicos, como cisteína e metionina (Larson, 1988; Levine et al., 1996; Robards et al., 1999).

Esse sistema enzimático antioxidante tem a associação de várias enzimas, sendo eficiente na remoção de radicais livres. A SOD é a primeira enzima de defesa contra os danos provocados pelas AOS nas 
células (Alscher et al., 1997). Sob essa denominação agrupa-se um grupo de metaloenzimas que catalisam a dismutação de radicais livres de oxigênio $\mathrm{O}_{2}^{-}$a peróxido de hidrogênio (Scandalios, 1993). Esse peróxido, por sua vez, é catalisado pela CAT a água e oxigênio (Willekens et al., 1995). Outra enzima chave é o Ascorbato Peroxidase [APX, EC 1.11.1.11], que remove também o peróxido de hidrogênio formado, transformando em água e oxigênio. Radicais monodesidroascorbato produzidos pela APX são convertidos a ascorbato (AsA) via ferredoxina ou pela enzima Monodesidroascorbato Redutase (MDHAR). Uma outra alternativa da reação com APX é a formação de ácido ascórbico e ácido desidroascorbato, que podem ser convertidos a ascorbato através da enzima Desidroascorbato Redutase (DHAR), que utiliza a glutationa como doador de elétrons. A subseqüente regeneração da glutationa requer a participação de outra enzima chave, a Glutationa Redutase [GR, EC 1.6.4.2], e de NADPH (Allen et al., 1995).

Resumindo, o papel central no mecanismo antioxidante em plantas é desempenhado pela SOD, sendo o produto de sua reação quebrado pela CAT ou outras peroxidases como APX e guaiacol peroxidase (GP), conforme Figura 1. Outras enzimas como GR, DHAR e MDHAR também estão envolvidas na remoção das espécies reativas de oxigênio (Allen, 1995). Portanto, a remoção desses radicais livres envolve a interação de enzimas protetoras, antioxidantes de baixo peso molecular e seus sistemas de regeneração (Foyer et al., 1994). 


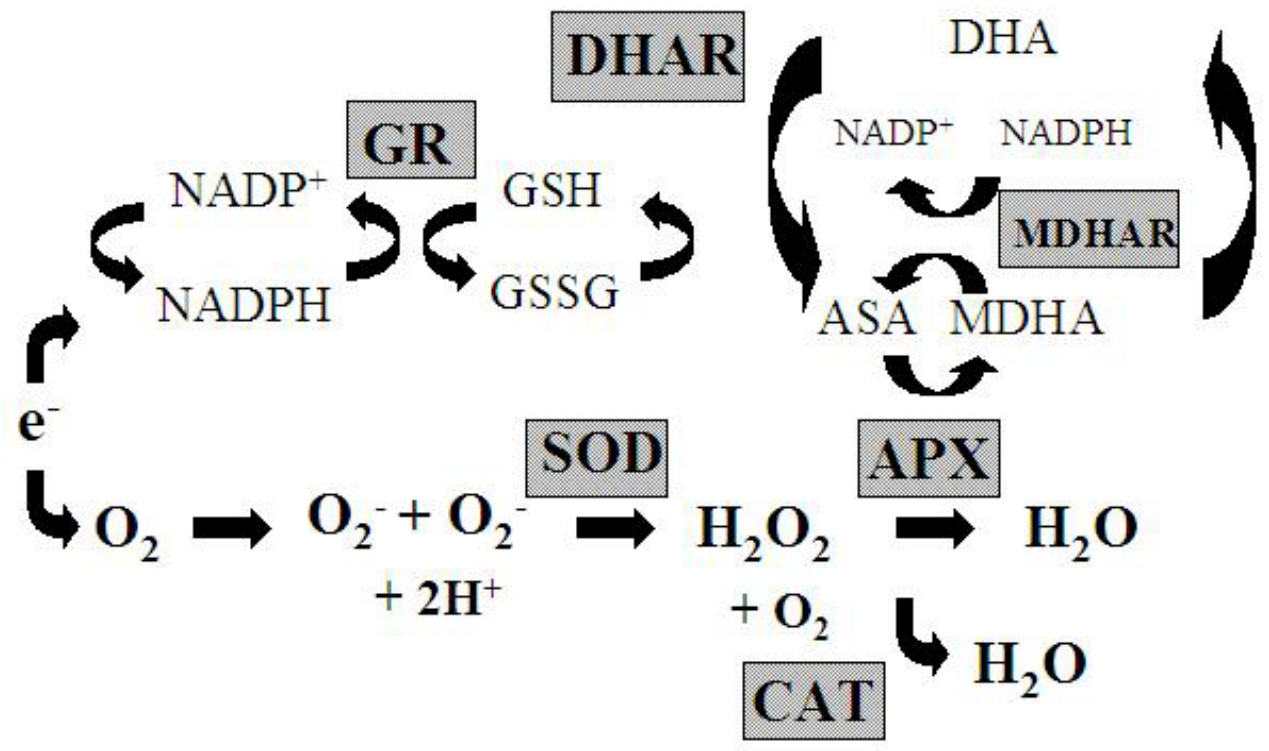

Figura 1 - Esquema da via de remoção das espécies ativas de oxigênio (Adaptado de Fornazier, 2000)

Sala (1998) comenta que frutos que possuem alta capacidade de metabolizar o peróxido de hidrogênio $\left(\mathrm{H}_{2} \mathrm{O}_{2}\right)$ são mais resistentes à baixa temperatura. Descreve o autor que esta metabolização ocorre através da atividade da enzima catalase (CAT), auxiliada pela ascorbato peroxidase (APX), glutationa redutase (GR) e superoxido dismutase (SOD). Este autor verificou que tangerinas 'Clementina' são menos sensíveis à baixa temperatura de armazenamento, pois apresentam um sistema antioxidante mais eficiente, mantendo alta a atividade da CAT, APX e GR durante o armazenamento sob baixa temperatura $\left(2,5^{\circ} \mathrm{C}\right)$.

Os tratamentos térmicos podem ser utilizados para evitar a redução na atividade das enzimas removedoras de radicais livres, como verificado em alguns trabalhos. Wang et al. (1995) observaram que o condicionamento de abobrinhas durante 2 dias a $15^{\circ} \mathrm{C}$ manteve a atividade da CAT e SOD e reduziu o desenvolvimento das injúrias pelo frio durante o armazenamento a $5^{\circ} \mathrm{C}$. Sala \& Lafuente (1999) 
encontraram aumento na atividade da CAT, SOD e APX em tangerinas 'Fortune' que sofreram aquecimento durante 3 dias a $37^{\circ} \mathrm{C}$ antes do armazenamento em temperatura indutora de chilling $\left(2^{\circ} \mathrm{C}\right)$. Este tratamento reduziu significativamente o desenvolvimento das injúrias pelo frio nos frutos. Recentemente, Sala \& Lafuente (2000) observaram que a CAT parece ser a principal enzima antioxidativa envolvida no mecanismo de defesa de tangerinas contra as injúrias pelo frio.

O envolvimento do etileno com a atividade das enzimas removedoras de radicais livres tem sido pouco estudado. Masia (1998) verificou, em maçãs, que a elevação na atividade da CAT e SOD ocorreu concomitantemente com o aumento na produção de etileno em frutos ligados à planta ou armazenados sob refrigeração. Segundo Sala \& Lafuente (2004), as atividades de SOD, CAT, GR e APX aumentaram durante o armazenamento refrigerado de frutos de laranjas 'Navelina', em baixa umidade, enquanto GR pode estar envolvido no efeito benéfico do etileno em reduzir o dano pelo frio.

Recentemente, Srivastava \& Dwivedi (2000) verificaram que a aplicação de ácido salicílico reduziu a atividade da CAT em bananas. O ácido salicílico é um inibidor da ACC oxidase, a enzima formadora do etileno (Jun et al., 1999). Assim, é possivel que o etileno esteja envolvido na ativação destas enzimas antioxidativas e, portanto, com os mecanismos de defesa dos frutos contra as injúrias pelo frio.

\subsection{Etileno}

O etileno $\left(\mathrm{C}_{2} \mathrm{H}_{4}\right)$ é um hormônio vegetal que controla muitos aspectos do crescimento e desenvolvimento das plantas (Yang \& Hoffmann, 1984). O etileno é sintetizado naturalmente durante estágios específicos de desenvolvimento, tais como na germinação de sementes, na senescência e abscisão de folhas e flores e no crescimento de folhas e 
raízes, no caso especificamente de frutos, está envolvido na aceleração do amadurecimento e senescência dos mesmos. Este fitohormônio tem como precursor primário o SAM (S-adenosilmetionina) e como intermediário a ACC (ácido aminociclopropano carboxílico). A enzima ACC sintase catalisa a reação de formação do ACC a partir de SAM, e a enzima ACC oxidase oxida o ACC formando etileno (Abeles et al., 1992).

O mecanismo de ação do etileno consiste na sua ligação a uma molécula receptora, provavelmente uma proteína (ETR1), que possui um sítio de ligação do hormônio. A ativação do mesmo segue através de dois passos possíveis: o próprio receptor ativa o fitohormônio ou, o que parece mais provável, uma via de sinalização formada por mensageiros secundários vão ao núcleo da célula e induzem a expressão gênica (transcrição). Conseqüentemente há formação de novos RNAs e novas proteínas, desencadeando uma série de respostas inerentes ao etileno, como o amadurecimento e senescência dos frutos (Burg \& Burg, 1967; Lelièvre et al., 1997). Segundo Grierson et al. (1987), o etileno promove a senescência, estimula a respiração, produção de voláteis e aumenta a suscetibilidade à deterioração.

A produção de etileno pode ser incrementada por vários tipos de estresse, incluindo danos mecânicos, temperatura (resfriamento, congelamento e, ocasionalmente, alta temperatura) e produtos químicos (auxinas, herbicidas e vários poluentes). O etileno também se acumula nos tecidos das plantas em resposta às infecções patogênicas (Yang \& Hoffmann, 1984).

Em frutos climatéricos o etileno é considerado o elicitor do processo de amadurecimento e, uma vez aplicado no momento correto, torna o processo irreversível. Em frutos não climatéricos, a aplicação causa menor efeito, sendo que este pode ser revertido. Em nível comercial, aplicação de etileno ou geradores de etileno em citros têm 
sido realizados com o objetivo de promover o desverdecimento da casca dos frutos, estando este efeito relacionado com o aumento na atividade da enzima clorofilase.

O envolvimento do etileno sobre a manifestação de injúrias pelo frio em frutos ainda é objeto de estudo. Por exemplo, abacates tratados com etileno ou expostos ao hormônio apresentaram mais desenvolvimento de injúrias pelo frio do que frutos não tratados ou não expostos (Chaplin et al., 1983; Lee \& Young, 1984). Yuen et al. (1995) observaram que a aplicação de etileno $\left(0,005\right.$ a $\left.10 \mu \mathrm{L} \mathrm{L}^{-1}\right)$ em lima 'Tahiti', tangerina 'Emperor', pomelo 'Marsh' e laranja 'Valência' resultaram em aumento nas injúrias pelo frio nos frutos armazenados a $0^{\circ} \mathrm{C}$, assim como verificado por Brown \& Lee (1993). Em laranjas 'Shamouti' foi verificado que a aplicação de etileno antes do armazenamento refrigerado aumentou a incidência de danos pelo frio nos frutos (Porat et al., 1999). Por outro lado, tem sido observado também que o etileno pode aliviar as injúrias pelo frio, como em melões 'Honeydew' (Lipton \& Aharoni, 1979) e em batata doce (Buescher, 1977), ou não afetar o desenvolvimento das injúrias, como observado em tomates (Kader \& Morris, 1975).

$\mathrm{O}$ aquecimento dos frutos antes ou durante o armazenamento refrigerado pode provocar aumento ou redução na síntese de etileno, dependendo da temperatura utilizada. Conforme Abeles et al. (1992), a temperatura ótima para a produção de etileno situa-se entre 28 e $30^{\circ} \mathrm{C}$. Temperaturas acima de $30^{\circ} \mathrm{C}$ podem reduzir a produção de etileno, devido a inativação temporária da ACC sintase e ACC oxidase, enzimaschave da biossintese do etileno. Entretanto, tem sido pouco determinado o efeito dos tratamentos térmicos sobre a produção de etileno e sua relação com a manifestação das injúrias pelo frio. 


\subsubsection{Bloqueadores da produção e ação do etileno}

Produtos bloqueadores da síntese e ação do etileno têm sido testados em frutos com o objetivo de retardar o amadurecimento e a senescência. Estes produtos incluem o ácido salicílico, que é um efetivo bloqueador da síntese de etileno. O ácido salicílico inibe a atividade da enzima ACC oxidase, que converte o ACC em etileno (Abeles et al., 1997). Quando aplicada, o ácido salicílico reduz a produção autocatalítica de etileno e parece diminuir a produção de etileno causada por estresses. O SAM, que o principal doador de grupos metil em plantas superiores, é também um produto intermediário da biossíntese de poliaminas e até o presente não foi determinado se o acúmulo de SAM promove um desvio na rota biossintética do etileno para a síntese de poliaminas.

O 1-metilciclopropeno (1-MCP) é um composto gasoso que tem demonstrado ser um eficiente inibidor da ação do etileno (Serek et al., 1995). O 1-MCP age através da fixação preferencial ao sítio receptor do etileno, atuando como antagonista, bloqueando, desse modo, os efeitos do etileno procedentes de fontes internas e externas. Provavelmente, essa preferência ao receptor é devido ao baixo $\mathrm{KM}$ do 1-MCP $\left(17 \mathrm{~nL} \mathrm{~L}^{-1}\right)$ em comparação com $96 \mathrm{~nL} \mathrm{~L}^{-1}$ do etileno, demonstrando sua maior afinidade aos receptores de etileno (Jiang et al., 1999a). O 1-MCP se liga de maneira irreversivel, sendo que o posterior amadurecimento do fruto é devido à formação de novos receptores de etileno (Feng et al., 2000; Jiang et al., 1999b; Sisler et al., 1996).

Foi verificado, em experimentos, que o 1-MCP retardou o amadurecimento de frutos climatéricos, como pêra (Lelièvre et al., 1997), maçã (Fan et al., 1999), banana (Jiang et al., 1999b), ameixa (Abdi et al., 1998), tomate (Sisler \& Serek, 1997) e damasco (Fan et al., 2000). 
O bloqueio na produção e ação do etileno e sua interação com o desenvolvimento de injúrias pelo frio em frutos têm sido pouco estudado. Ben-Amor et al. (1999) demonstraram que a supressão na produção de etileno, através de antisense ACC oxidase, reduziu a sensitividade de melões cantaloupe às baixas temperaturas, assim como em pêssegos 'Rojo Brilhante' (Salvador et al., 2004). Outros autores também verificaram que os danos de frio foram reduzidos com a aplicação de 1-MCP em frutos de abacate, abacaxi e ameixa (Selvarajah et al., 2001; Pesis et al., 2002; Salvador et al., 2003).

Por outro lado, Porat et al. (1999), trabalhando com laranjas 'Shamouti', verificaram que o bloqueio da ação do etileno com 1-MCP aumentou os danos pelas baixas temperaturas. Os autores concluíram que pequena produção de etileno é necessária para a manutenção dos mecanismos de defesa dos frutos contra estresses fisiológicos e patológicos. 


\section{TRATAMENTOS TÉRMICOS COMO FORMA DE AUMENTAR A RESISTÊNCIA DE LIMA ÁCIDA 'TAHITI' A BAIXA TEMPERATURA}

\section{Resumo}

Frutos de lima ácida 'Tahiti' foram submetidos a tratamentos térmicos para avaliar o desenvolvimento da resistência a baixa temperatura. Esses tratamentos térmicos consistiram em condicionamento rápido, por 2 horas a $53^{\circ} \mathrm{C}$, condicionamento lento, por 48 horas a $37^{\circ} \mathrm{C}$ e aquecimento intermitente, ciclo de 6 dias a $1^{\circ} \mathrm{C}$ e 1 dia a $25^{\circ} \mathrm{C}$ seguindo-se do armazenamento dos frutos a $1{ }^{\circ} \mathrm{C}$ durante 45 dias. O delineamento experimental foi inteiramente ao acaso com 4 repetições de 10 frutos por parcela por tratamento. Foram determinadas a incidência de injúrias pelo frio, a taxa de produção de etileno e taxa respiratória, os níveis de poliaminas, a atividade de enzimas antioxidativas, além das determinações tecnológicas. Verificou que os frutos submetidos ao aquecimento intermitente aumentaram a resistência dos frutos à baixa temperatura, estando associado com as atividades das enzimas antioxidativas. Os frutos submetidos ao condicionamento térmico lento não diferiram dos frutos do controle. Já os frutos submetidos ao condicionamento rápido toleraram ao dano de frio somente até 15 dias de armazenamento.

Palavras-chave: Citrus latifolia Tanaka, injúria pelo frio, aquecimento intermitente, condicionamento térmico rápido e lento. 


\section{HEAT TREATMENT AS FORM TO INCREASE RESISTANCE OF 'TAHITI' LIME AT LOW TEMPERATURE}

\section{Summary}

Fruit of 'Tahiti' lime were submitted the heat treatments to evaluate the development of the resistance at low temperature. These treatments consisted of heat treatment in water at $53^{\circ} \mathrm{C}$ during $3 \mathrm{~min}$, heat treatment in air at $37^{\circ} \mathrm{C}$ during $48 \mathrm{~h}$, and intermittent warming with cycles of 6 days at $1^{\circ} \mathrm{C}+1$ day at $25^{\circ} \mathrm{C}$ following of cold storage at $1^{\circ} \mathrm{C}$ during 45 days. It was used the completely randomized design with 4 replicates for treatment, and 10 fruits in each replicate. Incidence of chilling injury, production of ethylene, respiratory rate, polyamines content, antioxidants enzymes activity and technological determination were evaluated. It was observed that fruit submitted to intermittent warming had increased the resistance at low temperature, might be associated with the activity of antioxidants enzymes. Fruit submitted to air heat treatment did not differed from control. Fruit submitted to water heat treatment showed resistance to chilling injury up to 15 days of cold storage.

Key words: Citrus latifolia Tanaka, chilling injury, intermittent warming, air heat treatment, water heat treatment.

\subsection{Introdução}

A lima ácida 'Tahiti' apresenta peculiaridades quanto à sua comercialização, se comparada com as demais frutas cítricas. Entre 
elas, a manutenção da cor verde da casca, que é extremamente desejável durante toda a vida útil pós-colheita desta fruta. O aparecimento da coloração amarela, total ou parcialmente, ou o aparecimento de manchas (danos pelo frio), reduzem a aceitação pelo mercado consumidor. As condições recomendadas para a conservação refrigerada de lima ácida 'Tahiti' são temperatura entre 10 a $12^{\circ} \mathrm{C}$ e umidade relativa (UR) entre $85-95 \%$. Sob tais condições os frutos podem ser armazenados por 4 a 8 semanas. Longos períodos de temperatura abaixo de $8^{\circ} \mathrm{C}$ induzem o aparecimento de injúrias pelo frio, caracterizadas por depressões superficiais e aumento na incidência de doenças (Hardenburg et al., 1986; Chitarra \& Chitarra, 1990; Kader \& Arpaia, 1992; Kluge et al., 2001).

A refrigeração tem sido a principal técnica utilizada para preservar a qualidade dos produtos hortifrutícolas recém colhidos. Para as frutas cítricas, o controle de podridões é um dos aspectos de maior importância no mercado de frutas destinadas ao consumo in natura. Neste aspecto, o uso de baixa temperatura de armazenamento é importante no sentido de retardar o desenvolvimento de podridões e prolongar o período de oferta de citros no mercado. Entretanto, dada à sensibilidade dos citros à baixa temperatura, o seu armazenamento por longos períodos é dificultado, considerando que, invariavelmente, os sintomas de injúrias pelo frio surgem durante a fase de comercialização, após a retirada do produto na condição refrigerada. Segundo Inzé \& Van Montague (1995), temperaturas extremas podem ser muito estressante para plantas, resultando em um estresse oxidativo, ou seja, formação de espécies ativas de oxigênio (superóxido e peróxido de hidrogênio), que são danosos à célula, pois o peróxido de hidrogênio é uma molécula permeável a membrana, acarretando em morte celular. Essa molécula se 
destaca como um sinalizador intercelular de estresse (Prasad et al. 1994).

Atualmente não existe nenhum método capaz de evitar completamente os danos de frio. O método básico de controle consiste no armazenamento dos produtos em temperaturas adequadas, ou seja, acima da temperatura crítica. Porém, este procedimento pode não ser eficaz para longos períodos de armazenamento, situação em que os sintomas de injúrias pelo frio também podem se manifestar (Kluge et al., 2001). Assim, outras alternativas vêm sendo testadas visando diminuir ou aliviar os danos de frio. As técnicas utilizadas reduzem os danos através do retardamento no desenvolvimento dos sintomas ou pelo aumento da tolerância do produto ao frio. Dentre estas técnicas destacam-se os tratamentos térmicos, aplicados antes da refrigeração na forma de condicionamento, ou durante o armazenamento refrigerado, na forma de aquecimento intermitente.

Os tratamentos térmicos podem, além de incrementar a tolerância do produto às baixas temperaturas, possibilitar o armazenamento em temperatura mais baixa daquela normalmente recomendada, possibilitando assim um maior benefício do frio na conservação da fruta (Schirra et al., 2004a). Porém não se sabe qual é o mecanismo que está envolvido no aumento da tolerância dos frutos submetidos ao tratamento térmico. Alguns autores evidenciam que esses tratamentos aumentam o teor de poliaminas, que são agentes antesenescentes (Faust \& Wang, 1992; Barrachina et al., 2000; Valero et al., 2002). Outros verificaram que os tratamentos térmicos aumentaram a atividade das enzimas removedoras de radicais livres, as enzimas antioxidantes (Sala \& Lafuente, 1999 e 2000). 
O objetivo deste trabalho foi verificar o efeito dos tratamentos térmicos no desenvolvimento do mecanismo de resistência dos frutos de lima ácida 'Tahiti’ à baixa temperatura.

\subsection{Material e Métodos}

Frutos de lima ácida 'Tahiti' foram colhidos em pomar comercial localizado no município de Mogi-Mirim, SP e transportadas ao Laboratório de Fisiologia Pós-colheita do Departamento de Ciências Biológicas da ESALQ/USP. Os frutos tinham a coloração verde-intensa, com diâmetro médio de $6 \mathrm{~cm}$ (Figura 2).

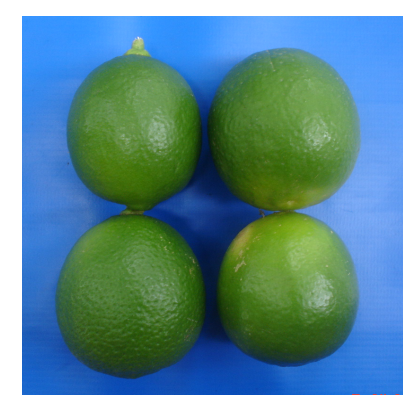

Figura 2 - Frutos de lima ácida 'Tahiti' antes do armazenamento refrigerado a $1^{\circ} \mathrm{C}$

\section{Tratamentos}

Os tratamentos constaram da aplicação de tratamentos térmicos, condicionamento e aquecimento intermitente.

Os tratamentos foram assim distribuídos:

Tratamento 1: Frutos sem tratamento e armazenados a $1^{\circ} \mathrm{C}$ (Controle). 
Tratamento 2: Aquecimento rápido dos frutos: os frutos foram aquecidos em água quente a $53^{\circ} \mathrm{C}$ durante 3 minutos e armazenados a $1^{\circ} \mathrm{C}$.

Tratamento 3: Aquecimento lento dos frutos: os frutos foram colocados em câmara regulada para $37^{\circ} \mathrm{C}$ onde ficaram por 2 dias. Após, foram armazenados a $1^{\circ} \mathrm{C}$.

Tratamento 4: Aquecimento intermitente: ciclos de 6 dias a $1^{\circ} \mathrm{C}+1$ dias a $25^{\circ} \mathrm{C}$.

Os frutos foram armazenados a $1{ }^{\circ} \mathrm{C}$ em câmaras frias do Departamento de Produção Vegetal (ESALQ/USP), por períodos de 15, 30 e 45 dias, sendo que após cada período de armazenamento, foram expostos à temperatura ambiente $\left(25^{\circ} \mathrm{C}\right)$ por 3 dias, para simular uma comercialização.

\section{Determinações}

1. Injúrias pelo frio

A incidência de injúrias pelo frio foi determinada de acordo com a metodologia adaptada de Sala \& Lafuente (1999). De acordo a superfície da casca afetada os frutos foram classificados em cinco categorias: $0=$ sem depressões superficiais ( $0 \%$ da superfície afetada), $1=$ pouco ( 1 a $5 \%$ da superfície afetada), $2=$ médio (5-25\%) e $3=$ severo $(25-50 \%)$ e $4=$ muito severo ( $>50 \%$ da superfície afetada).

\section{Produção de etileno}

Para a determinação da produção de etileno, os frutos foram colocados em frascos de vidro com capacidade de $500 \mathrm{~mL}$, preenchendo o espaço vazio com bolinha de vidro, permanecendo hermeticamente fechados por períodos de 2 horas. Em cada tampa dos jarros foi 
colocado um septo de borracha através do qual foi retirada a amostra de gás. Com uma seringa de $1 \mathrm{~mL}$ foi coletada uma amostra de cada jarro e injetada em cromatógrafo a gás. Os resultados foram expressos em $\mu \mathrm{L}$ $\mathrm{C}_{2} \mathrm{H}_{4} \mathrm{~kg}^{-1} \mathrm{~h}^{-1}$. Foram utilizados 1 fruto por frasco. Esta determinação foi realizada após a comercialização simulada de 3 dias a $25^{\circ} \mathrm{C}$.

\section{Taxa respiratória}

O procedimento foi semelhante ao anterior no que se refere à coleta da amostra de gás. A amostra foi injetada em cromatógrafo a gás. Os resultados foram expressos em $\mathrm{mg} \mathrm{CO} \mathrm{kg}^{-1} \mathrm{~h}^{-1}$.

\section{Análise de poliaminas}

As poliaminas foram determinadas seguindo a técnica modificada de Smith (1991) e Lima et al. (1999). Amostras previamente pesadas foram homogeneizadas em ácido perclórico $5 \%$ gelado $(100 \mathrm{mg} / \mathrm{mL})$, deixadas por 1 hora em banho de gelo e centrifugadas a $12000 \mathrm{G}$ por 20 minutos. O sobrenadante contendo poliaminas livres foi usado para dansilação. Cloreto de dansila (5-[diametilamino] naftaleno 1-sulfonil (cloreto)) - Sigma; $400 \mathrm{ml}$ de uma solução de $5 \mathrm{mg} / \mathrm{mL}$ acetona e $200 \mathrm{ml}$ de $\mathrm{Na}_{2} \mathrm{CO}_{3}$ saturado, foram adicionados a $200 \mathrm{ml}$ do sobrenadante. Após agitação, a mistura permaneceu em temperatura ambiente, no escuro, por 16 horas. As poliaminas foram extraídas com $500 \mathrm{ml}$ de benzeno e a fase orgânica foi usada para determinação por cromatografia de camada delgada, em placas recobertas por sílica gel 60G (Merck). Como fase móvel foi utilizada clorofórmio-trietilamina (25:2 v/v). Quantidades conhecidas de padrões de poliaminas foram dansiladas $\mathrm{e}$ cromatografadas da mesma maneira. A determinação quantitativa das poliaminas foi realizada em densitômetro (Helena). Os teores de 
poliaminas livres (putrescina, espermidina e espermina) foram expressos em $\mu g \mathrm{~g}^{-1}$ de massa fresca.

5. Determinação da atividade das enzimas antioxidativas

Foram determinadas as atividades das enzimas catalase, superóxido dismutase, ascorbato peroxidase e glutationa redutase.

Foi utilizado como material vegetal para a análise das enzimas a casca dos frutos, onde foi coletado somente tecido sadio, retirando as partes lesionadas. A coleta do material foi feita logo após a retirada dos frutos da câmara fria, aos 15 e 30 dias de armazenamento refrigerado, logo em seguida foram congelados em Nitrogênio líquido.

Os materiais vegetais foram macerados em nitrogênio líquido até a formação de uma farinha, logo em seguida foram homogeneizados em tampão (extração) fosfato de potássio $100 \mathrm{mM}(\mathrm{pH} 7,5)$ contendo $1 \mathrm{mM}$ de EDTA (0,372g/L tampão), 3mM de DTT (0,462g/L tampão) e 4\% (p/v) de PVPP.

O homogeneizado foi centrifugado a $10.000 \mathrm{rpm}$ por $30 \mathrm{~min}$ à $4^{\circ} \mathrm{C}$. O sobrenadante foi coletado, dividido em alíquotas e, estas, estocadas em freezer $-80^{\circ} \mathrm{C}$ até o momento das análises.

A análise das enzimas foi realizada por atividade em géis não denaturantes (poliacrilamida 8-10\%) e por espectrofotometria, dependendo da enzima e de acordo com a descrição que se segue.

Atividade da catalase - CAT (EC 1.11.1.6): a atividade da catalase foi determinada como descrito por Kraus et al. (1995) com algumas modificações de acordo com Azevedo et al. (1998). A CAT é determinada espectrofotometricamente a $25^{\circ} \mathrm{C}$ em uma mistura de reação contendo $1 \mathrm{~mL}$ de tampão fosfato de potássio (100 mM) pH 7,5 contendo $2,5 \mu \mathrm{L}$ de peróxido de hidrogênio (solução de 30\%) preparada imediatamente antes 
do uso. A reação foi iniciada pela adição de $15 \mu \mathrm{L}$ de extrato e a atividade foi determinada seguindo-se a decomposição de peróxido de hidrogênio por 1 min. Por alterações na absorbância a 240 ๆm.

Atividade da superóxido dismutase - SOD (EC 1.15.1.1): a atividade foi determinada por eletroforese, que foi conduzida à $4^{\circ} \mathrm{C}$ e, após a separação das proteínas, os géis foram enxaguados rapidamente em água destilada-deionizada e incubados no escuro a temperatura ambiente em uma mistura de reação contendo $50 \mathrm{mM}$ de tampão fosfato de potássio $\mathrm{pH}$ 7,8, $1 \mathrm{mM}$ EDTA, 0,05 $\mathrm{mM}$ riboflavina, 0,1 mM nitroblue tetrazolium e 0,3\% TEMED. Ao final de $30 \mathrm{~min}$, a mistura de reação foi removida, os géis enxaguados com água destilada-deionizada e colocados sob iluminação por alguns minutos até o desenvolvimento de bandas brancas sob fundo roxo. SOD bovina (Sigma) foi sempre corrida no gel como padrão interno positivo para atividade de SOD.

Atividade da Ascorbato peroxidase - APX (EC 1.11.1.11) Foi utilizada a metodologia de Nakano \& Asada (1981). A mistura da reação

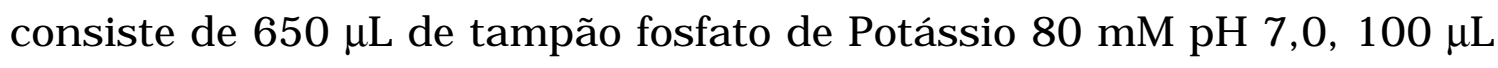
Ascorbato ( $5 \mathrm{mMO}, 100 \mu \mathrm{L}$ EDTA ( $1 \mathrm{mM})$ e $100 \mu \mathrm{L}$ peróxido de hidrogênio $(1 \mathrm{mM})$. A reação foi iniciada com a adição de $50 \mu \mathrm{L}$ do extrato vegetal. A atividade foi determinada seguindo-se a decomposição de peróxido de hidrogênio por 1 min. Por alterações na absorbância a 290 ๆm.

$\underline{\text { Atividade da glutationa redutase }}$ - GR (EC 1.6.4.2.) Foi determinada espectrofotometricamente a $30^{\circ} \mathrm{C}$ em uma mistura de reação consistindo de $3 \mathrm{~mL}$ tampão fosfato de potássio (100 mM) pH 7,5 contendo $1 \mathrm{mM}$ 5,5'-dithio-bis (2-nitrobenzoic acid), $1 \mathrm{mM}$ glutationa oxidada e 0,1 mM NADPH. A reação foi iniciada pela adição de 25-50 $\mu \mathrm{L}$ 
de extrato. GR foi estimada pela redução de glutationa oxidada que foi acompanhada por monitoramento na alteração da absorbância a 412 $\eta \mathrm{m}$.

Determinação de proteína - O método de Bradford foi utilizado para as determinações da concentração de proteínas totais, utilizandose o BSA como padrão.

As atividades específicas foram calculadas a partir da quantidade de proteína total:

Atividade específica de catalase:

[atividade de CAT] $=\frac{[\text { Leitura }(\mathrm{Abs}) / 39400]}{[\text { Teor de prot } / 40]} \times 10^{6}=(\mu \mathrm{mol} / \mathrm{min} / \mathrm{mg} \mathrm{prot})$

Atividade específica de ascorbato peroxidase:

$[$ atividade de APX $]=\frac{[\text { Leitura }(\text { Abs }) \times \text { coef.ext }] \times 60}{[\text { Teor de prot }]}=(\mu \mathrm{mol} / \mathrm{min} / \mathrm{mg}$ prot $)$

Atividade específica de glutationa redutase: [atividade de GR]= [(Leitura (Abs)+0,0134)/1,938] [Teor de prot/40] 
6. Porcentagem de suco

Cada repetição foi pesada e extraído o suco dos frutos. A porcentagem de suco foi calculada através da fórmula: $\%$ de suco = (MS/MF) x 100, onde MS = massa do suco (g) e MF = massa do fruto.

7. Teor de ácido ascórbico

Uma alíquota de $10 \mathrm{~mL}$ se suco foi colocada em erlenmeyer contendo 50mL de solução de ácido oxálico. A titulação foi efetuada com DCFI até atingir a coloração rosada persistente por 15 segundo. Os resultados foram expressos em $\mathrm{mg}$ de ácido ascórbico por 100mL de suco.

8. Coloração da casca

Através do equipamento Minolta Chroma Meter CR-300 foram determinados os valores de ângulo de cor (ho) e chroma $\left(\mathrm{C}^{*}\right)$;

9. Teor de sólidos solúveis totais (SST)

Foi determinado em refratômetro digital, com correção automática de temperatura para $20^{\circ} \mathrm{C}$. Os resultados foram expressos em ${ }^{\circ}$ Brix.

10. Acidez titulável (AT)

Para a determinação da acidez titulável, $10 \mathrm{~mL}$ do suco foram colocados em 90mL de água destilada. Foi efetuada titulação potenciométrica com $\mathrm{NaOH} 1 \mathrm{~N}$ até $\mathrm{pH}$ 8,10. Os resultados foram expressos em \% ácido cítrico.

\section{1. "Ratio"}

Foi calculado pela divisão do teor de SST pela ATT. 
12. Índice tecnológico (I.T.)

Foi calculado através da fórmula: I.T. $=($ SST $x \%$ de suco $) / 100$.

\section{Delineamento experimental e Análise estatística}

O delineamento experimental foi inteiramente ao acaso. Foram utilizadas quatro repetições compostas de 10 frutos. Os resultados coletados foram submetidos à análise de variância (teste F) e as médias comparadas por Tukey (5\%), utilizando-se do pacote SANEST.

As análises fisiológicas foram avaliadas observando as curvas de respiração e produção de etileno, tais como nas análises das atividades enzimáticas. Os dados foram submetidos à análise de variância e as médias foram comparadas pelo teste de diferença mínima significativa em teste de comparações múltiplas, em que as diferenças entre dois tratamentos maior que a soma de dois desvios padrões foram consideradas significativas ao nível de 5\% de probabilidade (Shamaila et al., 1992).

\subsection{Resultados e Discussão}

As análises foram feitas até 45 dias de armazenamento a $1^{\circ} \mathrm{C}$, com comercialização simulada de 4 dias a $25^{\circ} \mathrm{C}$, pois a partir deste período os frutos não estavam em condições comercializáveis, ou seja, correspondeu a máxima vida de prateleira após a refrigeração .

\section{Injúrias pelo frio}

Um dos maiores problemas que impedem um maior período de conservação e comercialização de lima ácida 'Tahiti' é a danificação da 
casca verde, seja por perda da coloração ou por danos provocados pelo frio que ocasionam manchas marrons na superfície dos frutos. Neste sentido têm-se buscado entender o mecanismo de defesa do fruto e procurar tratamentos adicionais à refrigeração que evitem a perda da integridade da casca verde do fruto.

As injúrias pelo frio surgiram a partir de 15 dias de armazenamento (Figura 3). Após 45 dias 100\% dos frutos estavam afetados por injúrias pelo frio, exceto os frutos submetidos ao aquecimento intermitente (Figura 4, 5, 6, 7, 8 e 9).

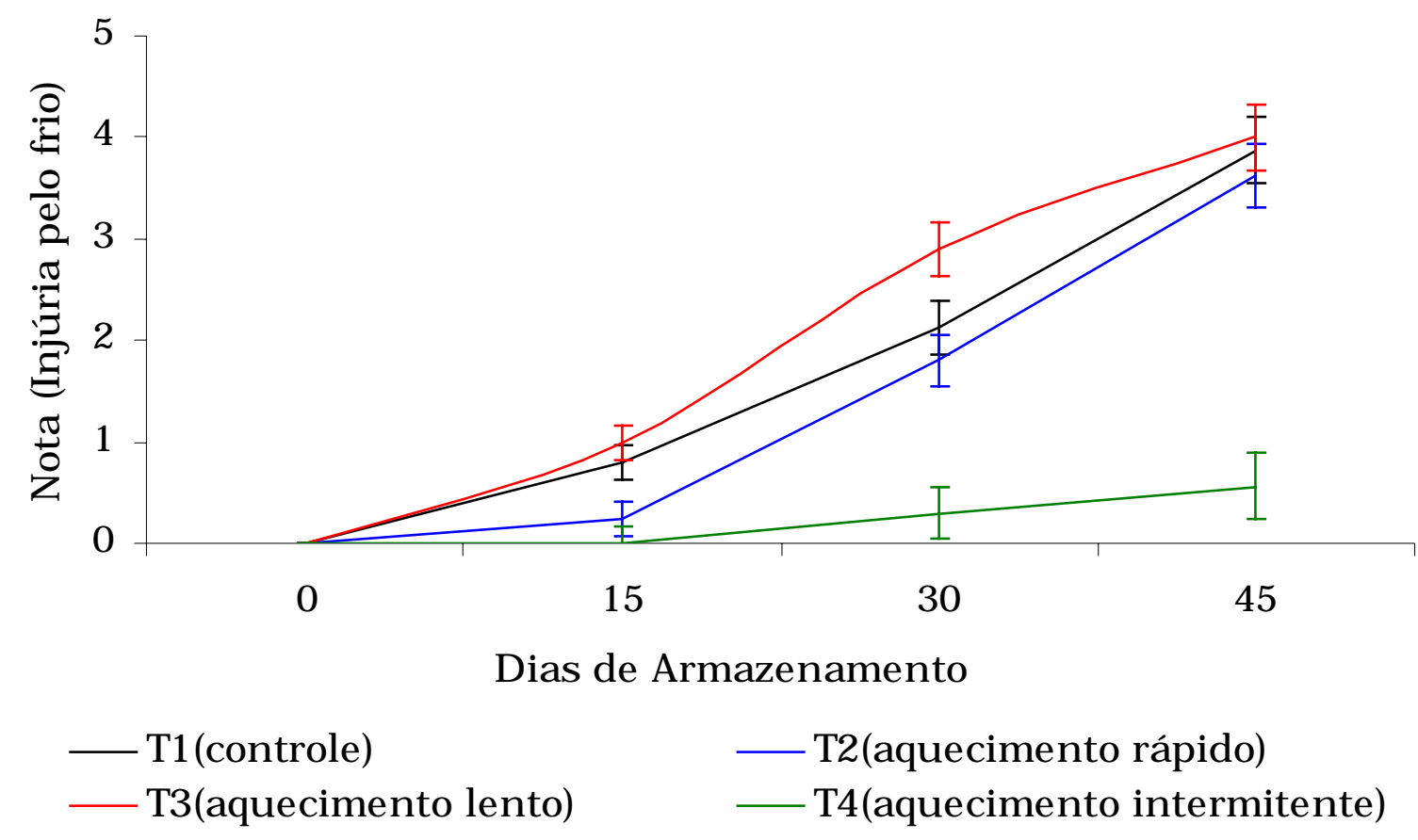

Figura 3 - Efeito dos diferentes tratamentos sobre as injúrias pelo frio em lima ácida 'Tahiti' armazenada a $1^{\circ} \mathrm{C}$. Notas: $0=$ sem depressões superficiais $(0 \%$ da superfície afetada), $1=$ pouco ( 1 a $5 \%$ da superfície afetada), 2 = médio (5-25\%) e 3 $=$ severo $(25-50 \%)$ e $4=$ muito severo $(>50 \%$ da superfície afetada). As barras verticais representam o desvio padrão da média 
$\mathrm{O}$ aquecimento rápido, onde os frutos foram submetidos a $53^{\circ} \mathrm{C}$ durante 3 minutos antes do armazenamento, e o aquecimento intermitente $\left(6\right.$ dias a $1^{\circ} \mathrm{C}$ e 1 dia a $25^{\circ} \mathrm{C}$ ), proporcionaram menor percentual de frutos afetados por depressões superficiais, sintoma característico de injúrias pelo frio em citros, até 30 dias de armazenamento.

Segundo Fallik (2004), o aquecimento rápido em água quente inibe o amadurecimento, reduz a incidência de podridões e as injúrias pelo frio em muitas frutas. Em frutas cítricas foi verificado que o condicionamento térmico também reduziu os danos causados pelas baixas temperaturas, diminuindo a incidência de podridões (BenYehoshua et al., 1987; Del Rio et al., 1992; Gonzalez -Aguilar et al., 1997 e 1998; Schirra \& Mulas, 1993; Rodov et al., 1995 e 2000; Porat et al., 1999; Schirra et al. 2005).

$\mathrm{O}$ aquecimento intermitente, de uma maneira geral, proporcionou os menores percentuais de injúrias pelo frio, onde os sintomas não alcançaram o valor de classificação médio, tendo ficado com nota inferior a 1,0 até 45 dias de armazenamento refrigerado. A interrupção do armazenamento pode induzir a alta atividade metabólica e permitir que o tecido metabolize o excesso de compostos tóxicos acumulados durante o armazenamento refrigerado (Wang, 1994). De fato, a área afetada por depressões superficiais variou de 0 a $5 \%$ da superfície da casca. Semelhantes resultados foram observados em lima ácida 'Tahiti' por Kluge et al. (2003) e por Schirra \& Cohen (1999) em laranjas 'Olinda'. O aquecimento rápido aumentou a tolerância dos frutos ao dano de frio, como também verificado por Lurie (1998) e Paull \& Jung Chen (2000), mas foi somente até 15 dias de armazenamento refrigerado. 
Observou-se que o tratamento com aquecimento lento $\left(37^{\circ} \mathrm{C}\right.$ por 2 dias) não aumentou a resistência dos frutos a baixa temperatura, apresentando alta incidência de dano pelo frio, não diferindo significativamente dos frutos do controle, em oposição ao resultado obtido por Plaza et al. (2003) que, ao submeterem frutos cítricos a 32$38^{\circ} \mathrm{C}$ e $94-98 \%$ por $2-3$ dias, verificaram eficiência deste tratamento no controle de injúrias pelo frio.

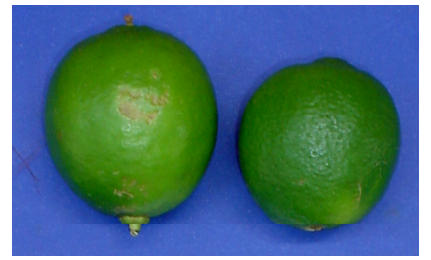

T1

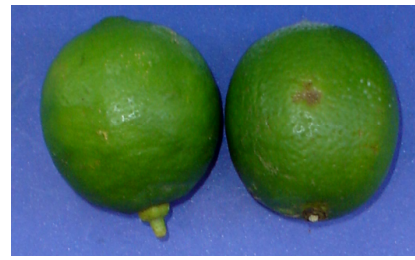

T2

Figura 4 - Frutos do controle (T1) à esquerda; Frutos submetidos ao aquecimento rápido (T2) à direita, aos 15 dias de armazenamento refrigerado mais 3 dias de comercialização simulada a $25^{\circ} \mathrm{C}$

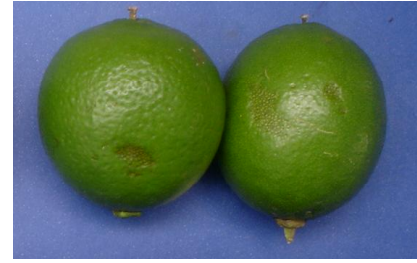

T3

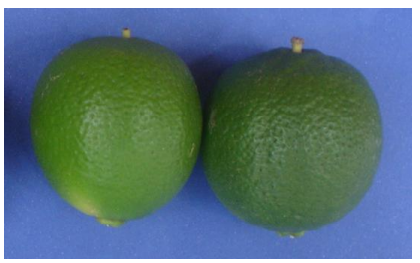

T4

Figura 5 - Frutos submetidos ao aquecimento lento (T3) à esquerda; Frutos submetidos ao aquecimento intermitente (T4) à direita, aos 15 dias de armazenamento refrigerado mais 3 dias de comercialização simulada a $25^{\circ} \mathrm{C}$ 


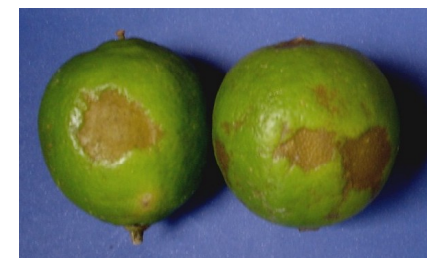

T1

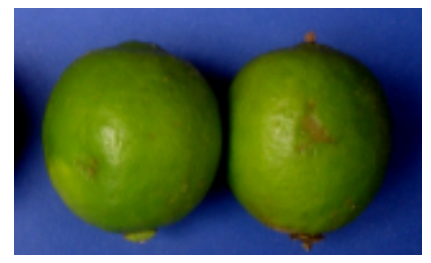

T2

Figura 6 - Frutos do controle (T1) à esquerda; Frutos submetidos ao aquecimento rápido (T2) à direita, aos 30 dias de armazenamento refrigerado mais 3 dias de comercialização simulada a $25^{\circ} \mathrm{C}$

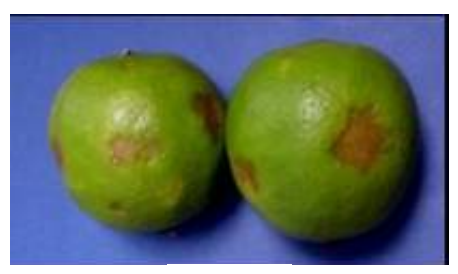

T3

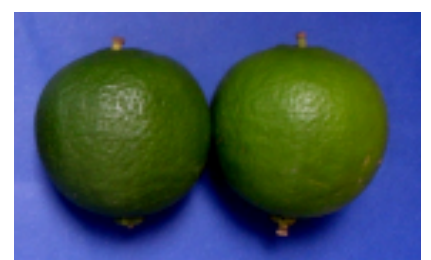

T4

Figura 7 - Frutos submetidos ao aquecimento lento (T3) à esquerda; Frutos submetidos ao aquecimento intermitente (T4) à direita, aos 30 dias de armazenamento refrigerado mais 3 dias de comercialização simulada a $25^{\circ} \mathrm{C}$

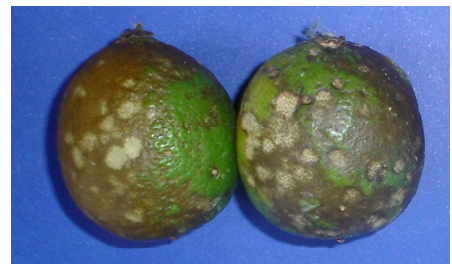

T1

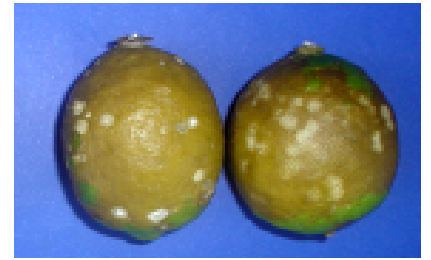

T2

Figura 8 - Frutos do controle (T1) à esquerda; Frutos submetidos ao aquecimento rápido (T2) à direita, aos 45 dias de armazenamento refrigerado mais 3 dias de comercialização simulada a $25^{\circ} \mathrm{C}$ 


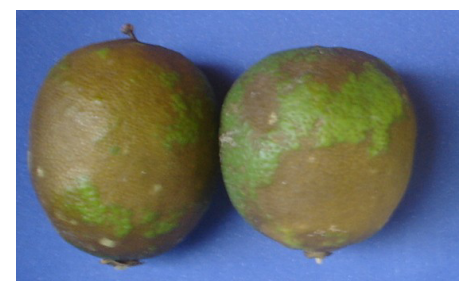

T3

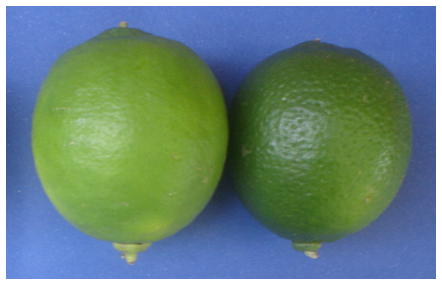

T4

Figura 9 - Frutos submetidos ao aquecimento lento (T3) à esquerda; Frutos submetidos ao aquecimento intermitente (T4) à direita, aos 45 dias de armazenamento refrigerado mais 3 dias de comercialização simulada a $25^{\circ} \mathrm{C}$

\section{Produção de etileno}

O etileno foi detectado até 45 dias de armazenamento refrigerado a $1^{\circ} \mathrm{C}$ (Figura 10), com comercialização simulada de 3 dias a $25^{\circ} \mathrm{C}$, pois a partir deste período os frutos não estavam em condições comercializáveis, somente o tratamento de aquecimento intermitente estava em boas condições, porém o experimento foi finalizado em virtude do delineamento experimental.

Nos frutos submetidos ao aquecimento intermitente foram observadas as menores produções de etileno ao longo do armazenamento. De fato, este tratamento térmico mantém a qualidade dos frutos, não apresentando altos índices de injúria pelo frio, semelhante ao resultado em laranja 'Olinda' de Schirra \& Cohen (1999), os quais verificaram que os frutos submetidos ao aquecimento intermitente tiveram pequenas mudanças na relação de ácido graxo saturado e insaturado mantendo a integridade das membranas e assim não levando ao aparecimento de manchas, características do dano de frio. 
Após 30 dias de armazenamento à baixa temperatura, aumentou a produção de etileno dos outros tratamentos e dos frutos do controle, conforme verificado em maçã e tomate por Lederman et al. (1997) e Autio \& Bramlage (1986), respectivamente, e em outros cultivares de citros por McCollum \& McDonald (1991), que demonstraram que os frutos que tiveram danos pelo frio aumentaram a produção de etileno.

Segundo Jobling et al. (1991) e Larrigaudiere \& Vendrell (1993), a capacidade de converter ACC em etileno é induzido mais rapidamente à baixa temperatura $\left(0-5{ }^{\circ} \mathrm{C}\right)$. Outro fator da alta produção de etileno, é que no processo de transformação da metionina em SAM ocorre o consumo de ATP (Abeles et al., 1992). Este ATP é decorrente da cadeia respiratória. Os frutos do controle apresentaram uma alta taxa respiratória, assim produzindo ATP, necessário para a produção de SAM, assim elevando a produção de etileno. $O$ aquecimento intermitente, que apresentou baixa produção de etileno, apresentou também baixa taxa respiratória.

Foram observadas que os frutos submetidos aos condicionamentos térmicos tiveram menor produção de etileno, com diferença significativa, em relação aos frutos do controle aos 45 dias de armazenamento. Segundo Yu et al. (1980) temperaturas acima de $30^{\circ} \mathrm{C}$ inibem a conversão de ACC em etileno.

A correlação entre produção de etileno com desenvolvimento de sintomas de injúrias pelo frio parece não existir, uma vez que os frutos mais afetados tiveram alta produção de etileno. Lederman, et al. (1997) e Autio \& Bramlage (1986) relataram que uma das alterações marcantes em frutos que sofrem injúrias pelo frio é o aumento na produção de etileno, mas esta parece ser uma causa secundária do aparecimento dos sintomas. 


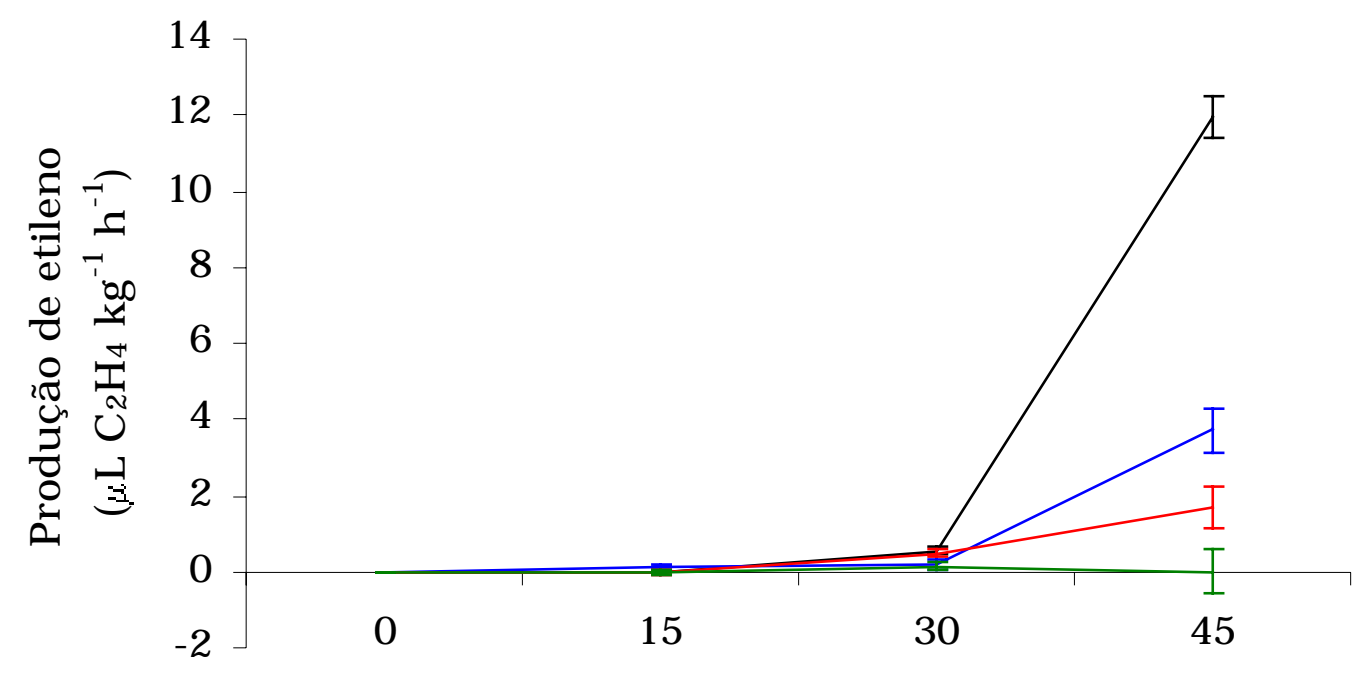

Dias de armazenamento

— T1(controle)

— T3(aquecimento lento)
— T2(aquecimento rápido)

— T4(aquecimento intermitente)

Figura 10 - Efeito dos diferentes tratamentos sobre a produção de etileno em lima ácida 'Tahiti' armazenada a $1^{\circ} \mathrm{C}$. As barras verticais representam o desvio padrão da média

\section{Taxa respiratória}

Os frutos submetidos ao aquecimento intermitente mantiveram baixa a taxa respiratória, diferindo dos outros tratamentos aos 45 dias de armazenamento (Figura 11). Esse fato ocorreu devido à reduzida incidência de injúria pelo frio desses frutos. De fato, o estresse pelo frio aumenta a taxa respiratória como um mecanismo de defesa da planta para recuperar o tecido injuriado (Fallik, 2004).

$\mathrm{O}$ aquecimento lento aumentou a taxa respiratória dos frutos, o que foi verificado por Holland et al. (2002) em tangerina 'Fortune' aquecida a $37^{\circ} \mathrm{C}$ por 3 dias antes da refrigeração. 


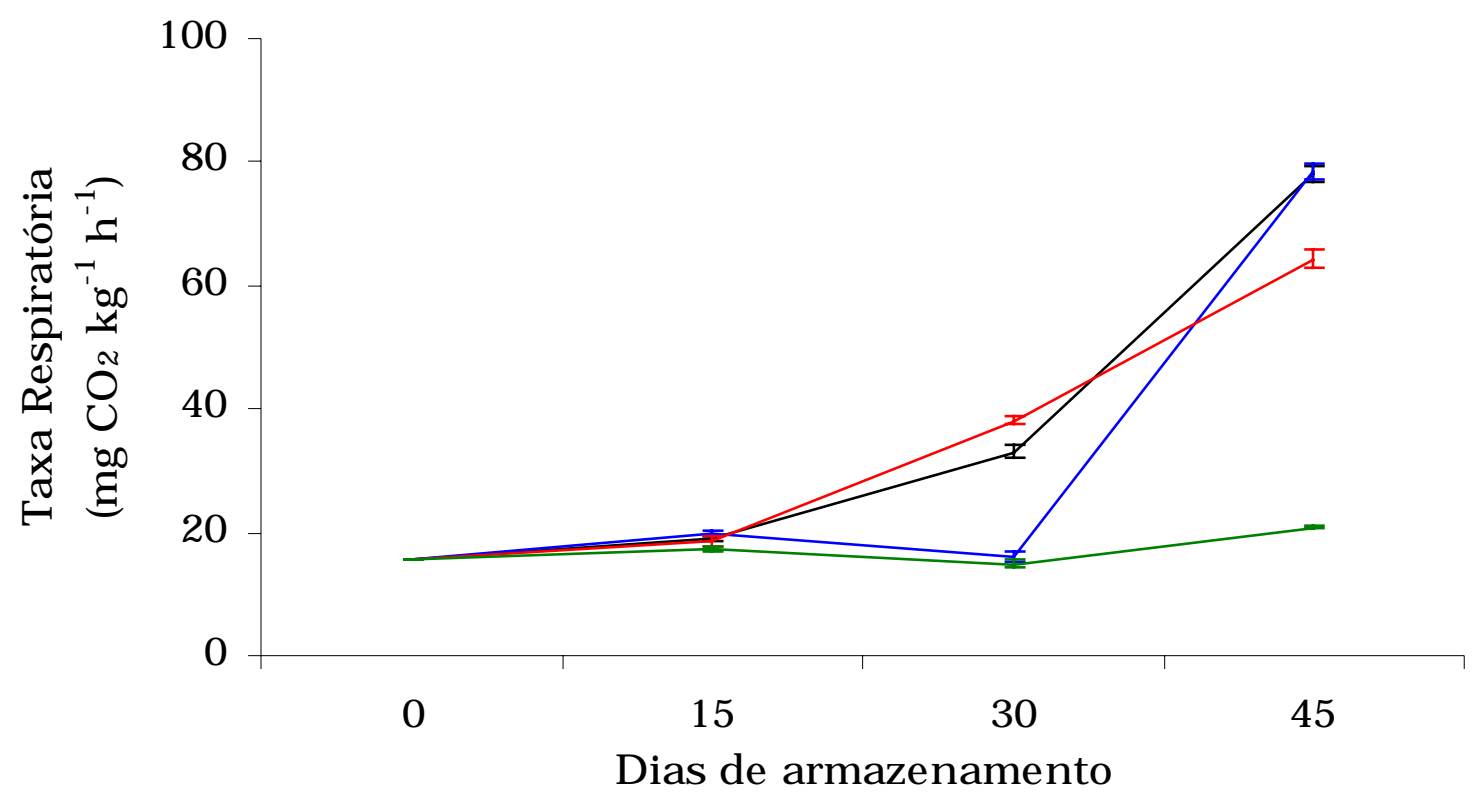

- T1(controle)

— T3(aquecimento lento)
— T2(aquecimento rápido)

— T4(aquecimento intermitente)

Figura 11 - Efeito dos diferentes tratamentos sobre a taxa respiratória em lima ácida 'Tahiti' armazenada a $1^{\circ} \mathrm{C}$. As barras verticais representam o desvio padrão da média

\section{Porcentagem de suco}

De maneira geral, observa-se que ao longo do armazenamento a porcentagem de suco diminuiu, porém nos frutos que sofreram o aquecimento intermitente observou estabilidade (Tabela 1). Nos outros tratamentos térmicos (aquecimento rápido e lento) houve porcentagem de suco igual aos frutos do controle.

Aos 30 dias de armazenamento observa-se um aumento na porcentagem de suco nos frutos submetidos aos tratamentos térmicos. Esse fato pode ter sido devido à perda de água por transpiração, que 
aumenta a relação de suco sobre a massa total dos frutos, pois a transpiração fica restrita apenas no flavedo, não interferindo a quantidade de suco (Jomori et al., 2003).

Tabela 1. Porcentagem de suco de lima ácida 'Tahiti' armazenada a $1^{\circ} \mathrm{C}$ em função dos tratamentos ${ }^{1}$

Tempo de armazenamento

Tratamentos $^{2} \quad 0$ dias 15 dias 30 dias 45 dias Médias

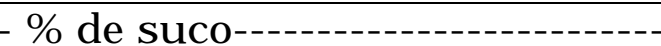

$\mathrm{T} 1$

$\mathrm{T} 2$

T3

T4

47,43 a A 44,14 a A 42,66 b A 36,01 b B 42,56 b

47,43 a A 43,75 a A 45,48 ab A 36,83 b B 43,37 b

47,43 a A 42,08 a $\mathrm{AB} \quad 47,04$ ab A 39,30 b B 43,96 b

Médias 47,43 a $\mathrm{A} \quad 45,44$ a $\mathrm{A} \quad 48,93$ a A 48,38 a A 45,54 a

${ }^{1}$ Médias seguidas de mesma letra minúscula na coluna e maiúscula na linha não diferem entre si pelo teste de Tukey (5\%). C.V (\%) = 6,62

${ }^{2} \mathrm{~T} 1=$ controle; $\mathrm{T} 2=$ aquecimento rápido $\left(53^{\circ} \mathrm{C} / 3 \mathrm{~min}\right) ; \mathrm{T} 3=$ aquecimento lento $\left(37^{\circ} \mathrm{C} / 2\right.$ dias); $\mathrm{T} 4=$ aquecimento intermitente $\left(6\right.$ dias a $1^{\circ} \mathrm{C}+1$ dia a $\left.25^{\circ} \mathrm{C}\right)$.

\section{Teor de Ácido Ascórbico}

O teor de ácido ascórbico é um importante atributo de qualidade dos frutos cítricos em geral. De modo geral, observa-se uma queda do teor de ácido ascórbico de até $20 \%$ durante o armazenamento (Tabela 2). Esta redução pode estar relacionada com a própria senescência do fruto, onde o ácido ascórbico é consumido em reações oxidativas. O ácido ascórbico é o maior composto antioxidante encontrado em no suco dos citros (Gardner et al., 2000).

Schirra et al. (2005) observaram que frutos de laranjas sanguíneas submetidas ao aquecimento com água quente e com ar quente apresentaram redução no teor de ácido ascórbico, concordando 
com o observado no presente trabalho para os aquecimentos lento e rápido. $\mathrm{O}$ aquecimento intermitente foi o tratamento que proporcionou menores reduções no teor de ácido ascórbico, provavelmente devido às menores reações antioxidativas resultante da menor manifestação de injúrias pelo frio. Assim, como não ocorreu o dano de frio nos frutos deste tratamento, menor quantidade de ácido ascórbico foi utilizada em reações antioxidativas.

Tabela 2. Teor de ácido ascórbico de lima ácida 'Tahiti' armazenada a $1^{\circ} \mathrm{C}$ em função dos tratamentos ${ }^{1}$

\begin{tabular}{|c|c|c|c|c|c|}
\hline \multirow[b]{2}{*}{ Tratamentos $^{2}$} & \multicolumn{5}{|c|}{ Tempo de armazenamento } \\
\hline & 0 dias & 15 dias & 30 dias & 45 dias & Médias \\
\hline \multicolumn{6}{|c|}{----- Ácido Ascórbico (mg/100 ml suco)----- } \\
\hline $\mathrm{T} 1$ & 37,34 a A & 33,79 a $A$ & 33,77 a $A$ & 29,12 a $A$ & $33,60 \mathrm{ab}$ \\
\hline $\mathrm{T} 2$ & 37,34 a A & 31,14 a $A$ & 28,87 a $A$ & 29,94 a A & $31,67 \mathrm{~b}$ \\
\hline T3 & 37,34 a A & 31,27 a $\mathrm{A}$ & 30,39 a $A$ & 30,58 a $A$ & $32,49 \mathrm{ab}$ \\
\hline $\mathrm{T} 4$ & 37,34 a A & 40,62 a $A$ & 37,30 a $A$ & 33,26 a $A$ & $37,23 \mathrm{a}$ \\
\hline Médias & $37,34 \mathrm{~A}$ & $34,20 \mathrm{AB}$ & $32,58 \mathrm{AB}$ & $30,47 \mathrm{~B}$ & \\
\hline
\end{tabular}

\section{Coloração da casca (Ângulo de cor - ${ }^{\circ}$ h)}

Ao longo do armazenamento observou-se o decréscimo do ângulo de cor, evidenciando a perda da cor verde da casca. Somente o tratamento de aquecimento intermitente preservou a coloração verde da casca até 45 dias de armazenamento (Tabela 3). De fato, a área afetada por depressões superficiais variou de 0 a $5 \%$ da superfície da casca dos frutos que sofreram o aquecimento intermitente, onde os sintomas não 
alcançaram o valor de classificação médio, tendo ficado com nota inferior a 1,0 até o final do armazenamento.

Tabela 3. Coloração da casca (ângulo de cor) de lima ácida 'Tahiti' armazenada a $1^{\circ} \mathrm{C}$ em função dos tratamentos ${ }^{1}$

\section{Tempo de armazenamento}

Tratamentos $^{2} \quad 0$ dias 15 dias 30 dias 45 dias Médias

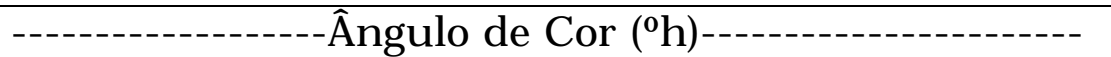

$\mathrm{T} 1$

T2

T3

$\mathrm{T} 4$

Médias 122,3 a A 118,3 a AB 113,8 b B $\quad 111,9$ b B $\quad 116,6$ b 122,3 a A 121,85 a A 116,4 ab B 109,7 bc C 117,6 ab 122,3 a A 117,5 a B 115,0 ab B 102,5 c C 114.3 c

${ }^{1}$ Médias seguidas de mesma letra minúscula na coluna e maiúscula na linha não diferem entre si pelo teste de Tukey $(5 \%)$. C.V $(\%)=2,18$

${ }^{2} \mathrm{~T} 1$ = controle; $\mathrm{T} 2=$ aquecimento rápido $\left(53^{\circ} \mathrm{C} / 3 \mathrm{~min}\right) ; \mathrm{T} 3=$ aquecimento lento $\left(37^{\circ} \mathrm{C} / 2\right.$ dias); $\mathrm{T} 4=$ aquecimento intermitente $\left(6\right.$ dias a $1^{\circ} \mathrm{C}+1$ dia a $\left.25^{\circ} \mathrm{C}\right)$.

\section{Teor de sólidos solúveis totais (SST)}

O teor SST teve pouca variação durante o experimento, tendo variado de 7,82 a $8,82^{\circ}$, (Tabela 4 ).

De modo geral, observou-se que ao longo do armazenamento houve um decréscimo do teor de sólidos solúveis. Os sólidos solúveis totais são compostos solúveis em água e importantes na determinação da qualidade da fruta. O teor de SST nos dá o indicativo da quantidade de açúcares existentes da fruta, além de compostos como ácidos, vitaminas, aminoácidos e algumas pectinas (Kluge et al., 2002). Esses compostos são substratos da respiração, que é o principal processo metabólico dos frutos, após a colheita, que consiste na conversão desses compostos em energia química para manterem sua atividade 
metabólica, uma vez que não existe mais relação fonte-dreno com a planta.

Embora a lima ácida 'Tahiti' seja um fruto não climatérico e possua baixa taxa respiratória, é provável que parte dos sólidos solúveis tenha sido consumida na atividade respiratória.

Tabela 4. Teor de sólidos solúveis de lima ácida 'Tahiti' armazenada a $1^{\circ} \mathrm{C}$ em função dos tratamentos ${ }^{1}$

\begin{tabular}{lccccc}
\hline & \multicolumn{5}{c}{ Tempo de armazenamento } \\
Tratamentos & 0 dias & 15 dias & 30 dias & 45 dias & Médias \\
\hline \multirow{2}{*}{ T1 } & ----------- & Teor de sólidos solúveis $\left({ }^{\circ}\right.$ Brix)------------- \\
T2 & $8,32 \mathrm{a} \mathrm{A}$ & $8,15 \mathrm{a} \mathrm{A}$ & $8,40 \mathrm{ab} \mathrm{A}$ & $7,95 \mathrm{a} \mathrm{A}$ & $8,20 \mathrm{~b}$ \\
$\mathrm{~T} 3$ & $8,32 \mathrm{a} \mathrm{AB}$ & $8,54 \mathrm{a} \mathrm{A}$ & $8,12 \mathrm{~b} \mathrm{AB}$ & $7,92 \mathrm{a} \mathrm{B}$ & $8,23 \mathrm{ab}$ \\
$\mathrm{T} 4$ & $8,32 \mathrm{aA}$ & $8,20 \mathrm{a} \mathrm{A}$ & $8,10 \mathrm{~b} \mathrm{~A}$ & $7,82 \mathrm{a} \mathrm{A}$ & $8,11 \mathrm{~b}$ \\
Médias & $8,32 \mathrm{a} \mathrm{AB}$ & $8,52 \mathrm{a} \mathrm{AB}$ & $8,82 \mathrm{a} \mathrm{A}$ & $8,22 \mathrm{a} \mathrm{B}$ & $8,47 \mathrm{a}$ \\
& $8,32 \mathrm{~A}$ & $8,35 \mathrm{~A}$ & $8,36 \mathrm{~A}$ & $7,46 \mathrm{~B}$ & \\
\hline
\end{tabular}

${ }^{1}$ Médias seguidas de mesma letra minúscula na coluna e maiúscula na linha não diferem entre si pelo teste de Tukey (5\%). C.V (\%) $=3,28$

$2 \mathrm{~T} 1$ = controle; $\mathrm{T} 2$ = aquecimento rápido $\left(53^{\circ} \mathrm{C} / 3 \mathrm{~min}\right) ; \mathrm{T} 3=$ aquecimento lento $\left(37^{\circ} \mathrm{C} / 2\right.$ dias); $\mathrm{T} 4=$ aquecimento intermitente $\left(6\right.$ dias a $1^{\circ} \mathrm{C}+1$ dia a $\left.25^{\circ} \mathrm{C}\right)$.

\section{Acidez titulável (AT)}

De modo geral, houve decréscimo do teor de acidez titulável ao longo do armazenamento (Tabela 5). Essa diminuição é um processo que pode ocorrer, considerando que os ácidos podem também servir de substratos para a respiração (Awad, 1993). Segundo Fernanda (1996), alta taxa respiratória aumenta o consumo de ácido cítrico, substrato metabólico da respiração.

Os frutos submetidos ao condicionamento térmico (rápido e lento) obtiveram menor teor acidez, resultado semelhante observado em maçãs 
por Liu (1978). Assim, o aquecimento dos frutos provavelmente aumentou a taxa respiratória, o que possivelmente incrementou o consumo de ácidos orgânicos no processo respiratório. Plaza et al. (2004) verificou que frutos de tangerina 'Clementina' submetidos ao condicionamento térmico a $40^{\circ} \mathrm{C}$ por 24 horas tiveram menores teores de ácido cítrico ao final do período de armazenamento.

Lederman et al. (1997) e Autio \& Bramlage (1986) comentam que um dos danos provocados pelo frio em frutas é o aumento desordenado na produção de etileno e respiração. Isso pode ter provocado, no presente trabalho, a utilização de quantidade de ácidos no processo respiratório dos frutos submetidos aos tratamentos que apresentaram injúria pelo frio.

Tabela 5. Acidez titulável de lima ácida 'Tahiti' armazenada a $1^{\circ} \mathrm{C}$ em função dos tratamentos ${ }^{1}$

\begin{tabular}{lccccc}
\hline & \multicolumn{5}{c}{ Tempo de armazenamento } \\
Tratamentos $^{2}$ & 0 dias & 15 dias & 30 dias & 45 dias & Médias \\
\hline \multirow{2}{*}{ T1 } & ---------- & Acidez Titulável (\% ácido cítrico)------------ \\
T2 & 6,00 a AB & 6,20 a A & 5,61 a BC & $5,27 \mathrm{~b} \mathrm{C}$ & $5,77 \mathrm{ab}$ \\
T3 & 6,00 a A & $5,67 \mathrm{~b} \mathrm{~A}$ & 5,93 a A & $4,84 \mathrm{~b} \mathrm{~B}$ & $5,61 \mathrm{~b}$ \\
T4 & $6,00 \mathrm{a} \mathrm{A}$ & $5,65 \mathrm{~b} \mathrm{~A}$ & $5,63 \mathrm{a} \mathrm{A}$ & $5,17 \mathrm{~b} \mathrm{~B}$ & $5,61 \mathrm{~b}$ \\
Médias & $6,00 \mathrm{a} \mathrm{A}$ & $5,92 \mathrm{ab} \mathrm{A}$ & $5,66 \mathrm{a} \mathrm{A}$ & $6,07 \mathrm{a} \mathrm{A}$ & $5,91 \mathrm{a}$ \\
& $6,00 \mathrm{~A}$ & $5,86 \mathrm{AB}$ & $5,81 \mathrm{~B}$ & $5,33 \mathrm{C}$ & \\
\hline
\end{tabular}

${ }^{1}$ Médias seguidas de mesma letra minúscula na coluna e maiúscula na linha não diferem entre si pelo teste de Tukey (5\%). C.V (\%) $=4,27$

$2 \mathrm{~T} 1$ = controle; $\mathrm{T} 2$ = aquecimento rápido $\left(53^{\circ} \mathrm{C} / 3 \mathrm{~min}\right) ; \mathrm{T} 3=$ aquecimento lento $\left(37^{\circ} \mathrm{C} / 2\right.$ dias $) ; \mathrm{T} 4=$ aquecimento intermitente $\left(6\right.$ dias a $1^{\circ} \mathrm{C}+1$ dia a $\left.25^{\circ} \mathrm{C}\right)$. 
"Ratio"

O "ratio" apresentou pouca variação durante o experimento, tendo os valores oscilados entre 1,39 e 1,64 (Tabela 6). Esse valor é próximo de 1,0 devido que a lima ácida 'Tahiti' tem baixo teor de açúcar e alta acidez.

Ao longo do armazenamento houve um pequeno aumento do "ratio", devido a relação existente entre o teor de sólidos solúveis e a acidez, onde a acidez caiu mais rápido que o teor de sólidos solúveis.

Tabela 6. "Ratio" de lima ácida 'Tahiti' armazenada a $1^{\circ} \mathrm{C}$ em função dos tratamentos ${ }^{1}$

\begin{tabular}{lccccc}
\hline & \multicolumn{5}{c}{ Tempo de armazenamento } \\
Tratamentos $^{2}$ & 0 dias & 15 dias & 30 dias & 45 dias & Médias \\
\hline \multirow{2}{*}{ T1 } & --1,39 a AB & $1,31 \mathrm{~b} \mathrm{~B}$ & $1,50 \mathrm{ab} \mathrm{A}$ & $1,51 \mathrm{ab} \mathrm{A}$ & $1,43 \mathrm{a}$ \\
$\mathrm{T} 2$ & $1,39 \mathrm{a} \mathrm{B}$ & $1,51 \mathrm{a} \mathrm{AB}$ & $1,37 \mathrm{~b} \mathrm{~B}$ & $1,64 \mathrm{a} \mathrm{A}$ & $1,48 \mathrm{a}$ \\
$\mathrm{T} 4$ & $1,39 \mathrm{a} \mathrm{A}$ & $1,45 \mathrm{ab} \mathrm{A}$ & $1,44 \mathrm{ab} \mathrm{A}$ & $1,51 \mathrm{ab} \mathrm{A}$ & $1,45 \mathrm{a}$ \\
$\mathrm{T} 4$ & $1,39 \mathrm{a} \mathrm{B}$ & $1,44 \mathrm{ab} \mathrm{AB}$ & $1,56 \mathrm{a} \mathrm{A}$ & $1,35 \mathrm{~b} \mathrm{~B}$ & $1,44 \mathrm{a}$ \\
Médias & $1,39 \mathrm{~B}$ & $1,43 \mathrm{AB}$ & $1,46 \mathrm{AB}$ & $1,50 \mathrm{a} \mathrm{A}$ & \\
\hline
\end{tabular}

${ }^{1}$ Médias seguidas de mesma letra minúscula na coluna e maiúscula na linha não diferem entre si pelo teste de Tukey (5\%). C.V (\%) $=5,88$

${ }^{2} \mathrm{~T} 1=$ controle; $\mathrm{T} 2=$ aquecimento rápido $\left(53^{\circ} \mathrm{C} / 3 \mathrm{~min}\right) ; \mathrm{T} 3=$ aquecimento lento $\left(37^{\circ} \mathrm{C} / 2\right.$ dias); $\mathrm{T} 4=$ aquecimento intermitente $\left(6\right.$ dias a $1^{\circ} \mathrm{C}+1$ dia a $\left.25^{\circ} \mathrm{C}\right)$.

\section{Índice tecnológico (I.T.)}

Observa-se um maior índice tecnológico dos frutos submetidos ao aquecimento intermitente e, de modo geral, um decréscimo nesse índice ao longo do armazenamento (Tabela 7). O I.T. é a determinação que leva 
em consideração o teor de sólidos solúveis, valores estes que foram maiores nos frutos que sofreram aquecimento intermitente.

Tabela 7. Índice tecnológico de lima ácida 'Tahiti' armazenada a $1^{\circ} \mathrm{C} \mathrm{em}$ função dos tratamentos ${ }^{1}$

\begin{tabular}{lccccc}
\hline \multirow{2}{*}{ Tratamentos $^{2}$} & \multicolumn{5}{c}{ Tempo de armazenamento } \\
& dias & 15 dias & 30 dias & 45 dias & Médias \\
\hline T1 & 3,95 a A & 3,60 a A & $3,58 \mathrm{~b} \mathrm{~A}$ & $2,86 \mathrm{~b} \mathrm{~B}$ & $3,50 \mathrm{~b}$ \\
$\mathrm{~T} 2$ & $3,95 \mathrm{a} A$ & $3,73 \mathrm{a} \mathrm{A}$ & $3,69 \mathrm{~b} \mathrm{~A}$ & $2,71 \mathrm{~b} \mathrm{~B}$ & $3,57 \mathrm{~b}$ \\
$\mathrm{~T} 3$ & $3,95 \mathrm{a} A$ & $3,45 \mathrm{a} \mathrm{BC}$ & $3,81 \mathrm{~b} \mathrm{AB}$ & $3,08 \mathrm{~b} \mathrm{C}$ & $3,57 \mathrm{~b}$ \\
T4 & $3,95 \mathrm{a} A$ & $3,87 \mathrm{a} \mathrm{A}$ & $4,31 \mathrm{a} \mathrm{A}$ & $3,98 \mathrm{a} \mathrm{A}$ & $4,03 \mathrm{a}$ \\
Médias & $3,95 \mathrm{~A}$ & $3,66 \mathrm{~B}$ & $3,85 \mathrm{AB}$ & $3,21 \mathrm{C}$ & \\
\hline
\end{tabular}

${ }^{1}$ Médias seguidas de mesma letra minúscula na coluna e maiúscula na linha não diferem entre si pelo teste de Tukey (5\%). C.V (\%) $=6,66$

$2 \mathrm{~T} 1$ = controle; $\mathrm{T} 2=$ aquecimento rápido $\left(53^{\circ} \mathrm{C} / 3 \mathrm{~min}\right) ; \mathrm{T} 3=$ aquecimento lento $\left(37^{\circ} \mathrm{C} / 2\right.$ dias); $\mathrm{T} 4=$ aquecimento intermitente $\left(6\right.$ dias a $1^{\circ} \mathrm{C}+1$ dia a $\left.25^{\circ} \mathrm{C}\right)$.

\section{Atividade de enzimas antioxidantes}

As atividades das enzimas foram determinadas logo após a retirada dos frutos do armazenamento refrigerado a $1^{\circ} \mathrm{C}$, após 15 e 30 dias. Aos 45 dias de armazenamento os frutos não foram avaliados, pois não estavam em condições comercializáveis, sendo que os danos pelo frio (manchas na casca) ultrapassavam 50\% da área total da casca (nota 4 = muito severa), exceto os frutos do tratamento 4 (aquecimento intermitente), porém não foram determinadas as atividades enzimáticas em virtude do delineamento experimental. Foram avaliadas as atividades de catalase (CAT), superóxido dismutase (SOD), ascorbato peroxidase (APX) e glutationa redutase (GR). 
Observou-se que houve variações das atividades das enzimas antioxidativas e diferença significativa entre os tratamentos. Esse fato era esperado, pois o estresse pelo frio é considerado um estresse oxidativo (Rao et al., 1996), onde há produção de espécies ativas de oxigênio (superóxido e peróxido de hidrogênio) (Wise \& Naylor, 1987). Nas plantas existem um complexo sistema antioxidante que protegem contra os altos níveis das espécies ativas de oxigênio, o qual incluem três classes: lipossolúveis (antioxidantes associados a membrana - $\alpha$ tocopherol, e $\beta$ caroteno), hidrossolúveis (glutationa e ascorbato), e por fim o sistema enzimático (por exemplo, Superóxido Dismutase, Catalase e Peroxidase).

A CAT atua como regulador dos niveis de $\mathrm{H}_{2} \mathrm{O}_{2}$, os quais são decompostos em $\mathrm{H}_{2} \mathrm{O}$ e $\mathrm{O}_{2}$ (Scandalios, 1990), e esse $\mathrm{H}_{2} \mathrm{O}_{2}$ é tóxico a célula, sendo uns dos compostos que leva à morte celular, que no caso do estresse pelo frio causa manchas deprimidas necróticas na casca de lima ácida 'Tahiti'. A atividade da CAT (Figura 12) apresentou variações significativas durante o período de armazenamento e entre os tratamentos, onde pode ser observado que os frutos que foram submetidos ao tratamento de aquecimento intermitente obteve maior atividade da CAT, verificando também que os frutos destes tratamentos não obtiveram elevado índice de injúria pelo frio, podendo, então, associar a atividade da CAT com a resistência dos frutos à baixa temperatura, conforme verificado em outras variedades de citrus (Sala \& Lafuente, 2000; Sala \& Lafuente, 1999; Sala, 1998).

A atividade de CAT nos frutos que foram submetidos ao aquecimento rápido não diferiu significativamente dos frutos do controle. Já os frutos que foram submetidos ao aquecimento lento obteve menor atividade de CAT, podendo ser devido à longa exposição dos frutos a alta temperatura, o que interferiu na atividade da enzima. 


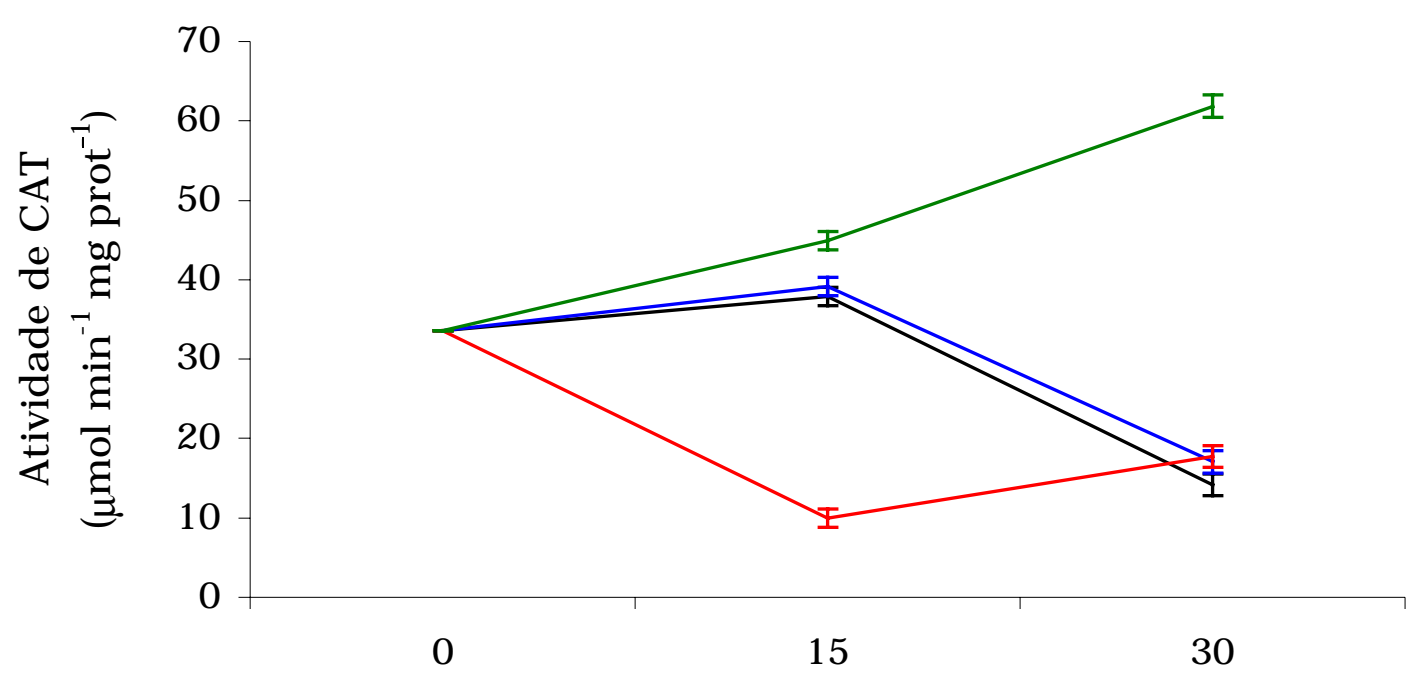

Dias de armazenamento

- T1(controle)

— T3(aquecimento lento)
— T2(aquecimento rápido)

— T4(aquecimento intermitente)

Figura 12 - Atividade específica de catalase (CAT) em lima ácida 'Tahiti' armazenada a $1^{\circ} \mathrm{C}$. As barras verticais representam o desvio padrão da média

Os resultados de PAGE - gel não desnaturante (Figura 13 e 14) demonstraram variação na atividade total das isoformas de SOD, relacionadas aos tratamentos e tempo de armazenamento.

As SODs são enzimas que contém metais ligados a sua estrutura e catalisam a dismutação do radical superóxido em $\mathrm{O}_{2}$ e $\mathrm{H}_{2} \mathrm{O}_{2}$ (Mattson, 1998), regulando assim, os níveis de superóxido e peróxido de hidrogênio que são substratos da reação que origina os radicais de hidroxila, representando por isso, o papel central no mecanismo de defesa antioxidante (Alscher et al., 1998; 2002). 
Em plantas existem três formas desta enzima, as quais são classificadas segundo o íon metálico em seu sítio ativo: formas cobre/zinco (Cu/Zn-SOD), manganês (Mn-SOD) e ferro (Fé-SOD) (Bowler et al., 1994; Chen \& Liu, 1996).

A atividade de SOD, bem como a expressão dos genes que codificam suas isoformas, tem mostrado sofrer alterações sob diversas condições de estresse (Willekens et al., 1995).

Observa-se que todos tratamentos apresentaram a atividade de SOD, e suas isoformas. Os frutos da caracterização e do controle apresentaram as três isoformas, evidenciando alta atividade da enzima e assim mais formação de peróxido de hidrogênio.

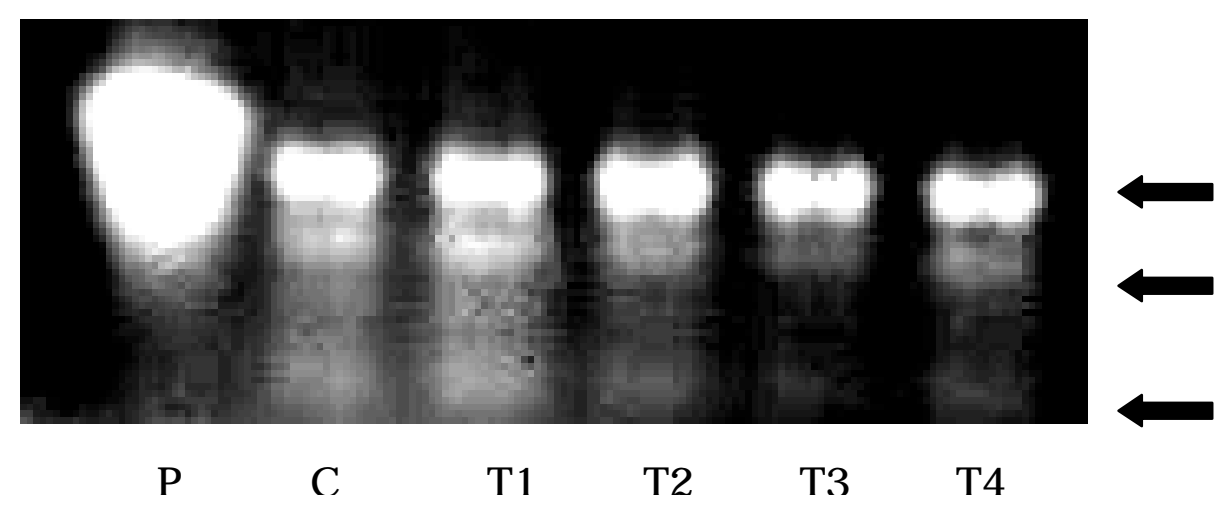

Figura 13 - Atividade de SOD de lima ácida 'Tahiti' armazenada a $1^{\circ} \mathrm{C}$, determinada em PAGE não desnaturante; (P) padrão de SOD de fígado bovino, (C) caracterização, (T1) controle, (T2) aquecimento rápido, (T3) aquecimento lento, (T4) aquecimento intermitente, aos 15 dias de armazenamento refrigerado. As setas representam as isoformas de SOD 


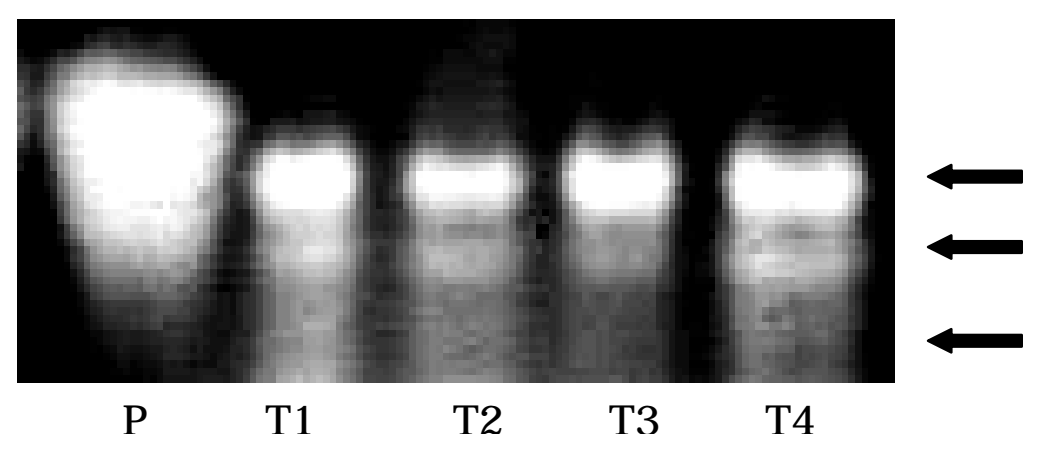

Figura 14 - Atividade de SOD de lima ácida 'Tahiti' armazenada a $1^{\circ} \mathrm{C}$, determinada em PAGE não desnaturante; (P) padrão de SOD de fígado bovino, (T1) controle, (T2) aquecimento rápido, (T3) aquecimento lento, (T4) aquecimento intermitente, aos 30 dias de armazenamento refrigerado. As setas representam as isoformas de SOD

A glutationa representa muitas funções no metabolismo de plantas. Está envolvida na desintoxicação de metais e tem papel na ativação gênica e na proteção de estresse oxidativo, como o causado pelo frio (Noctor \& Foyer, 1998; Schutzendubel et al., 2001). Como antioxidantes, a glutationa, o ascorbato e as enzimas como SOD, CAT e APX controlam as concentrações celulares de superóxido e peróxido de hidrogênio. A reciclagem de ascorbato e glutationa é realizada pela monodehidroascorbato, dehidroascorbato redutase e glutationa redutase (GR) (Schutzendubel et al., 2001). A GR é a enzima chave do ciclo ascorbato-glutationa. Vários papéis metabólicos, regulatórios e antioxidativos da glutationa reduzida, resultam da oxidação a glutationa oxidada. Para a maioria dessas funções a glutationa deve estar na sua forma reduzida, conduzida pela flavoproteína glutationa redutase em uma reação de óxido-redução NADPH-dependente da glutationa oxidada para reduzida (Creissen at al., 1994a). Observa-se que houve a atividade 
da GR, porém não diferiu significativamente entre os tratamentos (Figura 15), ao longo do armazenamento, mas verifica um aumento da atividade aos 15 dias de armazenamento refrigerado, o que é necessário, pois aumenta os níveis de glutationa, bem como a regeneração do ascorbato, dois importantes anioxidantes do sistema celular (Beck et al., 2003).

A glutationa reage quimicamente com os radicais livres, enquanto as enzimas catalisam reações ligando a glutationa reduzida a desintoxicação de $\mathrm{H}_{2} \mathrm{O}_{2}$ no ciclo ascorbato-glutationa. Como foi verificado, é necessário que tenha atividade de GR para manter os níveis celulares de glutationa, tanto reduzida quanto oxidada (Noctor et al., 2002).

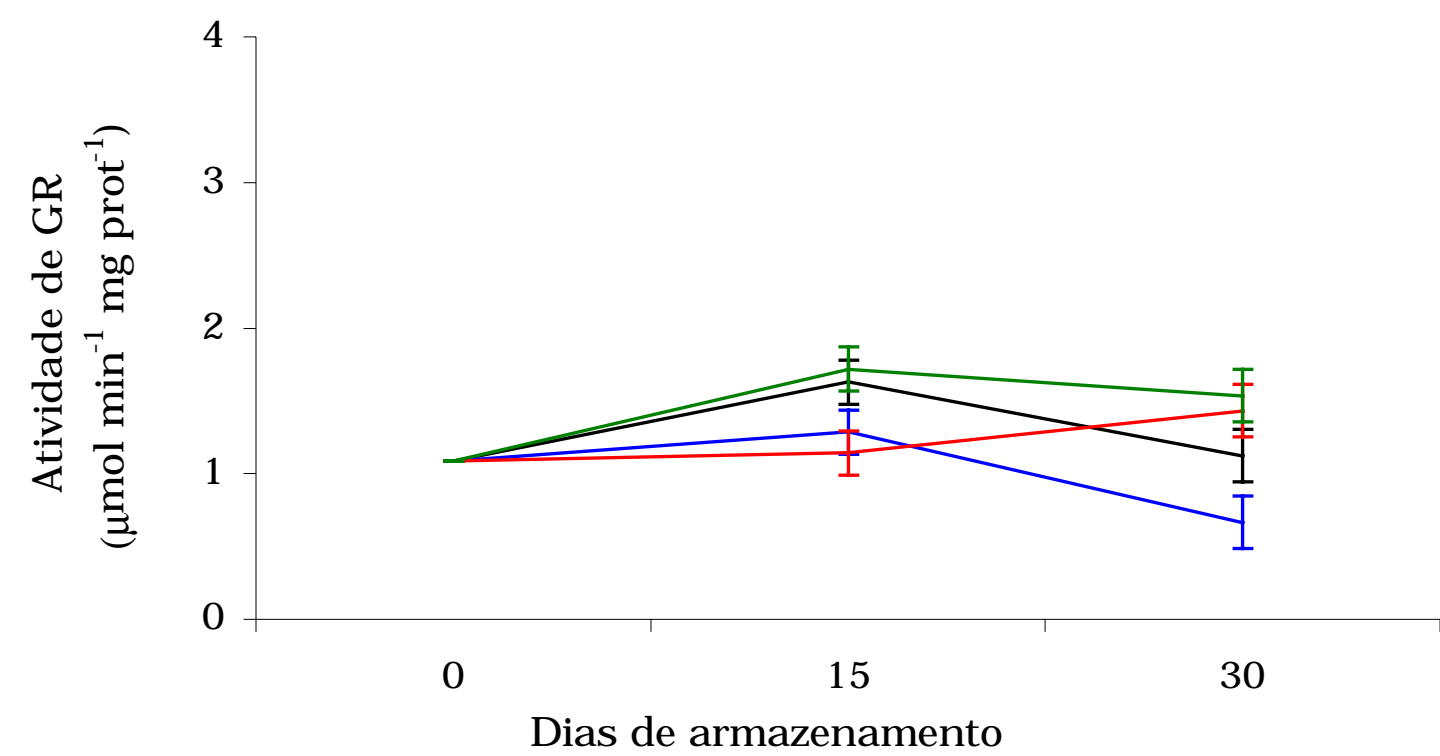

- T1(controle)

— T3(aquecimento lento)
— T2(aquecimento rápido)

— T4(aquecimento intermitente)

Figura 15 - Atividade específica da Glutationa Redutase (GR) em lima ácida 'Tahiti' armazenada a $1^{\circ} \mathrm{C}$. As barras verticais representam o desvio padrão da média 
As peroxidases catalisam a oxidação do substrato utilizando o poder oxidante de $\mathrm{H}_{2} \mathrm{O}_{2}$, ou peróxidos orgânicos. As isoenzimas diferem em sua capacidade por distintos substratos. De acordo com o observado para uma das peroxidases analisada, a ascorbato peroxidase (APX), os resultados foram bastante evidentes no aumento da atividade desta enzima dos frutos que foram submetidos ao aquecimento rápido aos 15 dias de armazenamento, e frutos que foram submetidos ao aquecimento intermitente aos 30 dias de armazenamento (Figura 16). Esse resultado era esperado, pois se consegue estabelecer a relação entre as enzimas antioxidantes e a indução da resistência ao frio pelos tratamentos térmicos.

Até 15 dias de armazenamento a $1^{\circ} \mathrm{C}$, os frutos submetidos ao aquecimento lento não diferiram do controle, os quais obtiveram o mesmo índice de injúria pelo frio. Já os frutos submetidos ao aquecimento rápido obtiveram maior atividade de APX, podendo estar associada a menor incidência pelo frio. Os frutos submetidos ao aquecimento intermitente tiveram um aumento da atividade da APX, aos 30 dias de armazenamento a $1^{\circ} \mathrm{C}$. De fato, a alta atividade de APX permite a maior remoção de $\mathrm{H}_{2} \mathrm{O}_{2}$ que é tóxico à célula (Sminorff, 1993), aumentando, assim, a resistência dos frutos à baixa temperatura. 


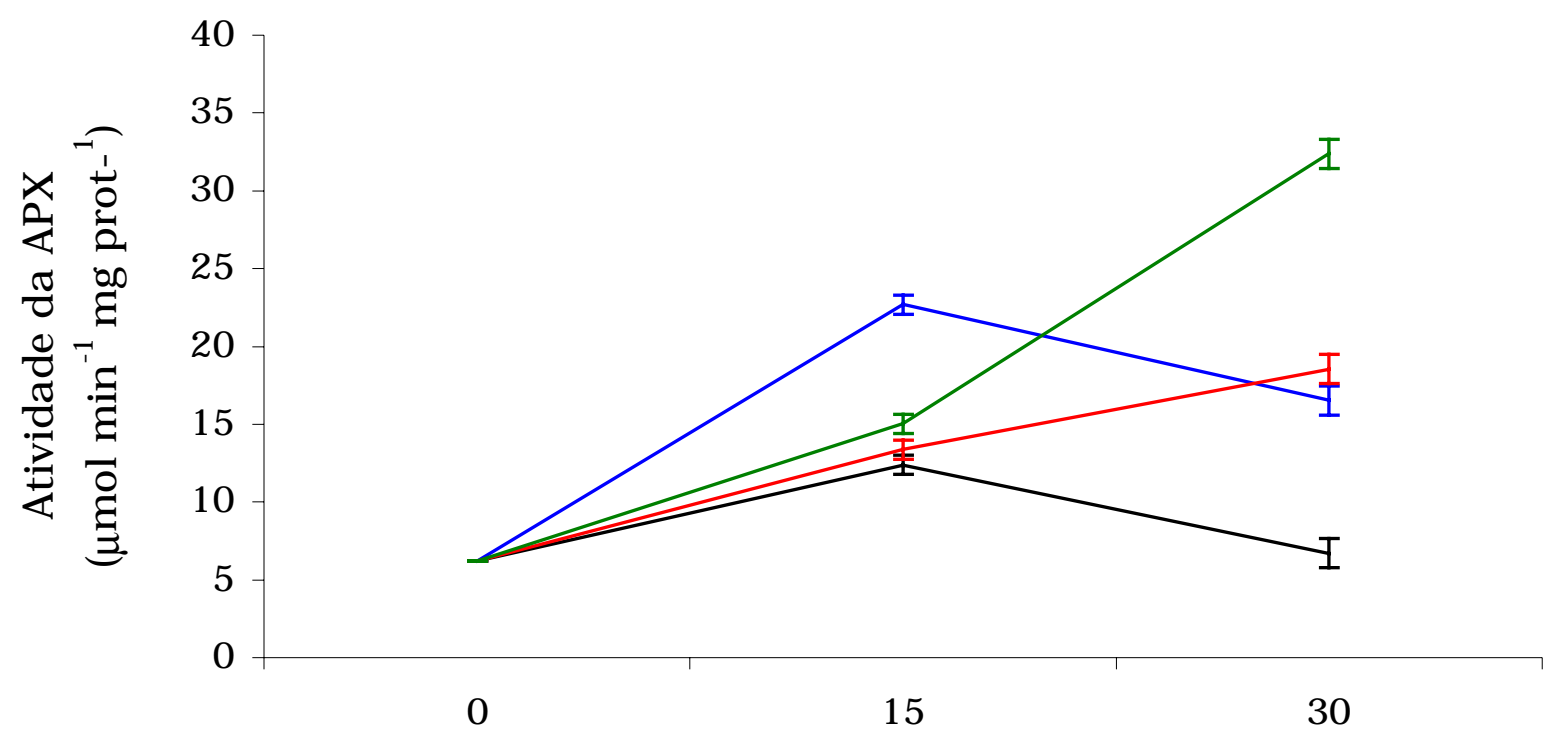

Dias de armazenamento

- T1(controle)

— T3(aquecimento lento)
— T2(aquecimento rápido)

— T4(aquecimento intermitente)

Figura 16 - Atividade específica da ascorbato peroxidase (APX) em lima ácida 'Tahiti' armazenada a $1{ }^{\circ} \mathrm{C}$. As barras verticais representam o desvio padrão da média

De modo geral, observa-se que os frutos que sofreram o aquecimento intermitente não apresentarem incidência de injúria pelo frio, estando associado às maiores atividades das enzimas antioxidantes, principalmente CAT e APX, responsáveis pela remoção do peróxido de hidrogênio, ao longo do armazenamento. Segundo Sala \& Lafuente (2000 e 1999) e Martínez-Telléz \& Lafuente (1997), as enzimas antioxidantes estão associadas à resistência dos frutos à baixa temperatura, assim como demonstrado em pêra por Ju et al. (1994). 


\section{Poliaminas}

Os resultados das análises de poliaminas estão apresentados abaixo nas Figuras 17, 18 e 19, respectivamente, putrescina (Put), espermidina (Spd) e espermina ( $\mathrm{Spm})$.

Observa-se que houve uma tendência de diminuição no teor de poliaminas para os tratamentos térmicos, demonstrando que ao longo do armazenamento há um decréscimo dos teores. De fato isso é coerente, pois com a senescência dos frutos diminui o teor de poliaminas (Barrachina et al., 2000). Porém os frutos do controle houve aumento no teor de Put e Spd, podendo estar relacionado com a condição de estresse pelo frio. Segundo Faust \& Wang (1992), a biossíntese de poliaminas é estimulada sob condições de estresse.

No presente trabalho não foi possivel relacionar os teores de poliaminas com a resistência dos frutos à baixa temperatura. Por outro lado, Lima (2000) observou níveis altos de espermidina e espermina em frutas de bananeira mantidas em baixa temperatura e esse fato pode ser atribuído a efetividade das poliaminas em proteger contra as injurias causadas pelo frio e a efetividade corresponde ao número de cargas por molécula (Galston \& Kaur-Sawhney, 1988).

De fato, as poliaminas, na sua forma livre, têm sido descritas como agentes anti-senescente e o principal efeito tem sido relatado como retartante de alterações de coloração, aumento na firmeza dos frutos, atraso na produção e emissão de etileno e respiração, indutora de resistência a danos mecânicos e redutoras de sintomas de injúrias por baixa temperatura (Valero et al., 1999; Valero et al., 2002). Geralmente, em baixa temperatura, frutos podem apresentar sintomas de injúrias pelo frio, e as poliaminas, como já descrito por inúmeros autores na 
literatura, tendem a proteger as membranas (Jacob \& Stetler, 1991; Bouchereau et al., 1999; Valero \& Serrano, 2002).

Injúrias causadas por baixa temperatura resultaram numa alteração nos níveis de putrescina, numa ampla variedade de frutos e vegetais (Kramer \& Wang, 1989; 1989). Em várias espécies, o aumento de poliaminas estaria correlacionado com a redução das injúrias causadas por este tipo de estresse (Wang \& Ji, 1989; Kramer \& Wang, 1989, 1989). Estes resultados são consistentes com a sugestão que as poliaminas preservam a integridade da membrana, resultando num aumento da viabilidade da célula durante o estresse causado pela baixa temperatura.

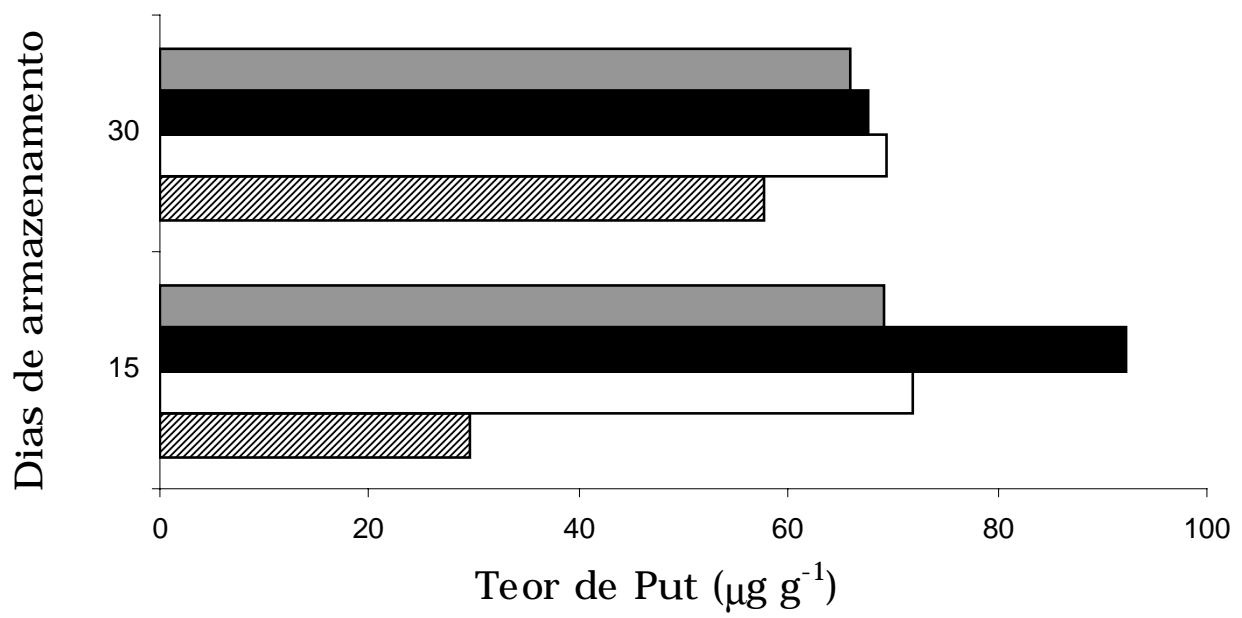

T1(controle)

-T3(aquecimento lento) $\square \mathrm{T} 2$ (aquecimento rápido) $\square \mathrm{T} 4$ (aquecimento intermitente)

Figura 17 - Teor de Putrescina (Put) em casca de lima ácida 'Tahiti' armazenada a $1^{\circ} \mathrm{C}$ em função de diferentes tratamentos 


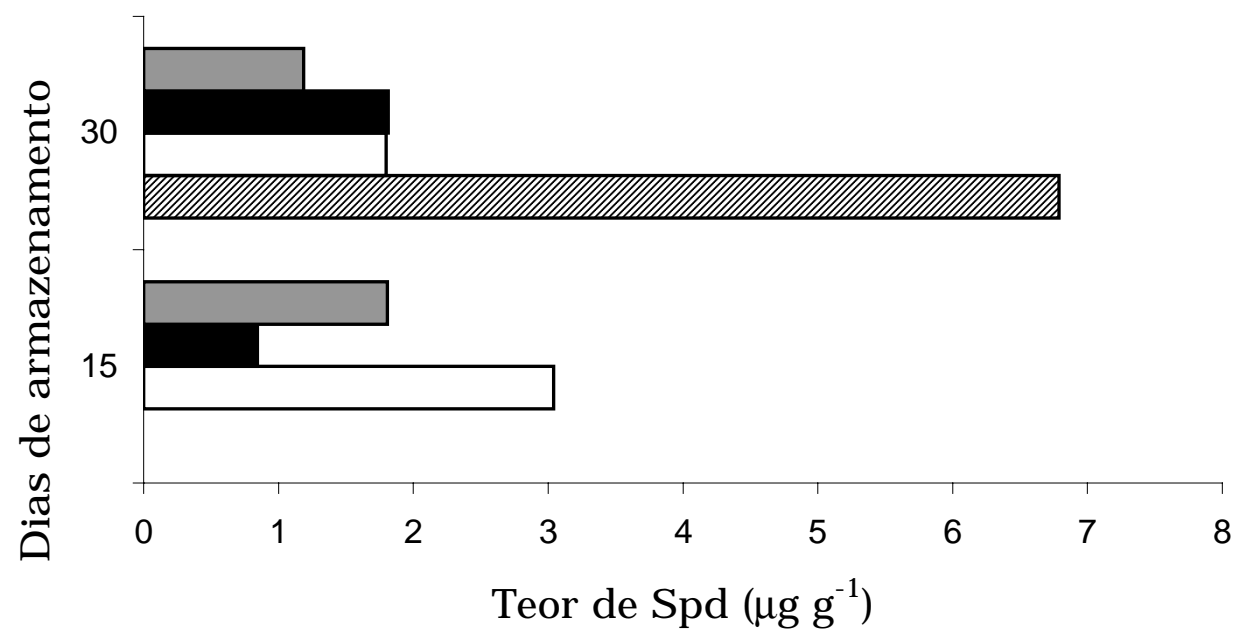

שT1(controle)

aT3(aquecimento lento)

T2(aquecimento rápido)

$\square \mathrm{T} 4$ (aquecimento intermitente)

Figura 18 - Teor de Espermidina (Spd) em casca de lima ácida 'Tahiti' armazenada a $1^{\circ} \mathrm{C}$ em função de diferentes tratamentos

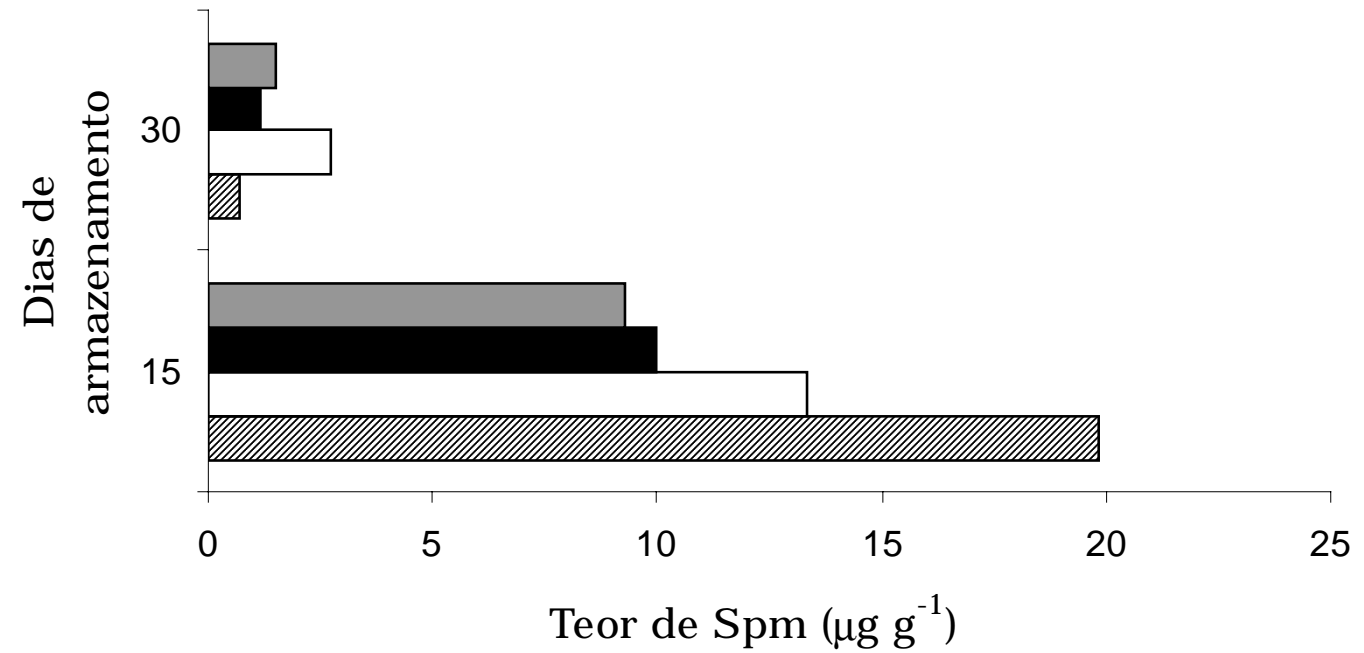

T1(controle)

$\square$ T2(aquecimento rápido)

T3(aquecimento lento)

$\square$ T4(aquecimento intermitente)

Figura 19 - Teor de Espermina (Spm) em casca de lima ácida 'Tahiti' armazenada a $1^{\circ} \mathrm{C}$ em função de diferentes tratamentos 


\subsection{Conclusão}

O tratamento térmico é um método eficiente para aumentar a resistência de lima ácida 'Tahiti'.

Os frutos submetidos ao aquecimento intermitente (ciclos de 6 dias a $1^{\circ} \mathrm{C}+1$ dia a $25^{\circ} \mathrm{C}$ ) apresentaram baixa incidência de injúria pelo frio, não alterando a qualidade dos frutos, pois apresentaram menor redução no teor de ácido ascórbico, bem como menor produção de etileno e menor taxa respiratória. Essa resistência esta associada às atividades das enzimas antioxidantes, principalmente à atividade de CAT e APX.

Os frutos submetidos ao condicionamento térmico rápido $\left(53^{\circ} \mathrm{C} / 3\right.$ min) mantiveram a qualidade dos frutos somente até 15 dias do armazenamento refrigerado, associada à atividade de APX.

Os frutos submetidos ao condicionamento térmico lento $\left(37^{\circ} \mathrm{C} / 2\right.$ dias) não diferiram dos frutos do controle. 


\section{ENVOLVIMENTO DO ETILENO NO DESENVOLVIMENTO DE RESISTÊNCIA DE LIMA ÁCIDA 'TAHITI' À BAIXA TEMPERATURA}

\section{Resumo}

Frutos de lima ácida 'Tahiti' forma submetidos a tratamento estimulador da produção de etileno (aplicação de ethephon) e tratamentos supressores da da produção de etileno (aplicação de ácido salicílico) e da ação do etileno (aplicação de 1-metilciclopropeno) para avaliar o desenvolvimento da resistência a baixa temperatura. Após os tratamentos os frutos foram armazenados em temperatura indutora de sintomas de injúrias pelo frio. $O$ delineamento experimental foi inteiramente ao acaso com 4 repetições de 10 frutos por parcela por tratamento. Foram determinadas a incidência de injúrias pelo frio, a taxa de produção de etileno, os níveis de poliaminas e a atividade de enzimas anti-oxidativas. O trabalho também determinou a taxa respiratória e análise tecnológica. Verificou que todos os frutos apresentaram danos pelo frio a partir de 15 dias de armazenamento a $1^{\circ} \mathrm{C}$, não observando correlação do etileno com a resistência a baixa temperatura, nem com a atividade enzimática antioxidante e teor de poliaminas.

Palavras-chave: Citrus latifolia Tanaka, 1-MCP, ethephon, ácido salicílico, injúria pelo frio. 


\section{ETHYLENE INVOLVEMENT IN THE DEVELOPMENT OF RESISTANCE OF 'TAHITI' LIME AT LOW TEMPERATURE}

\section{Summary}

Fruit of 'Tahiti' lime were submitted the promoter of ethylene production (application of ethephon) and inhibitor ethylene production (application of salicylic acid) and inhibitor of ethylene action (application of 1-metylcyclopropene) to evaluate the development of the resistance low temperature. After the treatments, fruit were stored at $1{ }^{\circ} \mathrm{C}$ during 45 days. It was used the completely randomized design with 4 replicates for treatment, and 10 fruits in each replicate. Incidence of chilling injuries, ethylene production, polyamines content and antioxidants enzymes activity were evaluated. The study also determined the rate respiratory and technological analysis. It observed that all fruit had presented chilling injury from 15 days of cold storage $1^{\circ} \mathrm{C}$. It wasn't possible to verify the correlation between ethylene and low temperature resistance, neither ethylene with the antioxidants enzymes activity and polyamines content.

Key words: Citrus latifolia Tanaka, 1-MCP, ethephon, salicylic acid, chilling injury.

\subsection{Introdução}

A produção de lima ácida 'Tahiti' vem crescendo e ocupando lugar cada vez mais importante na citricultura brasileira, com sua exportação em ascensão, além do consumo interno, visto tratar-se de uma 
variedade que satisfaz plenamente as exigências do mercado consumidor, quanto à qualidade do suco, ao sabor, ao tamanho do fruto e à ausência de sementes (Barros et al., 1991).

As condições recomendadas para a conservação refrigerada de lima ácida 'Tahiti' são temperatura entre 10 a $12^{\circ} \mathrm{C}$ e umidade relativa (UR) entre $85-95 \%$. Sob tais condições os frutos podem ser armazenados por 4 a 8 semanas. Longos períodos de temperatura abaixo de $8^{\circ} \mathrm{C}$ induzem o aparecimento de injúrias pelo frio, caracterizadas por depressões superficiais e aumento na incidência de doenças (Hardenburg et al., 1986; Chitarra \& Chitarra, 1990; Kader \& Arpaia, 1992; Kluge et al., 2001).

Segundo Inzé \& Van Montague (1995) temperaturas extremas podem ser muito estressante para plantas, resultando em um estresse oxidativo, ou seja, formação de espécies ativas de oxigênio (superóxido e peróxido de hidrogênio), que são danosos à célula, pois o peróxido de hidrogênio é uma molécula permeável a membrana acarretando em morte celular. Essa molécula se destaca como um sinalizador intercelular de estresse, como descrito por Prasad et al. (1994).

Os frutos cítricos são considerados não climatéricos e produzem pequena quantidade de etileno. Entretanto, aplicação de etileno e, possivelmente, o etileno endógeno, pode estar envolvido na regulação da maturação e senescência do fruto (Porat et al., 1999).

O envolvimento do etileno sobre a manifestação de injúrias pelo frio em frutos ainda é objeto de estudo. Por exemplo, abacates tratados com etileno ou expostos ao hormônio apresentaram mais desenvolvimento de injúrias pelo frio do que frutos não tratados ou não expostos (Chaplin et al., 1983; Lee \& Young, 1984). Yuen et al. (1995) observaram que a aplicação de etileno $\left(0,005\right.$ a $\left.10 \mu \mathrm{L} \mathrm{L}^{-1}\right)$ em lima 'Tahiti', tangerina ‘Emperor', pomelo ‘Marsh' e laranja 'Valência' resultou 
em aumento nas injúrias pelo frio nos frutos armazenados a $0^{\circ} \mathrm{C} . \quad \mathrm{Em}$ laranjas 'Shamouti' foi verificado que a aplicação de etileno antes do armazenamento refrigerado aumentou a incidência de danos pelo frio nos frutos (Porat et al., 1999). Por outro lado, tem sido observado também que o etileno pode aliviar as injúrias pelo frio, como em melões 'Honeydew' (Lipton \& Aharoni, 1979) e em batata doce (Buescher, 1977), ou não afetar o desenvolvimento das injúrias, como observado em tomates (Kader \& Morris, 1975).

O objetivo deste trabalho foi verificar o envolvimento do etileno no desenvolvimento do mecanismo de resistência dos frutos de lima ácida ‘Tahiti’ à baixa temperatura.

\subsection{Material e Métodos}

Frutos de lima ácida 'Tahiti' foram colhidos em pomar comercial localizado no município de Mogi-Mirim, SP e transportadas ao Laboratório de Fisiologia Pós-colheita do Departamento de Ciências Biológicas da ESALQ/USP. Os frutos tinham a coloração verde-intensa, com diâmetro médio de $6 \mathrm{~cm}$.

\section{Tratamentos}

Os tratamentos foram assim distribuídos:

Tratamento 1: Frutos sem tratamento e armazenados a $1^{\circ} \mathrm{C}$ (Controle). Tratamento 2: Aplicação de ethephon (ácido 2-cloroetilfofônico): os frutos foram submersos em solução com ethephon (2000 $\mathrm{mg} \mathrm{\textrm {L } ^ { - 1 } )}$ durante 5 minutos. Após, sofreram secagem e foram armazenados a $1^{\circ} \mathrm{C}$. 
Tratamento 3: Aplicação de 1-MCP (1-metilciclopropeno): os frutos foram colocados em câmaras hermeticamente fechadas a $25^{\circ} \mathrm{C}$ contendo 1 -MCP $\left(1000 \mathrm{~nL} \mathrm{~L}^{-1}\right)$, onde permaneceram durante 12 horas. Após o tratamento os frutos foram armazenados a $1^{\circ} \mathrm{C}$.

Tratamento 4: Aplicação de Ácido Salicílico: os frutos foram submersos em solução com Ácido Salicílico (2000 mg L-1). Após, sofreram secagem e foram armazenados a $1^{\circ} \mathrm{C}$.

Tratamento 5: Aplicação de 1-MCP (1000 nL L-1) + Ácido Salicílico (2000 mg L-1). Após a aplicação do Ácido Salicílico (2000

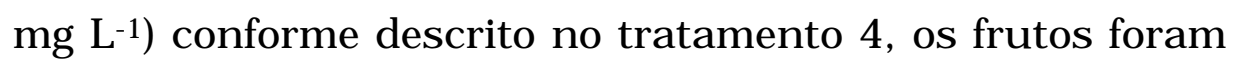
submetidos a aplicação de 1-MCP (1000 nL L-1), conforme descrito no tratamento 3. Após os tratamentos foram armazenados a $1^{\circ} \mathrm{C}$.

Os frutos foram armazenados a $1^{\circ} \mathrm{C}$ em câmaras frias do Departamento de Produção Vegetal (ESALQ/USP), por períodos de 15, 30 e 45 dias, sendo que após cada período de armazenamento, foram expostos à temperatura ambiente $\left(25^{\circ} \mathrm{C}\right)$ por 3 dias, para simular uma comercialização.

\section{Determinações}

\section{Injúrias pelo frio}

A incidência de injúrias pelo frio foi determinada de acordo com a metodologia adaptada de Sala \& Lafuente (1999). De acordo a superfície da casca afetada os frutos foram classificados em cinco categorias: $0=$ sem depressões superficiais ( $0 \%$ da superfície afetada), $1=$ pouco ( 1 a $5 \%$ da superfície afetada), $2=$ médio (5-25\%) e 3 = severo $(25-50 \%)$ e $4=$ muito severo (> 50\% da superfície afetada). 
2. Produção de etileno

Para a determinação da produção de etileno, os frutos foram colocados em frascos de vidro com capacidade de $500 \mathrm{~mL}$, preenchendo o espaço vazio com bolinha de vidro, permanecendo hermeticamente fechados por períodos de 2 horas. Em cada tampa dos jarros foi colocado um septo de borracha através do qual foi retirada a amostra de gás. Com uma seringa de $1 \mathrm{~mL}$ foi coletada uma amostra de cada jarro e injetada em cromatógrafo a gás. Os resultados foram expressos em $\mu \mathrm{L}$ $\mathrm{C}_{2} \mathrm{H}_{4} \mathrm{~kg}^{-1} \mathrm{~h}^{-1}$. Foram utilizados 1 frutos por frasco. Esta determinação foi realizada após a comercialização simulada de 3 dias a $25^{\circ} \mathrm{C}$.

\section{Taxa respiratória}

O procedimento foi semelhante ao anterior no que se refere à coleta da amostra de gás. A amostra foi injetada em cromatógrafo a gás. Os resultados foram expressos em $\mathrm{mg} \mathrm{CO} 2 \cdot \mathrm{kg}^{-1} \cdot \mathrm{h}^{-1}$.

\section{Análise de poliaminas}

As poliaminas foram determinadas seguindo a técnica modificada de Smith (1991) e Lima et al. (1999). Amostras previamente pesadas foram homogeneizadas em ácido perclórico 5\% gelado (100 mg/mL), deixadas por 1 hora em banho de gelo e centrifugadas a 12000 G por 20 minutos. O sobrenadante contendo poliaminas livres foi usado para dansilação. Cloreto de dansila (5-[diametilamino] naftaleno 1-sulfonil (cloreto)) - Sigma; $400 \mathrm{ml}$ de uma solução de $5 \mathrm{mg} / \mathrm{mL}$ acetona e $200 \mathrm{ml}$ de $\mathrm{Na}_{2} \mathrm{CO}_{3}$ saturado, foram adicionados a $200 \mathrm{ml}$ do sobrenadante. Após agitação, a mistura permaneceu em temperatura ambiente, no escuro, por 16 horas. As poliaminas foram extraídas com $500 \mathrm{ml}$ de benzeno e a fase orgânica foi usada para determinação por cromatografia de camada delgada, em placas recobertas por sílica gel 60G (Merck). Como 
fase móvel foi utilizada clorofórmio-trietilamina (25:2 v/v). Quantidades conhecidas de padrões de poliaminas foram dansiladas e cromatografadas da mesma maneira. A determinação quantitativa das poliaminas foi realizada em densitômetro (Helena). Os teores de poliaminas livres (putrescina, espermidina e espermina) foram expressos em $\mu g g^{-1}$ de massa fresca.

5. Determinação da atividade das enzimas antioxidativas

Foram determinadas as atividades das enzimas catalase, superóxido dismutase, ascorbato peroxidase e glutationa redutase.

Foi utilizado como material vegetal para a análise das enzimas a casca dos frutos, onde foi coletado somente tecido sadio, retirando as partes lesionadas. A coleta do material foi feita logo após a retirada dos frutos da câmara fria, aos 15 e 30 dias de armazenamento refrigerado, logo em seguida foram congelados em Nitrogênio líquido.

Os materiais vegetais foram macerados em nitrogênio líquido até a formação de uma farinha. Logo em seguida foram homogeneizados em tampão (extração) fosfato de potássio $100 \mathrm{mM}(\mathrm{pH} 7,5)$ contendo $1 \mathrm{mM}$ de EDTA (0,372g/L tampão), 3mM de DTT $(0,462 \mathrm{~g} / \mathrm{L}$ tampão) e 4\% (p/v) de PVPP.

O homogeneizado foi centrifugado a $10.000 \mathrm{rpm}$ por $30 \mathrm{~min}$ à $4^{\circ} \mathrm{C}$. O sobrenadante foi coletado, dividido em alíquotas e, estas, estocadas em freezer $-80^{\circ} \mathrm{C}$ até o momento das análises.

A análise das enzimas foi realizada por atividade em géis não denaturantes (poliacrilamida 8-10\%) e por espectrofotometria, dependendo da enzima e de acordo com a descrição que se segue.

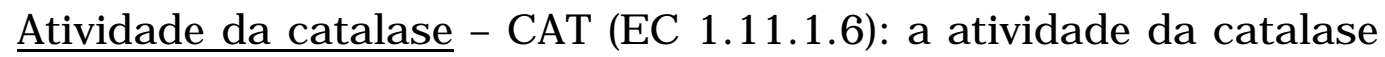
foi determinada como descrito por Kraus et al. (1995) com algumas 
modificações de acordo com Azevedo et al. (1998). A CAT é determinada espectrofotometricamente a $25^{\circ} \mathrm{C}$ em uma mistura de reação contendo $1 \mathrm{~mL}$ de tampão fosfato de potássio $(100 \mathrm{mM}) \mathrm{pH} 7,5$ contendo $2,5 \mu \mathrm{L}$ de peróxido de hidrogênio (solução de 30\%) preparada imediatamente antes do uso. A reação foi iniciada pela adição de $15 \mu \mathrm{L}$ de extrato e a atividade foi determinada seguindo-se a decomposição de peróxido de hidrogênio por $1 \mathrm{~min}$, por alterações na absorbância a 240 ๆm.

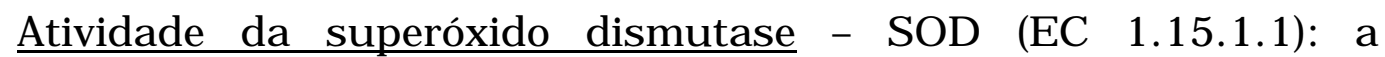
atividade foi determinada por eletroforese, que foi conduzida à $4^{\circ} \mathrm{C}$ e, após a separação das proteínas, os géis foram enxaguados rapidamente em água destilada-deionizada e incubados no escuro a temperatura ambiente em uma mistura de reação contendo $50 \mathrm{mM}$ de tampão fosfato de potássio $\mathrm{pH}$ 7,8, $1 \mathrm{mM}$ EDTA, 0,05 $\mathrm{mM}$ riboflavina, 0,1 $\mathrm{mM}$ nitroblue tetrazolium e 0,3\% TEMED. Ao final de $30 \mathrm{~min}$, a mistura de reação foi removida, os géis enxaguados com água destilada-deionizada e colocados sob iluminação por alguns minutos até o desenvolvimento de bandas brancas sob fundo roxo. SOD bovina (Sigma) foi sempre corrida no gel como padrão interno positivo para atividade de SOD.

Atividade da Ascorbato peroxidase - APX (EC 1.11.1.11) Foi utilizada a metodologia de Nakano \& Asada (1981). A mistura da reação

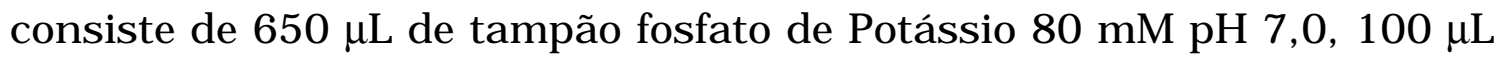
Ascorbato $(5 \mathrm{mMO}, 100 \mu \mathrm{L}$ EDTA ( $1 \mathrm{mM})$ e $100 \mu \mathrm{L}$ peróxido de hidrogênio (1mM). A reação foi iniciada com a adição de $50 \mu \mathrm{L}$ do extrato vegetal. A atividade foi determinada seguindo-se a decomposição de peróxido de hidrogênio por 1 min, por alterações na absorbância a 290 ๆm. 
$\underline{\text { Atividade da glutationa redutase }}$ - GR (EC 1.6.4.2.) Foi determinada espectrofotometricamente a $30^{\circ} \mathrm{C}$ em uma mistura de reação consistindo de $3 \mathrm{~mL}$ tampão fosfato de potássio (100 mM) pH 7,5 contendo $1 \mathrm{mM}$ 5,5'-dithio-bis (2-nitrobenzoic acid), $1 \mathrm{mM}$ glutationa oxidada e 0,1 mM NADPH. A reação foi iniciada pela adição de 25-50 $\mu \mathrm{L}$ de extrato. GR foi estimada pela redução de glutationa oxidada que foi acompanhada por monitoramento na alteração da absorbância a 412 $\eta \mathrm{m}$.

Determinação de proteína - O método de Bradford foi utilizado para as determinações da concentração de proteínas totais, utilizandose o BSA como padrão.

As atividades específicas foram calculadas a partir da quantidade de proteína total:

Atividade específica de catalase:

[atividade de CAT $]=\frac{[\text { Leitura }(\mathrm{Abs}) / 39400]}{[\text { Teor de prot } / 40]} \times 10^{6}=(\mu \mathrm{mol} / \mathrm{min} / \mathrm{mg} \operatorname{prot})$

Atividade específica de ascorbato peroxidase:

[atividade de APX] $=\frac{[\text { Leitura (Abs) } x \text { coef.ext }] \times 60}{[\text { Teor de prot }]}=(\mu \mathrm{mol} / \mathrm{min} / \mathrm{mg}$ prot $)$

Atividade específica de glutationa redutase:

[(Leitura (Abs)+0,0134)/1,938]

[atividade de GR] $=$ $=(\mu \mathrm{mol} / \mathrm{min} / \mathrm{mg}$ prot $)$

[Teor de prot/40] 
6. Porcentagem de suco

Cada repetição foi pesada e extraído o suco dos frutos. A porcentagem de suco foi calculada através da fórmula: \% de suco = $(\mathrm{MS} / \mathrm{MF}) \times 100$, onde $\mathrm{MS}=$ massa do suco $(\mathrm{g})$ e $\mathrm{MF}=$ massa do fruto.

7. Teor de ácido ascórbico

Uma alíquota de $10 \mathrm{~mL}$ se suco foi colocada em erlenmeyer contendo 50mL de solução de ácido oxálico. A titulação foi efetuada com DCFI até atingir a coloração rosada persistente por 15 segundo. Os resultados foram expressos em mg de ácido ascórbico por 100mL de suco.

8. Coloração da casca

Através do equipamento Minolta Chroma Meter CR-300 foram determinados os valores de ângulo de cor (ho) e chroma $\left(\mathrm{C}^{*}\right)$;

9. Teor de sólidos solúveis totais (SST)

Foi determinado em refratômetro digital, com correção automática de temperatura para $20^{\circ} \mathrm{C}$. Os resultados foram expressos em ${ }^{\circ}$ Brix.

10. Acidez total titulável (ATT)

Para a determinação da acidez total titulável, 10mL do suco foram colocados em 90mL de água destilada. Foi efetuada titulação potenciométrica com $\mathrm{NaOH} 1 \mathrm{~N}$ até $\mathrm{pH} 8,10$. Os resultados foram expressos em \% ácido cítrico.

\section{1. "Ratio"}

Foi calculado pela divisão do teor de SST pela ATT. 
12. Índice tecnológico (I.T.)

Foi calculado através da fórmula: I.T. $=($ SST $x \%$ de suco $) / 100$.

\section{Delineamento experimental e Análise estatística}

O delineamento experimental foi inteiramente ao acaso. Foram utilizadas quatro repetições compostas de 10 frutos. Os resultados coletados foram submetidos à análise de variância (teste $\mathrm{F}$ ) e as médias comparadas por Tukey (5\%), utilizando-se do pacote SAS.

As análises fisiológicas foram avaliadas observando as curvas de respiração e produção de etileno, tais como nas análises das atividades enzimáticas. Os dados foram submetidos à análise de variância e as médias foram comparadas pelo teste de diferença mínima significativa em teste de comparações múltiplas, em que as diferenças entre dois tratamentos maior que a soma de dois desvios padrões foram consideradas significativas ao nível de $5 \%$ de probabilidade (Shamaila et al., 1992).

\subsection{Resultados e Discussão}

As análises foram feitas até 45 dias de armazenamento a $1{ }^{\circ} \mathrm{C}$, com comercialização simulada de 4 dias a $25{ }^{\circ} \mathrm{C}$, pois a partir deste período os frutos não estavam em condições comercializáveis, ou seja, correspondeu a máxima vida de prateleira após a refrigeração.

\section{Injúrias pelo frio}

Um dos maiores problemas que impedem um maior período de conservação e comercialização de lima ácida 'Tahiti' é a danificação 
da casca verde, seja por perda da coloração ou por danos provocados pelo frio que ocasionam manchas marrons na superfície dos frutos. Neste sentido têm-se buscado entender o mecanismo de defesa do fruto e procurar tratamentos adicionais à refrigeração que evitem a perda da integridade da casca verde do fruto.

As injúrias pelo frio começaram a surgir a partir de 15 dias de armazenamento (Figura 20, 21, 22, 23, 24, 25 e 26). Os frutos tratados com 1-MCP (bloqueador da ação do etileno) apresentaram incidência de injúrias pelo frio aos 15 dias de armazenamento, resultado semelhante ao observado em laranjas 'Shamouti' (Porat et al., 1999). Segundo esses autores, o etileno endógeno pode ser necessário para a manutenção dos mecanismos de defesa contra ao dano de frio. Por outro lado, outros autores verificaram que o 1-MCP reduziu o dano pelo frio em produtos como abacate, abacaxi e ameixa (Selvarajah et al., 2001; Pesis et al., 2002; Salvador et al., 2003).

Os frutos tratados com ethephon também apresentaram alta incidência de injúria pelo frio. De fato, a aplicação exógena de etileno ocasionou o maior severidade de dano pelo frio em abacate (Pesis et al., 2002) e mais especificamente em frutas cítricas verificado por Brown \& Lee (1993) e Porat et al. (1999), como visto também em lima ácida 'Tahiti', tangerina 'Emperor' e laranja 'Valência' (Yuen et al., 1995). Após 45 dias estes tratamentos apresentavam 100\% dos frutos afetados.

A aplicação de ácido salicílico não teve diferença quanto à incidência de injúria, em relação ao controle. 


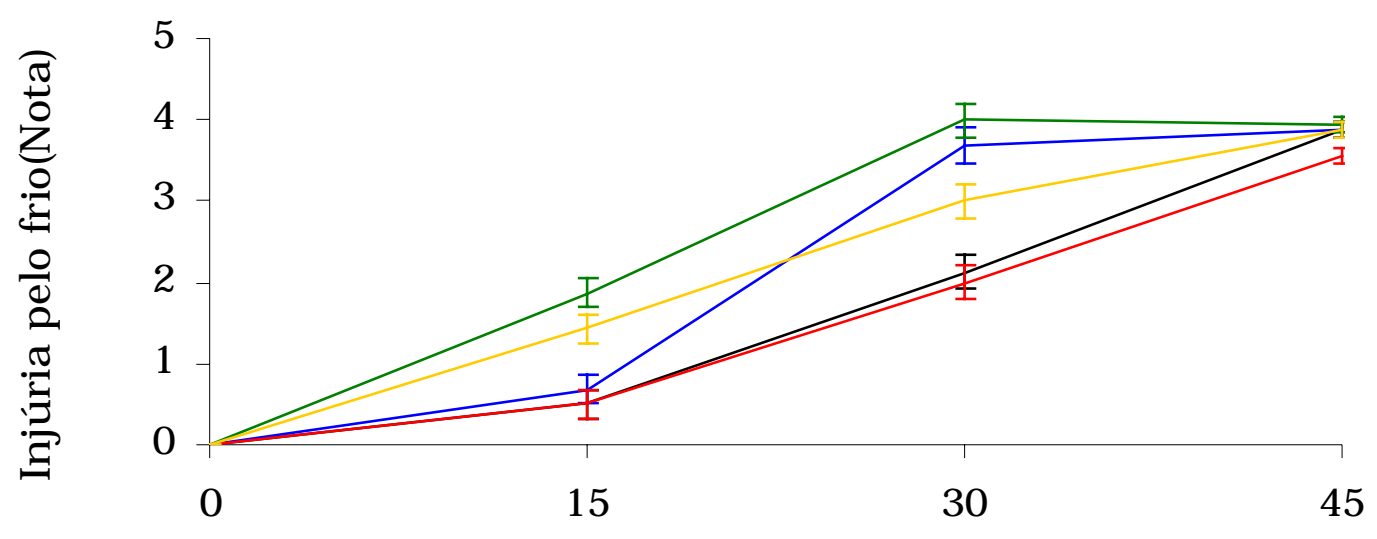

Dias de armazenamento

- T1 - Controle

T3 - 1-MCP

T5 - 1-MCP + Ác. Salicílico
- T2 - Ethephon T4 - Ác. Salicílico

Figura 20 - Efeito dos diferentes tratamentos sobre as injúrias pelo frio (indice de injúrias) em lima ácida 'Tahiti’ armazenada a $1^{\circ} \mathrm{C}$. Notas: $0=$ sem depressões superficiais $10 \%$ da superfície afetada), 1 = pouco ( 1 a 5\% da superfície afetada), 2 = médio $(5-25 \%)$ e 3 = severo (25-50\%) e $4=$ muito severo $(>50 \%$ da superficie afetada). As barras verticais representam o desvio padrão da média

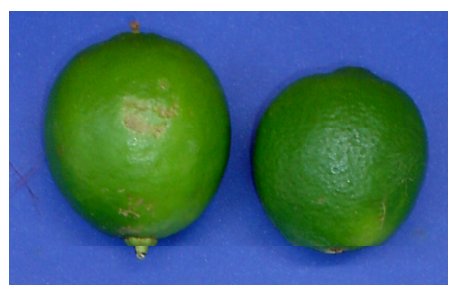

$\mathrm{T} 1$

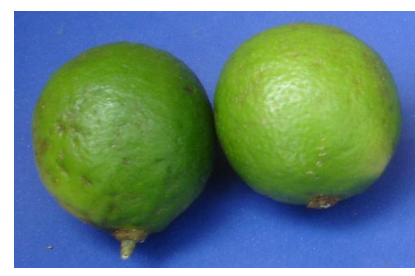

T2

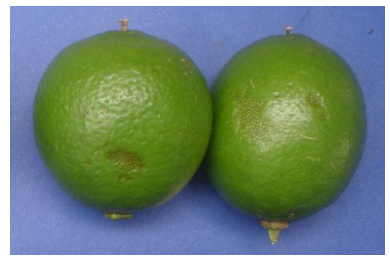

T3

Figura 21 - Frutos do controle (T1); Frutos submetidos à aplicação de Ethephon (T2); Frutos submetidos à aplicação de 1-MCP (T3), aos 15 dias de armazenamento refrigerado +3 dias de comercialização simulada 


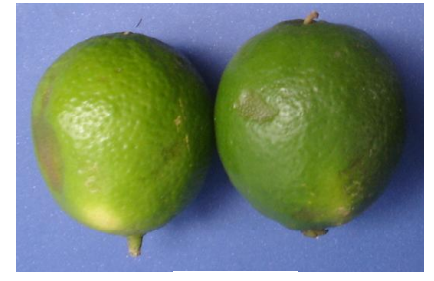

T4

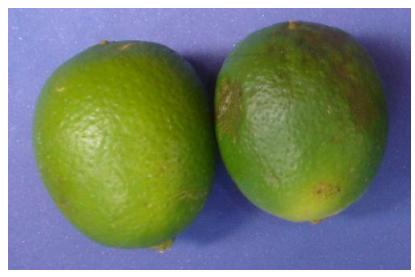

T5

Figura 22 - Frutos submetidos à aplicação de Ácido Salicílico (T4); Frutos submetidos à aplicação de 1-MCP + Ácido Salicílico (T5), aos 15 dias de armazenamento refrigerado +3 dias de comercialização simulada

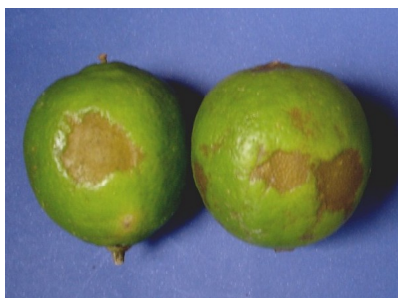

T1

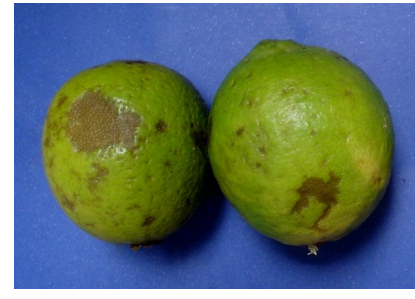

T2

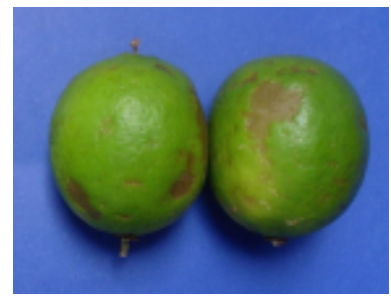

T3

Figura 23 - Frutos do controle (T1); Frutos submetidos à aplicação de Ethephon (T2); Frutos submetidos à aplicação de 1-MCP (T3), aos 30 dias de armazenamento refrigerado +3 dias de comercialização simulada

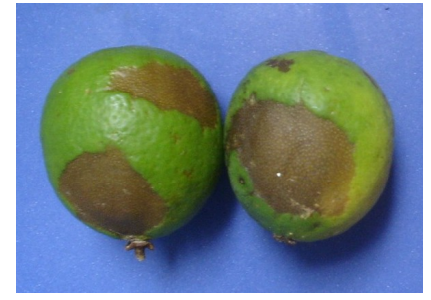

T4

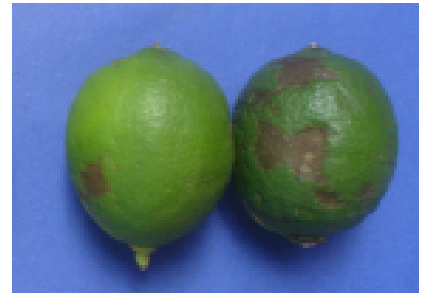

T5

Figura 24 - Frutos submetidos à aplicação de Ácido Salicílico (T4); Frutos submetidos à aplicação de 1-MCP + Ácido Salicílico (T5), aos 30 dias de armazenamento refrigerado +3 dias de comercialização simulada 


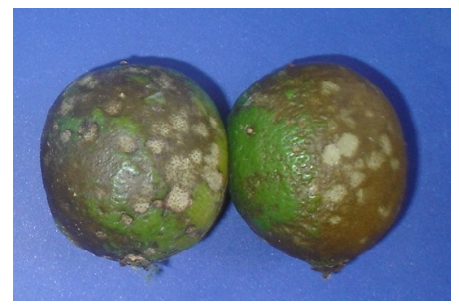

T1

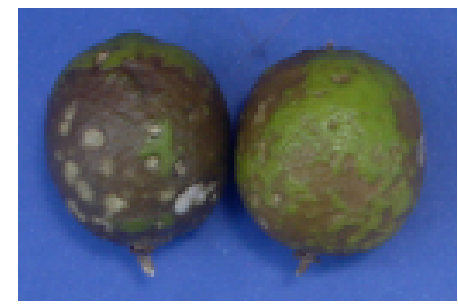

T2

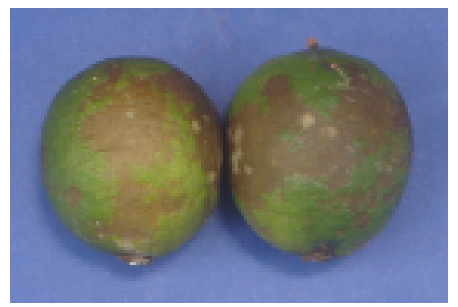

T3

Figura 25 - Frutos do controle (T1); Frutos submetidos à aplicação de Ethephon (T2); Frutos submetidos à aplicação de 1-MCP (T3), aos 45 dias de armazenamento refrigerado +3 dias de comercialização simulada

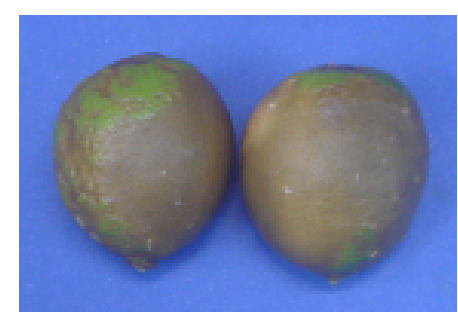

T4

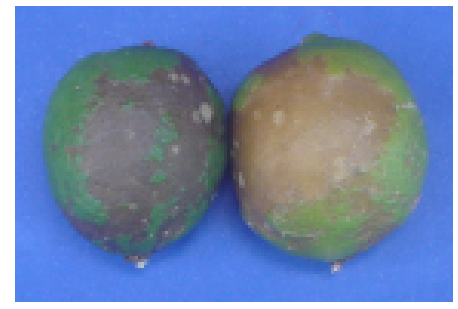

T5

Figura 26 - Frutos submetidos à aplicação de Ácido Salicílico (T4); Frutos submetidos à aplicação de 1-MCP + Ácido Salicílico (T5), aos 45 dias de armazenamento refrigerado +3 dias de comercialização simulada

\section{Produção de etileno}

Os resultados obtidos para a produção de etileno encontram-se na Figura 27. O etileno foi detectado até 45 dias de armazenamento refrigerado a $1{ }^{\circ} \mathrm{C}$, com comercialização simulada de 3 dias a $25{ }^{\circ} \mathrm{C}$, pois a partir deste período os frutos não estavam em condições comercializáveis. 
No tratamento com ethephon foi verificada maior produção de etileno. Outro fator da alta produção de etileno é que, no processo de transformação da metionina em SAM, ocorre o consumo de ATP (Abeles et al., 1997). Este ATP é decorrente da cadeia respiratória. Os frutos tratados com ethephon apresentaram uma alta taxa respiratória, assim produzindo ATP, necessário para a produção de SAM, conseqüentemente elevando a produção de etileno.

Em relação ao tratamento com bloqueador de etileno (1metilciclopropeno), observou-se baixa produção de etileno até 30 dias de armazenamento, o que também é relatado por Blankenship \& Dole (2003).

Após 30 dias de armazenamento à baixa temperatura, aumentou a produção de etileno dos outros tratamentos e dos frutos do controle, conforme verificado em maçã e tomate por Lederman et al. (1997) e Autio \& Bramlage (1986), respectivamente, e em outros cultivares de citros por McCollum \& McDonald (1991), que demonstraram que os frutos que tiveram danos pelo frio aumentaram a produção de etileno.

Segundo Jobling et al. (1991) e Larrigaudiere \& Vendrell (1993), a capacidade de converter ACC em etileno é induzido mais rapidamente à baixa temperatura $\left(0-5{ }^{\circ} \mathrm{C}\right)$. Outro fator da alta produção de etileno, é que no processo de transformação da metionina em SAM ocorre o consumo de ATP (Abeles et al., 1997). Este ATP é decorrente da cadeia respiratória. Os frutos do controle apresentaram uma alta taxa respiratória, produzindo, assim, ATP, necessário para a produção de SAM.

A correlação entre produção de etileno com desenvolvimento de sintomas de injúrias pelo frio parece não existir, uma vez que os frutos mais afetados tiveram produção de etileno bastante diferenciada. Lederman et al. (1997) relataram que uma das alterações marcantes em 
frutos que sofrem injúrias pelo frio é o aumento na produção de etileno, mas esta parece ser uma causa secundária do aparecimento dos sintomas ou ocorre paralelamente.

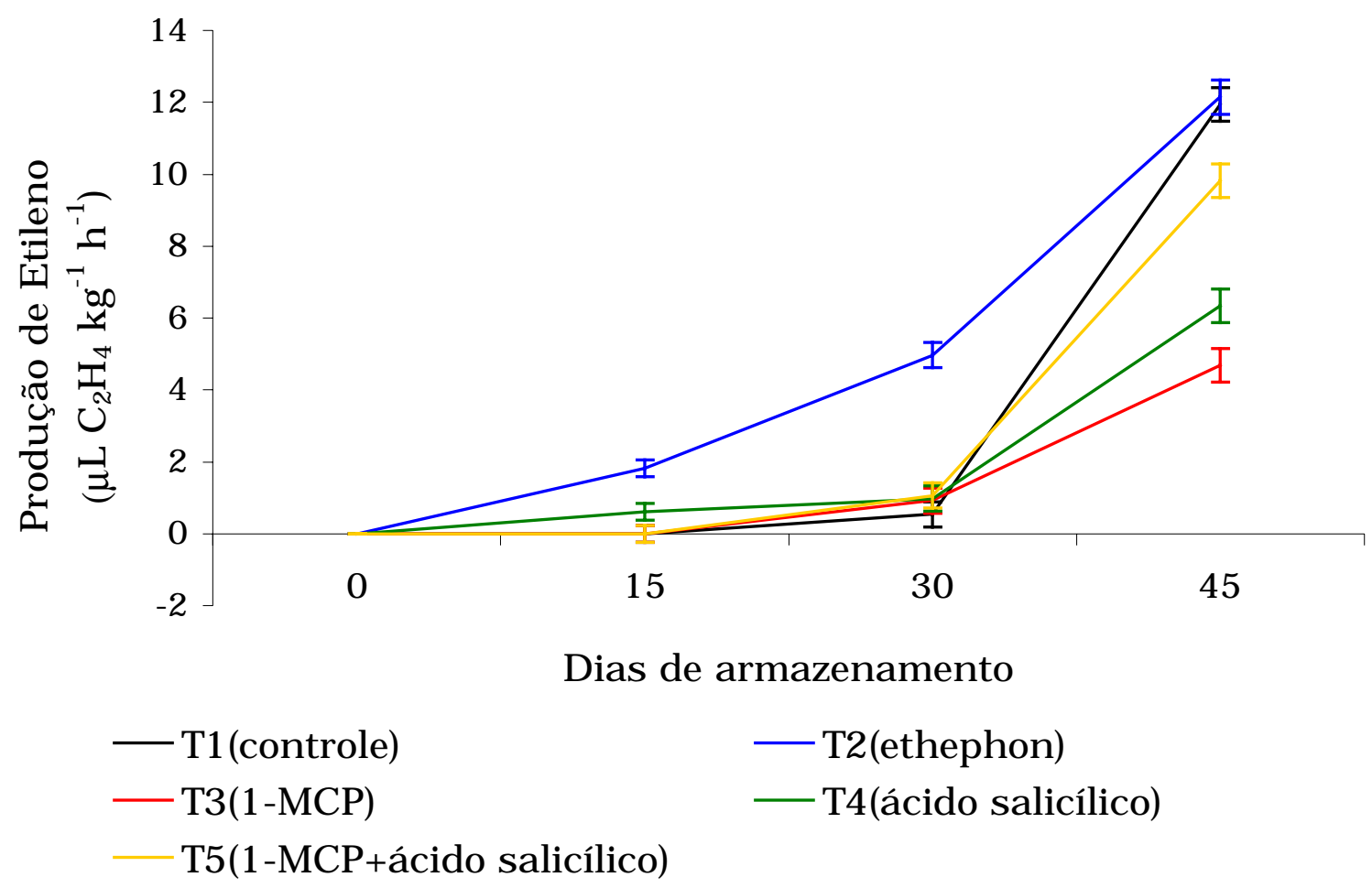

Figura 27 - Efeito dos diferentes tratamentos sobre a produção de etileno em lima ácida 'Tahiti' armazenada a $1^{\circ} \mathrm{C}$. As barras verticais representam o desvio padrão da média

\section{Taxa Respiratória}

Observa-se na Figura 28 que a taxa respiratória aumentou ao longo do armazenamento refrigerado em todos os tratamentos. Esse fato é devido que em todos frutos dos tratamentos apresentaram dano de 
frio. Segundo Fallik (2004), estresse por baixa temperatura aumenta a taxa respiratória.
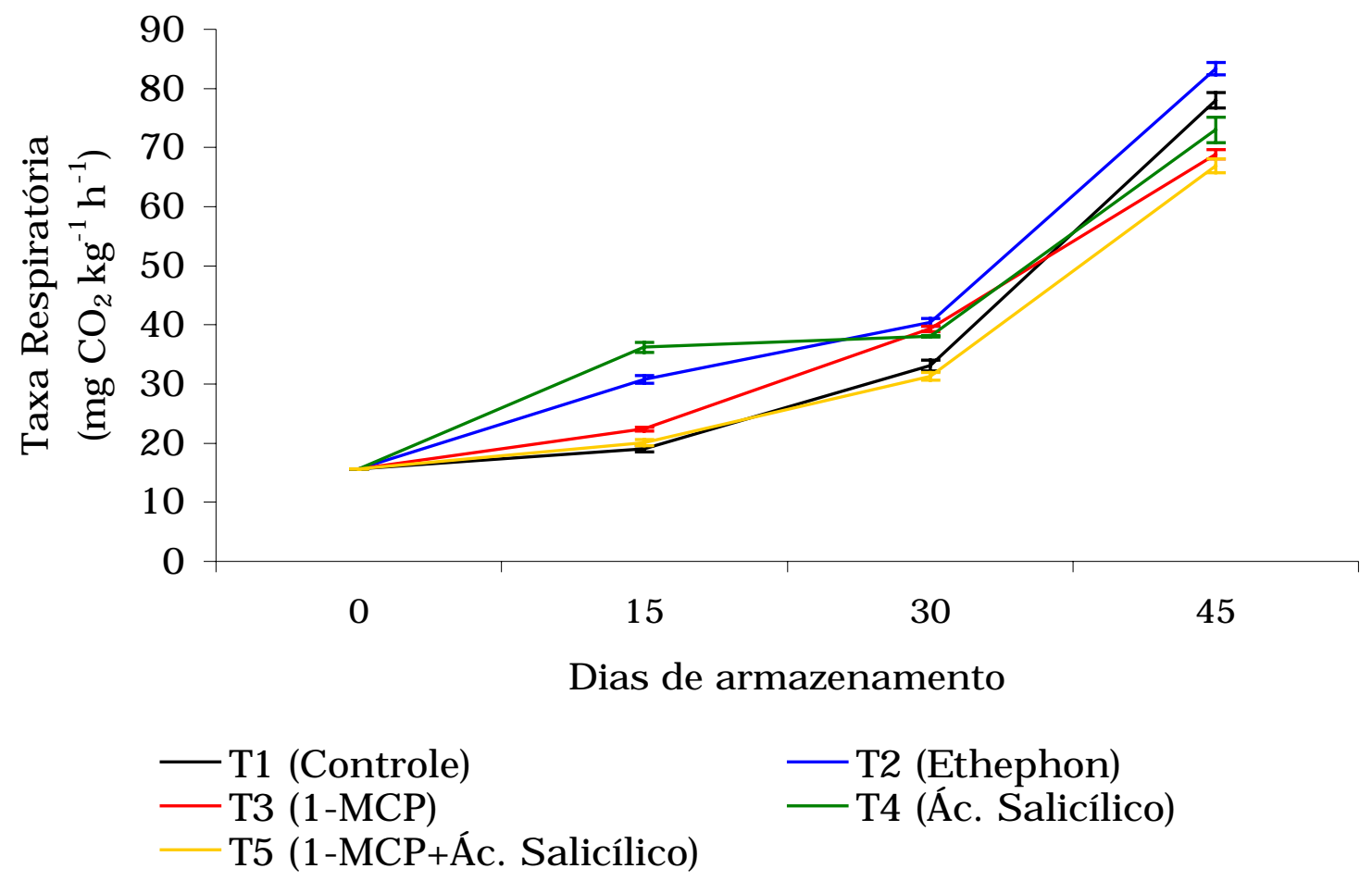

Figura 28 - Efeito dos diferentes tratamentos sobre a taxa respiratória em lima ácida 'Tahiti' armazenada a $1^{\circ} \mathrm{C}$. As barras verticais representam o desvio padrão da média

\section{Avaliação Tecnológica}

Na Tabela 8 estão apresentados os efeitos dos diferentes fatores avaliados no experimento e, observa-se, que houve efeito dos tratamentos ao longo do armazenamento. 
Tabela 8. Significância do teste $\mathrm{F}$ da análise de variância para os efeitos dos diferentes fatores sobre os parâmetros físico-químicos em lima ácida 'Tahiti' submetidas a diferentes tratamentos, armazenada a $1^{\circ} \mathrm{C}$

\begin{tabular}{|c|c|c|c|c|c|c|c|}
\hline $\begin{array}{l}\text { Fontes de } \\
\text { variação }\end{array}$ & \% suco & SST & AT & "Ratio" & I.T. & $\begin{array}{l}\text { Teor Ac. } \\
\text { ascórbico }\end{array}$ & $\operatorname{Cor}\left({ }^{\circ} \mathrm{h}\right)$ \\
\hline $\begin{array}{c}\text { Tratamento } \\
\text { (TR) }\end{array}$ & $* *$ & $* *$ & n.s. & n.s. & $* *$ & $* *$ & $* *$ \\
\hline Tempo (TE) & $* *$ & $* *$ & $* *$ & $* *$ & $* *$ & $* *$ & $* *$ \\
\hline TR $x$ TE & $* *$ & $* *$ & $* *$ & $* *$ & $* *$ & $* *$ & $* *$ \\
\hline C.V. (\%) & 5,67 & 3,16 & 4,36 & 5,45 & 6,39 & 9,93 & 2,18 \\
\hline
\end{tabular}

\section{Porcentagem de suco}

De maneira geral, observa-se que ao longo do armazenamento houve redução na porcentagem de suco (Tabela 9), porém, em alguns tratamentos aos 30 dias de armazenamento houve aumento, fato esse que pode ter sido devido à perda de água, que aumenta a relação de suco sobre a massa total dos frutos, pois a transpiração fica restrita apenas no flavedo, não interferindo a quantidade de suco (Jomori et al., 2003). 
Tabela 9. Porcentagem de suco de lima ácida 'Tahiti' armazenada a $1^{\circ} \mathrm{C}$ em função dos tratamentos ${ }^{1}$

\begin{tabular}{lccccc}
\hline \multicolumn{5}{c}{ Tempo de armazenamento } \\
Tratamentos & 0 dias & 15 dias & 30 dias & 45 dias & Médias \\
\hline & 47,43 a A & 44,14 ab AB & 42,66 a B & 36,01 ab C & 42,56 a \\
T1 & 47,43 a A & 40,25 b B & 45,89 a A & 37,55 a B & 42,78 a \\
T2 & 47,43 a A & 43,77 ab A & 43,07 a A & 36,48 ab B & 42,69 a \\
T3 & 47,43 a A & 43,68 ab A & 44,76 a A & 32,70 b B & 42,15 a \\
T4 & 47,43 a A & 46,69 a A & 46,10 a A & 37,90 a B & 44,53 a \\
T5 & 47,43 A & 43,71 B & 44,50 B & 36,13 C & \\
Médias &
\end{tabular}

${ }^{1}$ Médias seguidas de mesma letra minúscula na coluna e maiúscula na linha não diferem entre si pelo teste de Tukey (5\%).

${ }^{2} \mathrm{~T} 1$ = controle; $\mathrm{T} 2$ = ethephon; $\mathrm{T} 3$ = 1-MCP; $\mathrm{T} 4$ = ácido salicílico; $\mathrm{T} 5$ = 1-MCP + ácido salicílico.

\section{Teor de ácido ascórbico}

De modo geral, observa-se um aumento do teor de ácido ascórbico e depois uma queda ao longo do armazenamento (Tabela 10). Segundo Silva et al. (1998), esse aumento do teor de ácido ascórbico pode ser resultado da produção de precursores do ácido na respiração ou pode estar relacionado com a degradação de pectinas, que libera precursores do ácido ascórbico (Agius et al., 2003). A queda posterior do teor de ácido ascórbico pode estar relacionada com a própria senescência, onde o ácido ascórbico é consumido em reações oxidativas. 
Tabela 10. Teor de ácido ascórbico de lima ácida 'Tahiti' armazenada a $1^{\circ} \mathrm{C}$ em função dos tratamentos ${ }^{1}$

\begin{tabular}{lccccc}
\hline \multicolumn{5}{c}{ Tempo de armazenamento } \\
Tratamentos & 0 dias & 15 dias & 30 dias & 45 dias & Médias \\
\cline { 2 - 5 } T1 & & ------ Ácido Ascórbico(mg/100 ml)------ & \\
T2 & 37,74 a B & 33,79 a AB & 33,77 a AB & 29,12 a B & 33,60 a \\
T3 & 37,74 a B & 35,77 a AB & 30,36 ab BC & 26,84 a C & 32,68 a \\
T4 & 37,74 a A & 34,21 a A & 26,25 b B & 25,38 a B & 30,89 a \\
T5 & 37,74 a A & 37,74 a A & 26,25 b A & 29,20 a B & 32,86 a \\
Médias & 37,74 a B & 32,67 a AB & 28,31 ab B & 28,59 a B & 31,83 a \\
& 37,74 BC & 26,52 B & 30,61 A & 24,69 C & \\
\hline
\end{tabular}

${ }^{1}$ Médias seguidas de mesma letra minúscula na coluna e maiúscula na linha não diferem entre si pelo teste de Tukey (5\%).

${ }^{2} \mathrm{~T} 1$ = controle; $\mathrm{T} 2$ = ethephon; $\mathrm{T} 3$ = 1-MCP; $\mathrm{T} 4$ = ácido salicílico; $\mathrm{T} 5$ = 1-MCP + ácido salicílico.

\section{Coloração da casca (Ângulo de cor - ${ }^{\circ} h$ )}

De modo geral, observou que os frutos ao longo do armazenamento perderam sua coloração verde da casca (Tabela 11).

Observou que os frutos que sofreram somente a aplicação de 1MCP mantiveram a coloração da casca verde, como verificado por Kluge et al. (2003), porém a coloração foi mantida somente até 15 dias de armazenamento, pois a partira daí os frutos apresentaram alto índice de injúria pelo frio, o que mascarou a preservação da cor. 
Tabela 11. Coloração da casca (ângulo de cor) de lima ácida 'Tahiti' armazenada a $1{ }^{\circ} \mathrm{C}$ em função dos tratamentos ${ }^{1}$

\begin{tabular}{|c|c|c|c|c|c|}
\hline \multirow[b]{2}{*}{ Tratamentos $^{2}$} & \multicolumn{5}{|c|}{ Tempo de armazenamento } \\
\hline & 0 dias & 15 dias & 30 dias & 45 dias & Médias \\
\hline \multicolumn{6}{|c|}{ 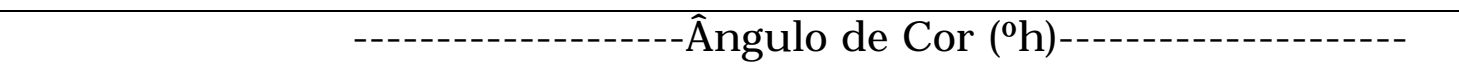 } \\
\hline $\mathrm{T} 1$ & 122,3 a $A$ & 118,3 a $\mathrm{AB}$ & 113,8 b B & 111,9 a B & $116,6 \mathrm{ab}$ \\
\hline $\mathrm{T} 2$ & 122,3 a $A$ & $119,0 \mathrm{a} A B$ & $115,8 \mathrm{ab} B$ & $106,6 \mathrm{ab} C$ & $115,9 \mathrm{ab}$ \\
\hline T3 & 122,3 a $\mathrm{A}$ & 120,9 a $\mathrm{A}$ & 118,0 a $\mathrm{A}$ & 110,4 a B & $117,9 \mathrm{a}$ \\
\hline $\mathrm{T} 4$ & 122,3 a $A$ & 119,8 a $\mathrm{AB}$ & $115,8 \mathrm{ab} B$ & $101,4 \mathrm{~b} \mathrm{C}$ & $114,9 \mathrm{~b}$ \\
\hline T5 & 122,3 a $\mathrm{A}$ & 118,6 a $\mathrm{AB}$ & $115,8 \mathrm{ab} B$ & $104,8 \mathrm{ab} \mathrm{C}$ & $115,1 \mathrm{~b}$ \\
\hline Médias & $122,3 \mathrm{~A}$ & $119,67 \mathrm{~B}$ & $115,95 \mathrm{C}$ & $108,13 \mathrm{D}$ & \\
\hline
\end{tabular}

${ }^{1}$ Médias seguidas de mesma letra minúscula na coluna e maiúscula na linha não diferem entre si pelo teste de Tukey (5\%).

2 T1 = controle; T2 = ethephon; T3 = 1-MCP; T4 = ácido salicílico; T5 = 1-MCP + ácido salicílico.

\section{Teor de sólidos solúveis totais (SST)}

O teor SST teve pouca variação durante o experimento, tendo variado de 7,67 a $8,45^{\circ}$ Brix (Tabela 12).

De modo geral, observou-se que ao longo do armazenamento houve um decréscimo do teor de sólidos solúveis. Os sólidos solúveis totais são compostos solúveis em água e importantes na determinação da qualidade da fruta. O teor de SST nos dá o indicativo da quantidade de açúcares existentes da fruta, além de compostos como ácidos, vitaminas e aminoácidos (Kluge et al., 2002). Esses compostos são substratos da respiração, que é o principal processo metabólico dos frutos, após a colheita, que consiste na conversão desses compostos em energia química para manterem sua atividade metabólica, uma vez que não existe mais relação fonte-dreno com a planta. 
Embora a lima ácida 'Tahiti' seja um fruto não climatérico e possua baixa taxa respiratória, é provável que parte dos sólidos solúveis tenha sido consumida na atividade respiratória.

Tabela 12. Teor de sólidos solúveis de lima ácida 'Tahiti' armazenada a $1^{\circ} \mathrm{C}$ em função dos tratamentos ${ }^{1}$

\begin{tabular}{|c|c|c|c|c|c|}
\hline \multirow[b]{2}{*}{ Tratamentos $^{2}$} & \multicolumn{5}{|c|}{ Tempo de armazenamento } \\
\hline & 0 dias & 15 dias & 30 dias & 45 dias & Médias \\
\hline & \multicolumn{5}{|c|}{ 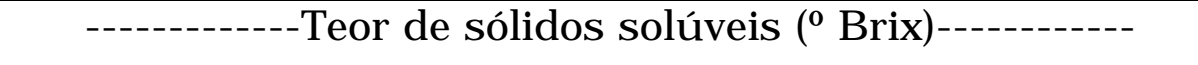 } \\
\hline $\mathrm{T} 1$ & 8,32 a $A$ & 8,15 a $\mathrm{A}$ & 8,40 ab A & 7,95 a $\mathrm{A}$ & $8,21 \mathrm{a}$ \\
\hline $\mathrm{T} 2$ & 8,32 a $A$ & 8,37 a $\mathrm{A}$ & 8,42 a $\mathrm{A}$ & 7,67 a $\mathrm{B}$ & $8,20 \mathrm{a}$ \\
\hline T3 & 8,32 a $\mathrm{AB}$ & 8,07 a $\mathrm{AB}$ & 8,45 a $\mathrm{A}$ & 7,85 a B & $8,17 \mathrm{a}$ \\
\hline $\mathrm{T} 4$ & 8,32 a $A$ & 8,15 a $\mathrm{AB}$ & $7,90 \mathrm{~b} \mathrm{AB}$ & 7,70 a $B$ & $8,02 \mathrm{a}$ \\
\hline T5 & 8,32 a $\mathrm{A}$ & 8,10 a $A$ & 8,22 ab A & 8,05 a $A$ & $8,17 \mathrm{a}$ \\
\hline Médias & $8,32 \mathrm{~A}$ & $8,17 \mathrm{~A}$ & $8,28 \mathrm{~A}$ & $7,84 \mathrm{~B}$ & \\
\hline
\end{tabular}

${ }^{1}$ Médias seguidas de mesma letra minúscula na coluna e maiúscula na linha não diferem entre si pelo teste de Tukey (5\%).

$2 \mathrm{~T} 1$ = controle; $\mathrm{T} 2$ = ethephon; $\mathrm{T} 3$ = 1-MCP; $\mathrm{T} 4$ = ácido salicílico; $\mathrm{T} 5$ = 1-MCP + ácido salicílico.

\section{Acidez titulável (AT)}

As diferenças nos teores da acidez ao longo do armazenamento foram pequenas e ambos tratamentos mostraram um decréscimo no teor de acidez durante o armazenamento (Tabela 13). Essa diminuição nos teores de acidez durante o armazenamento é um processo que pode ocorrer, considerando que os ácidos podem também servir de substratos para a respiração (Awad, 1993). Segundo Ballod (1990), ocorre a oxidação dos ácidos para a produção de energia no ciclo de Krebs. 
Não houve diferença entre os tratamentos ao longo do armazenamento, mostrando que aplicação de ethephon, 1-MCP e ácido salicílico não interferem no teor de acidez em lima ácida 'Tahiti'.

Lederman et al. (1997) e Autio \& Bramlage (1986) comentam que um dos danos provocados pelo frio em frutas é o aumento desordenado na produção de etileno e respiração. Isso pode ter provocado, no presente trabalho, a utilização de quantidade de ácidos no processo respiratório dos frutos submetidos aos tratamentos que apresentaram injúria pelo frio.

Tabela 13. Acidez titulável de lima ácida 'Tahiti' armazenada a $1^{\circ} \mathrm{C}$ em função dos tratamentos ${ }^{1}$

\begin{tabular}{lccccc}
\hline & \multicolumn{5}{c}{ Tempo de armazenamento } \\
Tratamentos $^{2}$ & 0 dias & 15 dias & 30 dias & 45 dias & Médias \\
\hline \multirow{2}{*}{ T1 } & 6,00 a A & 6,20 a AB & 5,61 a BC & 5,27 a C & 5,77 a \\
T2 & 6,00 a A & 5,84 a A & 5,64 a A & 5,12 a B & 5,65 a \\
T3 & 6,00 a A & 6,08 a A & 5,82 a A & 5,33 a B & 5,81 a \\
T4 & 6,00 a A & 5,85 a A & 5,56 a AB & 5,11 a B & 5,63 a \\
T5 & 6,00 a A & 5,90 a AB & 5,60 a AB & 5,44 a B & 5,74 a \\
Médias & $6,00 \mathrm{~A}$ & $5,98 \mathrm{~A}$ & $5,65 \mathrm{~B}$ & $5,26 \mathrm{C}$ & \\
\hline
\end{tabular}

${ }^{1}$ Médias seguidas de mesma letra minúscula na coluna e maiúscula na linha não diferem entre si pelo teste de Tukey (5\%).

$2 \mathrm{~T} 1$ = controle; $\mathrm{T} 2$ = ethephon; $\mathrm{T} 3$ = 1-MCP; $\mathrm{T} 4$ = ácido salicílico; $\mathrm{T} 5$ = 1-MCP + ácido salicílico. 


\section{"Ratio"}

O "ratio" apresentou pouca variação durante o experimento, tendo os valores oscilado entre 1,31 e 1,51, sem efeito significativo entre os tratamentos (Tabela 14).

Tabela 14. "Ratio" de lima ácida 'Tahiti' armazenada a $1^{\circ} \mathrm{C}$ em função dos tratamentos ${ }^{1}$

\begin{tabular}{lccccc}
\hline & \multicolumn{5}{c}{ Tempo de armazenamento } \\
Tratamentos & 0 dias & 15 dias & 30 dias & 45 dias & Médias \\
\hline T1 & 1,39 a AB & 1,31 a B & 1,50 a A & 1,51 a A & 1,43 a \\
T2 & 1,39 a A & 1,44 a A & 1,50 a A & 1,50 a A & 1,45 a \\
T3 & 1,39 a A & 1,33 a A & 1,45 a A & 1,47 a A & 1,41 a \\
T4 & 1,39 a A & 1,39 a A & 1,42 a A & 1,51 a A & 1,43 a \\
T5 & 1,39 a A & 1,38 a A & 1,47 a A & 1,48 a A & 1,43 a \\
Médias & $1,39 \mathrm{~B}$ & $1,37 \mathrm{~B}$ & $1,47 \mathrm{~A}$ & 1,49 a A & \\
\hline
\end{tabular}

1 Médias seguidas de mesma letra minúscula na coluna e maiúscula na linha não diferem entre si pelo teste de Tukey (5\%).

2 T1 = controle; $\mathrm{T} 2$ = ethephon; $\mathrm{T} 3$ = 1-MCP; $\mathrm{T} 4$ = ácido salicílico; $\mathrm{T} 5$ = 1-MCP + ácido salicílico.

\section{Índice tecnológico (I.T.)}

O índice tecnológico teve efeito significativo entre o tempo de saída dos frutos da refrigeração, bem como a interação entre estes fatores e teve efeito significativo entre os tratamentos aos 45 dias de armazenamento (Tabela 15).

Observa-se, de modo geral, um decréscimo no I.T. ao longo do armazenamento em todos os tratamentos. O I.T. é a determinação que 
leva em consideração a porcentagem de suco, valores estes que foram maiores nos frutos que foram submetidos a aplicação de 1-MCP + ácido salicílico.

Tabela 15. Índice tecnológico de lima ácida ‘Tahiti’ armazenada a $1^{\circ} \mathrm{C} \mathrm{em}$ função dos tratamentos ${ }^{1}$

\begin{tabular}{|c|c|c|c|c|c|}
\hline \multirow[b]{2}{*}{ Tratamentos $^{2}$} & \multicolumn{5}{|c|}{ Tempo de armazenamento } \\
\hline & 0 dias & 15 dias & 30 dias & 45 dias & Médias \\
\hline & \multicolumn{5}{|c|}{--1 } \\
\hline $\mathrm{T} 1$ & 3,95 a $\mathrm{A}$ & 3,60 a $\mathrm{A}$ & 3,58 a $A$ & $2,86 \mathrm{ab} \mathrm{B}$ & $3,50 \mathrm{ab}$ \\
\hline $\mathrm{T} 2$ & 3,95 a $\mathrm{A}$ & 3,37 a $B$ & 3,87 a $A$ & $2,88 \mathrm{ab} \mathrm{B}$ & $3,51 \mathrm{ab}$ \\
\hline T3 & 3,95 a $\mathrm{A}$ & 3,53 a $\mathrm{A}$ & 3,64 a $A$ & $2,86 \mathrm{ab} B$ & $3,50 \mathrm{ab}$ \\
\hline $\mathrm{T} 4$ & 3,95 a $\mathrm{A}$ & 3,56 a B & 3,53 a $\mathrm{AB}$ & $2,52 \mathrm{~b} \mathrm{~B}$ & $3,39 \mathrm{~b}$ \\
\hline T5 & 3,95 a $\mathrm{A}$ & 3,78 a $A$ & 3,79 a $A$ & 3,05 a A & $3,65 \mathrm{a}$ \\
\hline Médias & $3,95 \mathrm{~A}$ & $3,57 \mathrm{~B}$ & $3,68 \mathrm{~B}$ & $2,84 \mathrm{C}$ & \\
\hline
\end{tabular}

${ }^{1}$ Médias seguidas de mesma letra minúscula na coluna e maiúscula na linha não diferem entre si pelo teste de Tukey (5\%).

$2 \mathrm{~T} 1$ = controle; $\mathrm{T} 2$ = ethephon; $\mathrm{T} 3$ = 1-MCP; $\mathrm{T} 4$ = ácido salicílico; $\mathrm{T} 5$ = 1-MCP + ácido salicílico.

\section{Atividade de enzimas antioxidantes}

As atividades das enzimas forma determinadas logo após a retirada dos frutos do armazenamento refrigerado a $1^{\circ} \mathrm{C}$, aos 15 e 30 dias. Aos 45 dias de armazenamento os frutos não foram avaliados, pois não estavam em condições comercializáveis e os danos pelo frio (manchas na casca) ultrapassavam 50\% da área total da casca (nota $4=$ muito severa). Foram avaliadas as atividades de catalase (CAT), superóxido dismutase (SOD), ascorbato peroxidase (APX) e glutationa redutase (GR). 
Observou-se que houve poucas variações das atividades das enzimas antioxidativas. Esse fato não era esperado, pois o estresse pelo frio é considerado um estresse oxidativo (Rao et al., 1996), onde há produção de espécies ativas de oxigênio (superóxido e peróxido de hidrogênio). Nas plantas existem um complexo sistema antioxidante que protegem contra os altos níveis das espécies ativas de oxigênio, o qual incluem três classes: lipossolúveis (antioxidantes associados a membrana - $\alpha$-tocopherol, e $\beta$ caroteno), hidrossolúveis (glutationa e ascorbato), e por fim o sistema enzimático (por exemplo, Superóxido Dismutase, Catalase e Peroxidase).

A CAT atua como regulador dos niveis de $\mathrm{H}_{2} \mathrm{O}_{2}$, os quais são decompostos em $\mathrm{H}_{2} \mathrm{O}$ e $\mathrm{O}_{2}$ (Scandalios, 1990), e esse $\mathrm{H}_{2} \mathrm{O}_{2}$ é totalmente tóxico a célula, sendo uns dos compostos que leva à morte celular, que no caso do estresse pelo frio causa manchas deprimidas necróticas na casca de lima ácida 'Tahiti'. A atividade da catalase (Figura 29) apresentou poucas variações durante o período de armazenamento e entre os tratamentos, onde pode ser observado que os frutos que foram submetidos aos tratamentos com ethephon, 1-MCP e ácido salicílico não diferiram entre si, mas apresentaram diferença entre os frutos do controle, os quais apresentaram maior atividade de catalase, associado com a incidência de injúria pelo frio, ou seja, maior a atividade de catalase, menor a incidência de dano. Segundo Ben-Amor (1999), a aplicação de etileno reduziu a atividade de CAT e SOD, bem como em folhas de espinafre que foram submetidos à aplicação de etileno, obtiveram menor atividades de CAT, SOD e GR (Hodges \& Forney, 2000). 


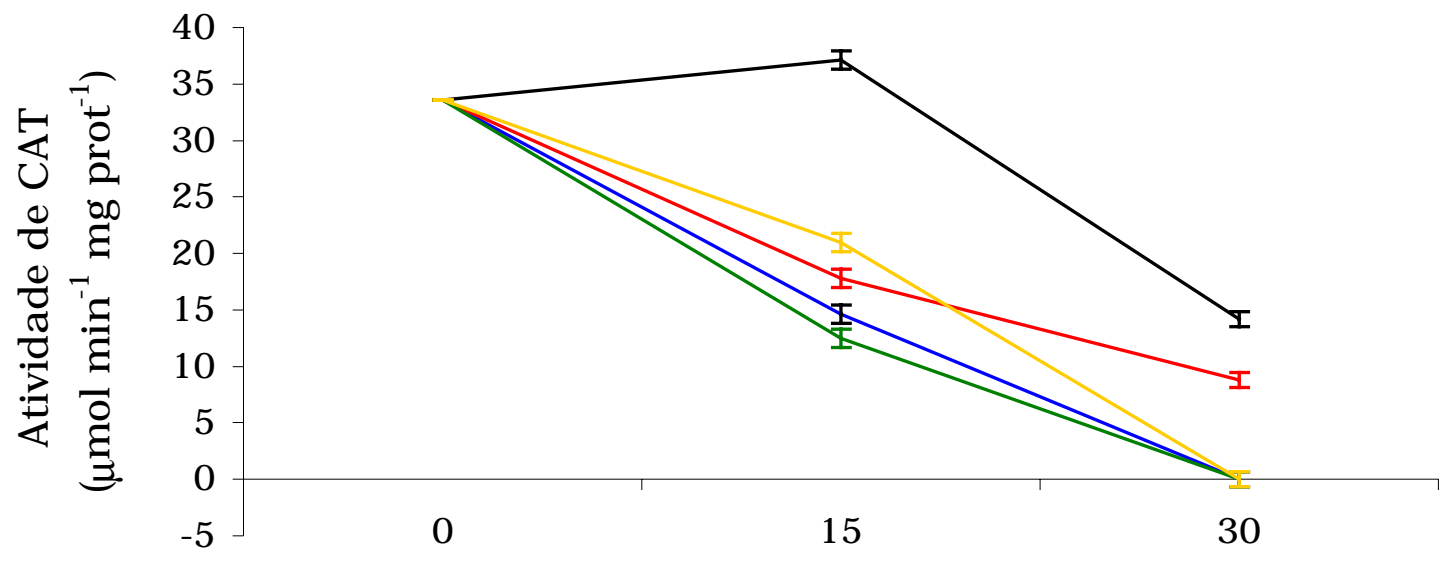

Dias de armazenamento

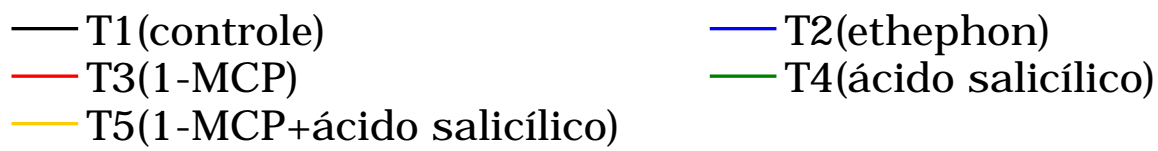

Figura 29 - Atividade específica de Catalase (CAT) em lima ácida 'Tahiti' armazenada a $1^{\circ} \mathrm{C}$. As barras verticais representam o desvio padrão da média

Os resultados de PAGE - gel não desnaturante (Figura 30 e 31) demonstraram variação na atividade total das isoformas de SOD, relacionadas aos tratamentos e tempo de armazenamento.

As SODs são enzimas que contém metais ligados a sua estrutura e catalisam a dismutação do radical superóxido em $\mathrm{O}_{2}$ e $\mathrm{H}_{2} \mathrm{O}_{2}$ (Mattson, 1998), regulando assim, os níveis de superóxido e peróxido de hidrogênio que são substratos da reação que origina os radicais de hidroxila, representando por isso, o papel central no mecanismo de defesa antioxidante (Alscher et al., 1998; 2002).

Em plantas existem três formas desta enzima, as quais são classificadas segundo o íon metálico em seu sítio ativo: formas cobre/zinco (Cu/Zn-SOD), manganês (Mn-SOD) e ferro (Fe-SOD) (Bowler et al., 1994; Chen \& Liu, 1996). 
A atividade de SOD, bem como a expressão dos genes que codificam suas isoformas tem mostrado sofrer alterações sob diversas condições de estresse (Willekens et al., 1995).

Observa-se que todos tratamentos apresentaram atividade de SOD, onde se notou que o tratamento em que os frutos foram submetidos à aplicação de ethephon apresentaram maior atividade de SOD, determinada pela maior intensificação da revelação do gel de poliacrilamida, em oposição aos resultados de Hodges \& Forney (2000) e Bem-Amor et al. (1999).

Ao longo do armazenamento, parece não apresentar diferença na atividade de SOD.

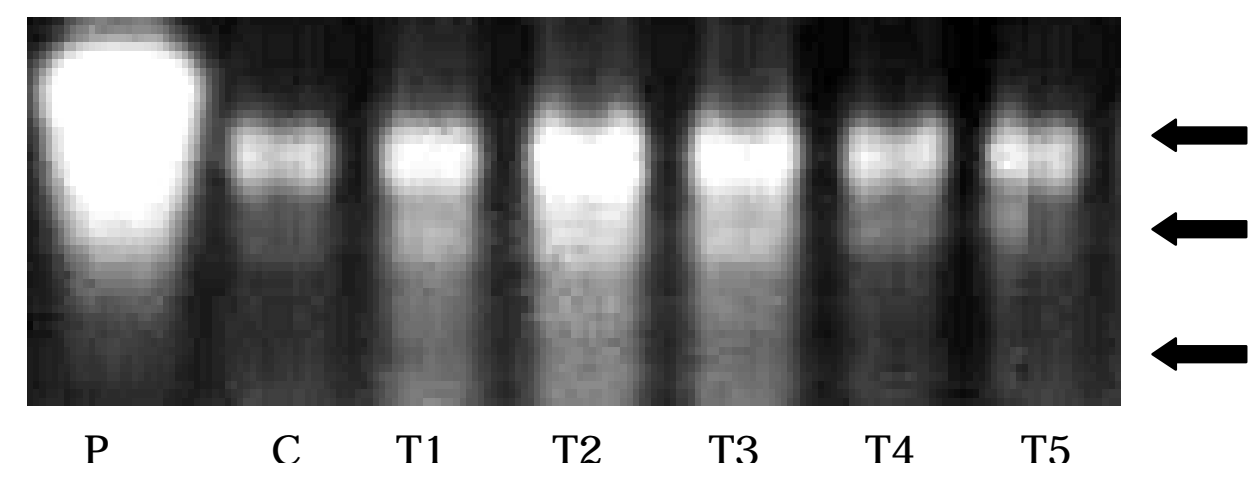

Figura 30 - Atividade de SOD de lima ácida 'Tahiti' armazenada a $1^{\circ} \mathrm{C}$, determinada em PAGE não desnaturante; (P) padrão de SOD de fígado bovino, (C) caracterização, (T1) controle, (T2) aplicação de ethephon, (T3) aplicação de 1-MCP, (T4) aplicação de ácido salicílico, (T5) aplicação de 1-MCP + ácido salicílico, aos 15 dias de armazenamento refrigerado. As setas representam as isoformas de SOD 


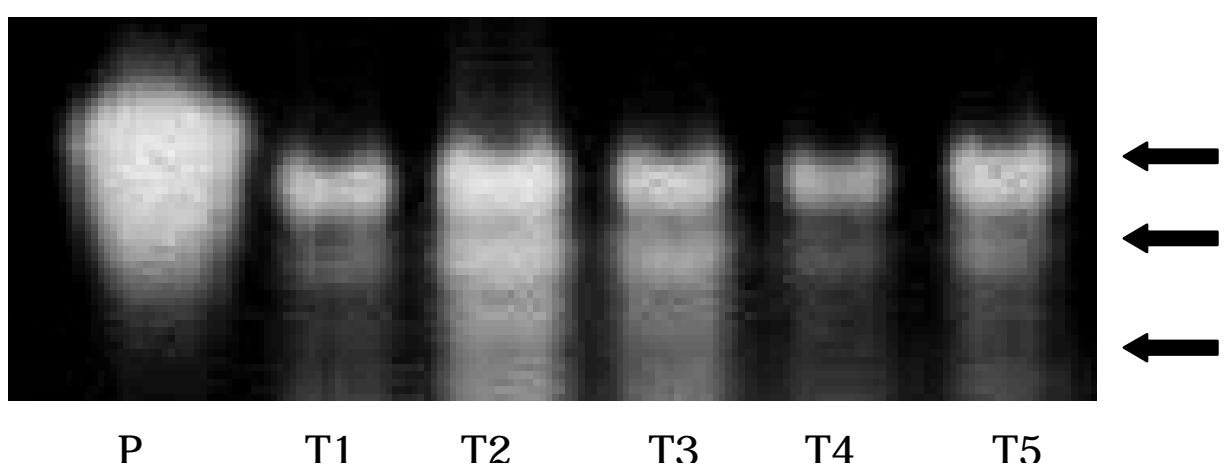

Figura 31 - Atividade de SOD de lima ácida 'Tahiti' armazenada a $1^{\circ} \mathrm{C}$, determinada em PAGE não desnaturante; (P) padrão de SOD de fígado bovino, (T1) controle, (T2) aplicação de ethephon, (T3) aplicação de 1-MCP, (T4) aplicação de ácido salicílico, (T5) aplicação de 1-MCP + ácido salicílico, aos 30 dias de armazenamento refrigerado. As setas representam as isoformas de SOD

A glutationa representa muitas funções no metabolismo de plantas. Está envolvida na desintoxicação de metais e tem papel na ativação gênica e na proteção de estresse oxidativo, como o causado pelo frio (Noctor \& Foyer, 1998; Schutzendubel et al., 2001). Como antioxidantes, a glutationa, o ascorbato e as enzimas como SOD, CAT e APX controlam as concentrações celulares de superóxido e peróxido de hidrogênio. A reciclagem de ascorbato e glutationa é realizada pela monodehidroascorbato, dehidroascorbato redutase e glutationa redutase (GR) (Schutzendubel et al., 2001). Observa-se que houve a atividade da GR, porém não diferiu significativamente entre os tratamentos (Figura 32), ao longo do armazenamento.

A glutationa reage quimicamente com os radicais livres, enquanto as enzimas catalisam reações ligando a glutationa reduzida a desintoxicação de $\mathrm{H}_{2} \mathrm{O}_{2}$ no ciclo ascorbato-glutationa. Como foi 
verificado, é necessário que tenha atividade de GR para manter os níveis celulares de glutationa, tanto reduzida como oxidada (Noctor et al., 2002).

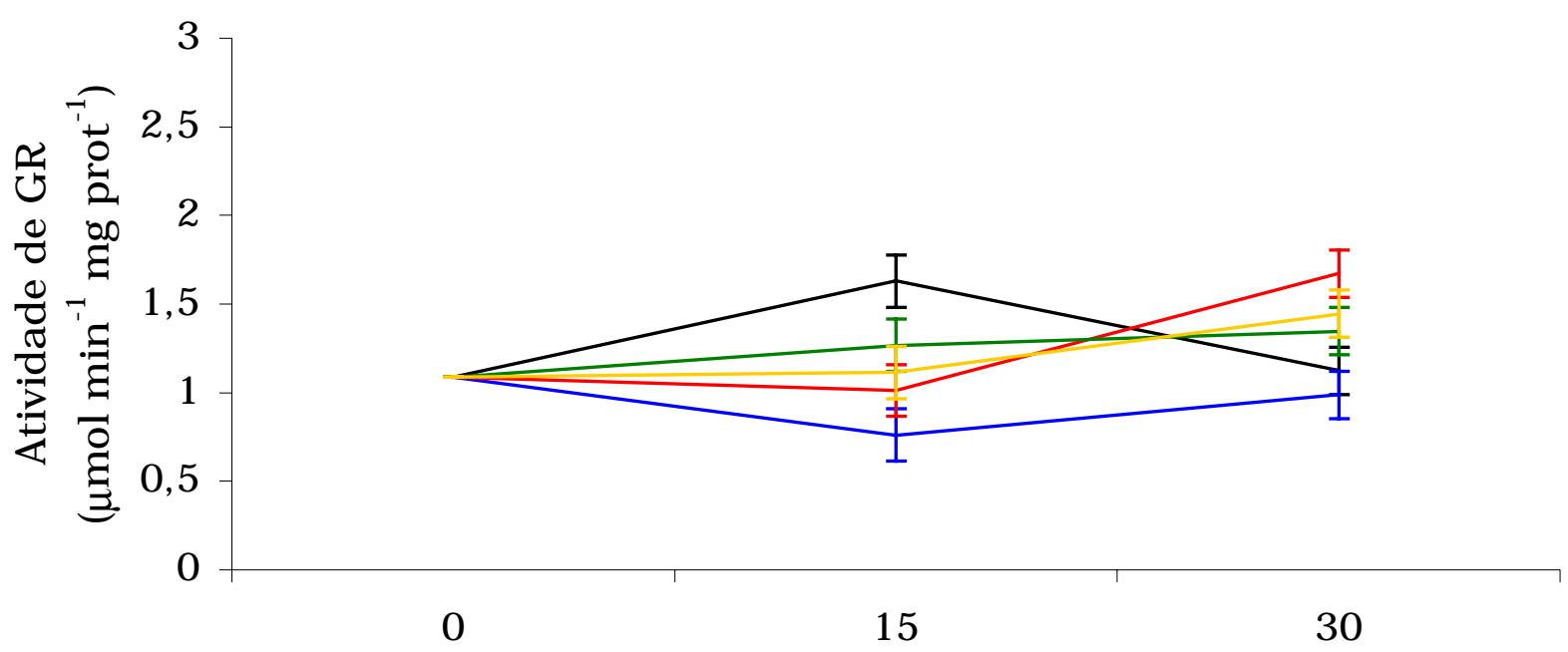

Dias de armazenamento

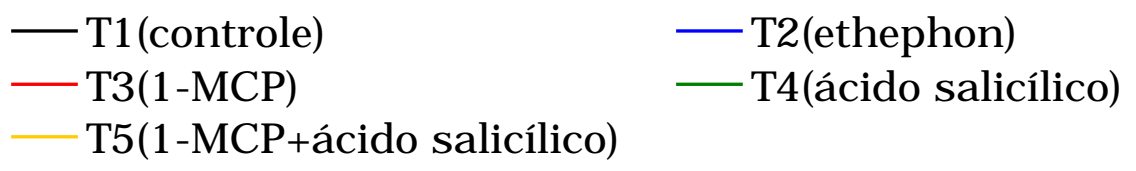

Figura 32 - Atividade específica de Glutationa Redutase (GR) em lima ácida 'Tahiti' armazenada a $1^{\circ} \mathrm{C}$. As barras verticais representam o desvio padrão da média

As peroxidases catalisam a oxidação do substrato utilizando o poder oxidante de $\mathrm{H}_{2} \mathrm{O}_{2}$, ou peróxidos orgânicos. As isoenzimas diferem em sua capacidade por distintos substratos. De acordo com o observado para uma das peroxidases analisada, a ascorbato peroxidase (Figura 33), os resultados não foram evidentes, pois não apresentou nenhuma correlação com o etileno, tanto endógeno quanto exógeno. 


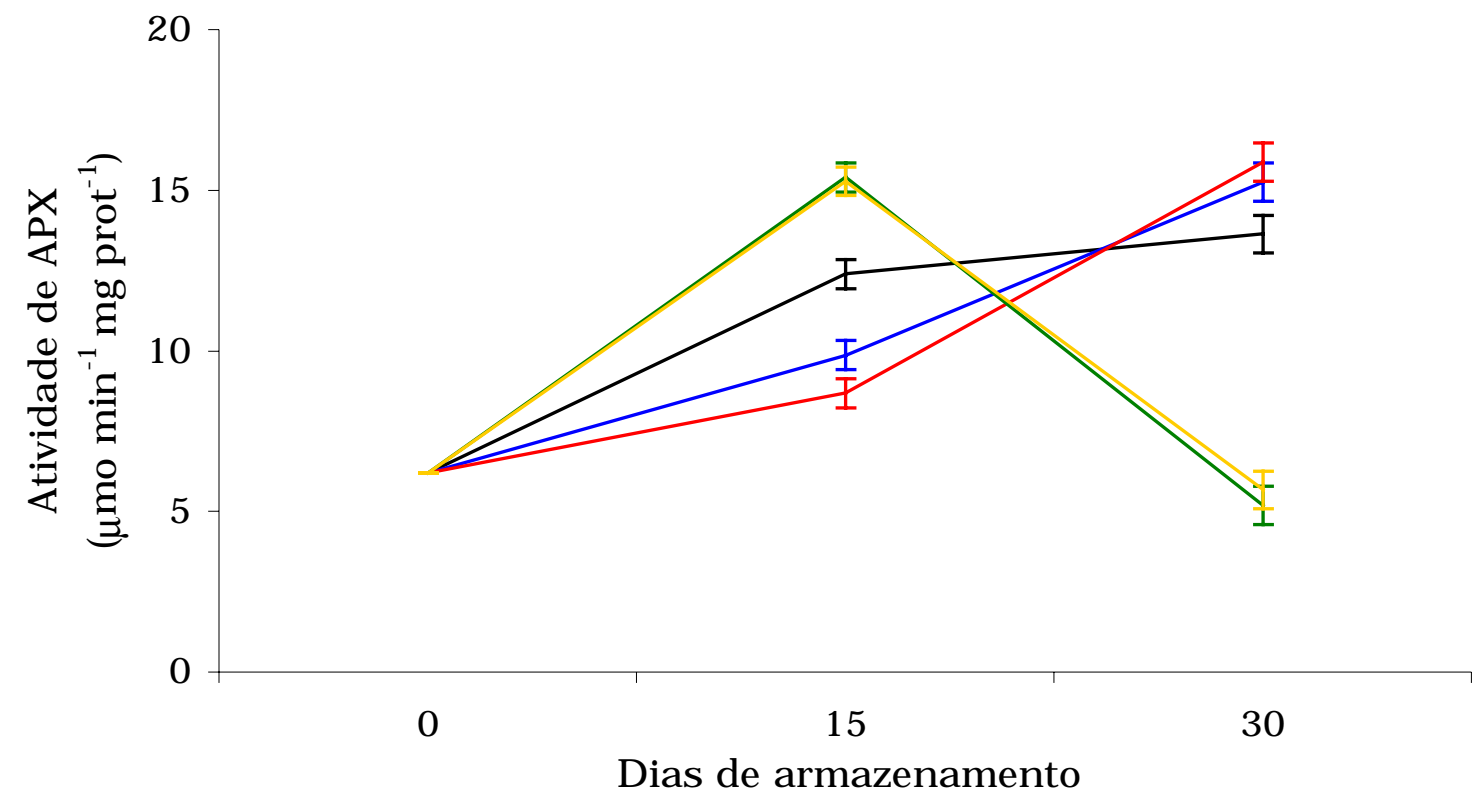

— T1(controle)
- T3(1-MCP)
T5(1-MCP+ácido salicílico)

- T2(ethephon)

— T4(ácido salicílico)

Figura 33 - Atividade específica de Ascorbato Peroxidase (APX) em lima ácida 'Tahiti' armazenada a $1^{\circ} \mathrm{C}$. As barras verticais representam o desvio padrão da média

\section{Poliaminas}

Os resultados das análises de poliaminas estão apresentados abaixo nas Figuras 34, 35 e 36, respectivamente, putrescina (Put), espermidina (Spd) e espermina (Spm). 


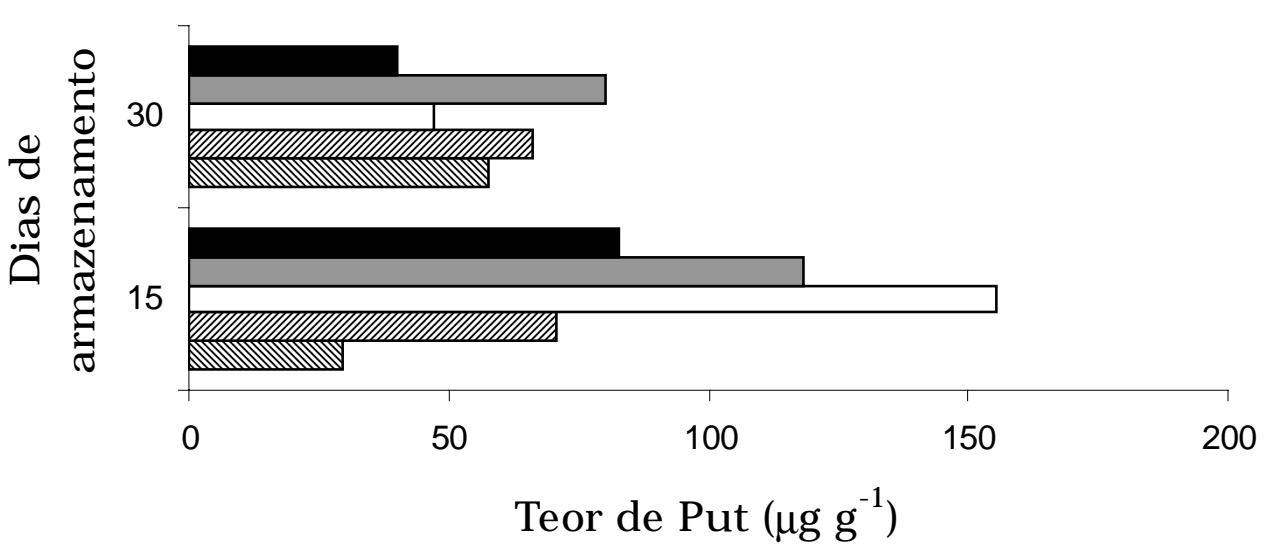
$\mathbb{\mathbb { T } 1}$ - Controle
圆 $\mathrm{T} 2$ - Ethephon
$\square \mathrm{T} 3$ - 1-MCP
$\square T 4$ - Ác. Salicílico
口T5 - 1-MCP e Ác. Salicílico

Figura 34 - Teor de Putrescina (Put) em casca de lima ácida 'Tahiti' armazenada a $1^{\circ} \mathrm{C}$ em função de diferentes tratamentos

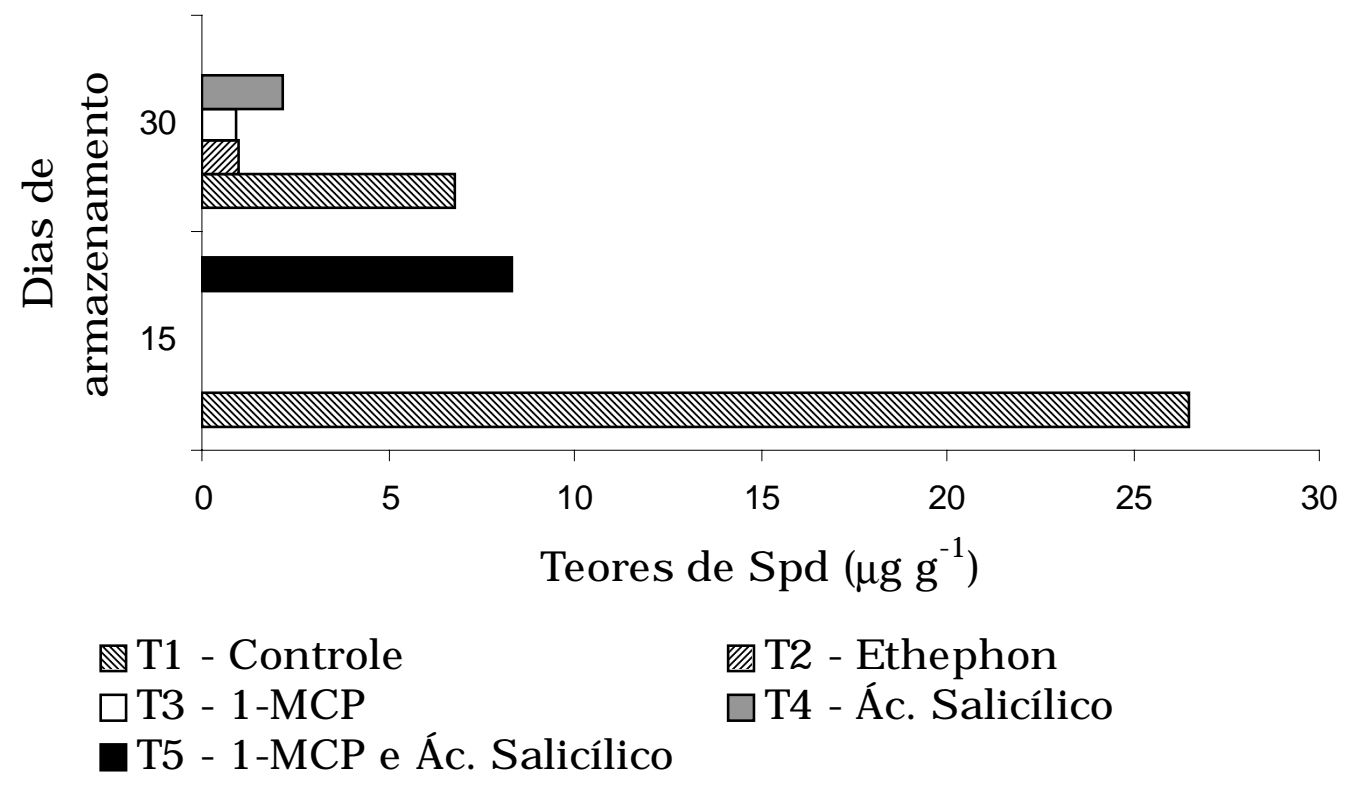

Figura 35 - Teor de Espermidina (Spd) em casca de lima ácida 'Tahiti' armazenada a $1^{\circ} \mathrm{C}$ em função de diferentes tratamentos 


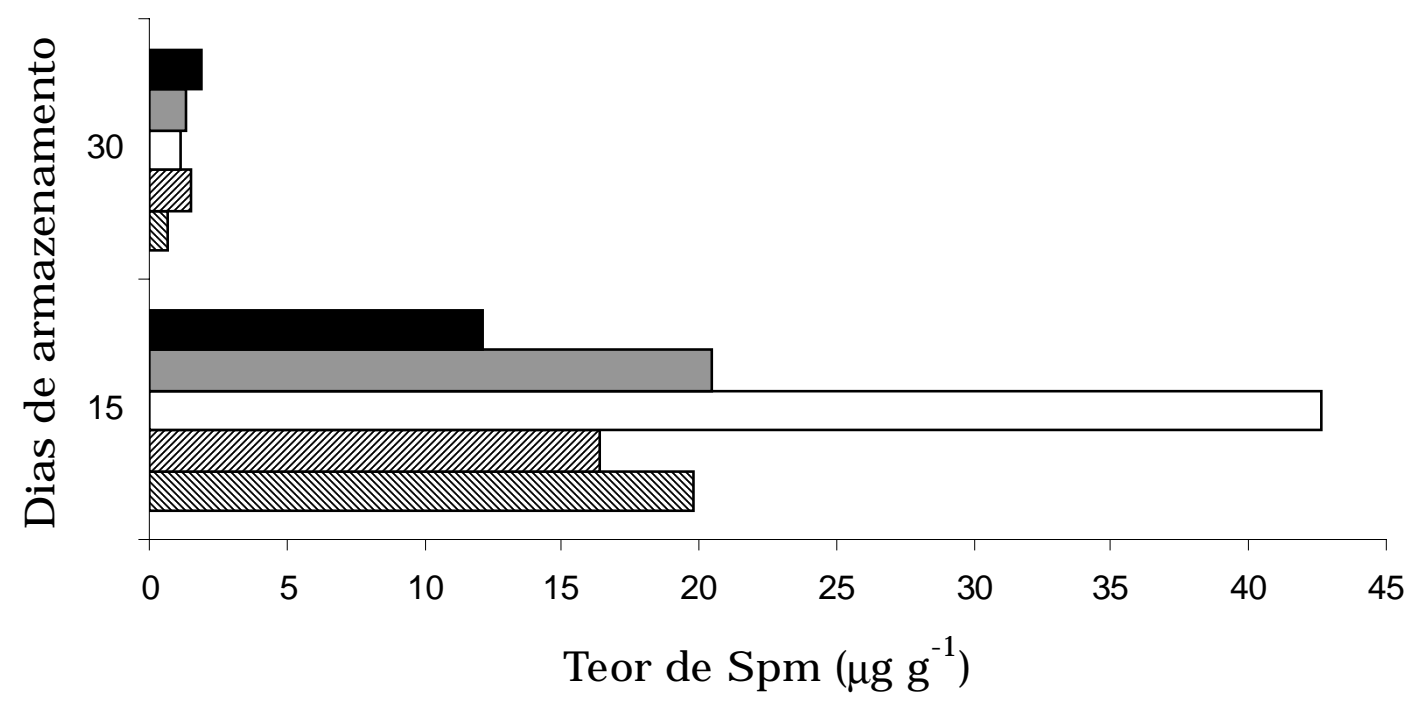

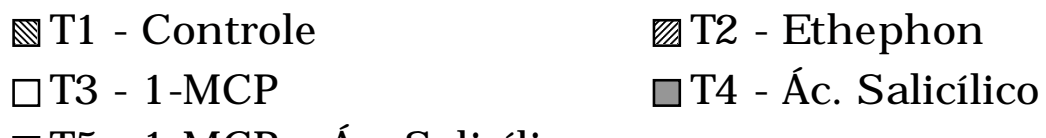

Figura 36 - Teor de Espermina (Spm) em casca de lima ácida 'Tahiti' armazenada a $1^{\circ} \mathrm{C}$ em função de diferentes tratamentos

No presente trabalho não foi possivel relacionar os teores de poliaminas com os tratamentos aplicados aos frutos de lima ácida 'Tahiti' armazenados à baixa temperatura. Resultados descritos por diversos autores, não indicaram se a alteração nos teores de putrescina é um mecanismo de proteção ou se esta amina poderia ser uma resposta ao estresse, entretanto vários trabalhos na literatura afirmaram que as poliaminas agem como protetores das plantas quando submetidas a estresse por baixa temperatura (Galston \& Kaur-Sawhney, 1995; Bouchereau et al., 1999). Em várias espécies, o aumento de poliaminas estaria correlacionado com a redução das injúrias causadas por este tipo de estresse (Wang \& Ji, 1989; Kramer \& Wang, 1989, 1989). Estes resultados são consistentes com a sugestão que as poliaminas 
preservam a integridade da membrana, resultando num aumento da viabilidade da célula durante o estresse causado pela baixa temperatura, porém no trabalho não se conseguiu correlacionar o teor de poliaminas com o etileno, pois todos os frutos apresentaram injúria pelo frio, independe dos tratamentos.

\subsection{Conclusão}

Em frutos de lima ácida 'Tahiti', não foi possível verificar o envolvimento do etileno na resistência a baixa temperatura, pois não teve diferença na incidência de injúria pelo frio entre os tratamentos. 


\section{CONSIDERAÇÃO FINAL}

Muitos estudos ainda são necessários para se conhecer o mecanismo de resistência dos frutos à baixa temperatura.

Com o presente projeto conseguiu-se relacionar o efeito do aquecimento intermitente com a atividade das enzimas antioxidantes, aumentando a resistência dos frutos, porém não foi possível correlacionar com os teores de poliaminas, sendo necessários novos testes para definir uma metodologia mais adequada, a fim de buscar respostas bioquímicas mais exatas.

Nesse trabalho, também não foi possível correlacionar o envolvimento do etileno com a resistência dos frutos de lima ácida 'Tahiti' à baixa temperatura, sendo necessários, por exemplo, estudos relacionados a dosagens dos produtos utilizados. Diante de tantos desafios, o monitoramento diário da produção de etileno e outros parâmetros ligados a esse hormônio deveriam ser melhor pesquisados. 


\section{REFERÊNCIAS BIBLIOGRÁFICAS}

ABDI, N.; McGLASSON, W.B.; HOLFORD, P. et al. Responses of climateric and suppressed-climateric plums to treatment with propylene and 1-metylcyclopropene. Posthaverst Biology and Technology, v.14, p.29-39, 1998.

ABELES, F.B; MORGAN, P.W.; SALTVEIT, M.E. Ethylene in plant biology. 2 ed. San Diego: Academic Press, 1997. 414p.

ALLEN, R.D. Dissection of oxidative stress tolerance using transgenic plants. Plant Physiology, v.77, n.4, p.1049-1054, 1995.

ALSCHER, R.G.; DONAHUE, J.L.; CRAMER, L. Reactive oxygen species and antioxidants relationship in green cells. Physiologia Plantarum, v.100, p.224-233, 1998.

ALSCHER, R.G.; ERTURK, N.; HEATH, L.S. Role of superoxide dismutase (SODs) in controlling oxidative stress in plants. Journal of Experimental Botany, v.53, n.372, p.1331-1341, 2002. 
ARTÉS, F. Innovaciones en los tratamientos físicos para preservar la calidad de los productos hortifrutícolass en la postrecolecion. I. Pretratamientos térmicos. Revista Española de Ciência Y Tecnologia de Alimentos, v.35, n.1, p.45-64, 1995.

AUTIO, W.R.; BRAMLAGE, W.J. Chilling sensitivity of tomato fruit in relation to ripening and senescence. Journal of the American Society for Horticultural Science, v.111, n.2, p.201-204, 1986.

AWAD, M. Fisiologia pós-colheita de frutos. São Paulo: Nobel, 1993. $114 \mathrm{p}$.

AZEVEDO, R.A.; ALAS, R.M.; SMITH, R.J. et al. Response of antioxidant enzymes to transfer from elevated carbon dioxide to air and ozone fumigation, in the leaves and roots of wild-tipe and catalase-deficient mutant of barley. Physiologia Plantarum, v.104, n.2, p.280-292, 1998.

BALDWIN, E.A. Citrus fruit. In: SEYMOR, G. B.; TAYLOR, J.E.; TUCKER, G.A. (Ed.). Biochemistry of fruit ripening. London: Chapman \& Hall, 1994. p. 255-271.

BARRACHINA, A.C.; GARRIDO, D.V.; ROMERO, D.M. et al. Polyamines: Biosyntheses, metabolism, and their role in ripening and posthaverst handling if fruit. Journal Food Science and Technology International, v.6, n.2, p.85-95, 2000. 
BARROS, S.A.; RODRIGUES, J.D.; RODRIGUES, S.D. et al. Efeito do ácido giberélico e do uniconazole na fisiologia pós-colheita do limão 'Tahiti' (Citrus latifolia Tanaka). Revista Brasileira de Fruticultura, v. 13, n.3, p.223-226, 1991.

BECANA, M.; MORAN, J.F.; ITURBE-ORMAEXTE, I. Iron-dependent oxygen free radicalgeneration in plants subjected toenvironmental stressÇ Toxicity and antioxidant protection. Plant and Soil, v.201, p.137-147, 1998.

BECK, A.; LENDZIAN, K.; OVEN, M. et al. Phytochelatin synthase catalyzes key step in turnover of glutathione conjugates. Phytochemistry, v.62, p.423-431, 2003.

BEN-AMOR, M.; FLORES, B.; LATCHE, A. et al. Inhibition of ethylene biosynthesis by antisense ACC oxidase RNA prevents chilling injury in Charentais cantaloupe melons. Plant Cell and Environment, v.22, n.12, p.1579-1586, 1999.

BEN-YEHOSHUA, S.; SHAPIRO, B.; MORAN, R. Individual seal-packing enables the use of curing at high temperatures to reduce decay and heal injury of citrus fruit. Hortscience, v.22, p.777-783, 1987.

BLANKENSHIP, S.M.; DOLE, J.M. 1-Methylcyclopropene: a review. Postharvest Biology and Technology, v.28, p.1-25, 2003.

BOUCHEREAU, A.; AZIZ, A.; LARHER, F. et al. Polyamines and environmental challenges: recent development. Plant Physiology, v.140, p.103-125, 1999. 
BOWLER, C.; VAN CAMP, W.; VAN MONTAGU, M. et al. Superoxidedismutase in plants. Critical Reviews in Plant Science, v.13, n.3, p.199-218, 1994.

BROWN, G.E.; LEE, H.S. Interactions of ethylene with citrus stem-end not caused by Diplodia natalensis. Phytopathology, v.83, p.1204$1208,1993$.

BUESCHER, R.W. Herd core in sweet potato roots as influenced by cultivar, curing, and ethylene. HortScience, v.12, p.326-327, 1977.

BURG, S.P.; BURG, E.A. Molecular requeriments for the biological activity of ethylene. Plant Physiology, v.42, p.144-152, 1967.

CHAPLIN, G.R.; WILLS, R.B.H.; GRAHEM, D. Induction of chilling injury in stored avocados with exogenous ethylene. HortScience, v.18, p.952-953, 1983.

CHEN, H.Y.; LIU, W.Y. The molecular evolution of superoxide dismutase based on its distribution and structure. Progress in Biochemistry and Biophysics, v.23, n.5, p.408-413, 1996.

CHITARRA, M.I.; CHITARRA, A.B. Pós-colheita de frutos e hortaliças: fisiologia e manuseio. Lavras: ESAL/FAEPE, 1990. 320p.

COELHO, Y.S. Lima ácida 'Tahiti' para exportação: aspectos técnicos de produção. Brasília: MAARA; SDR, 1993. 35 p. (Série Publicações Técnicas Frupex, 1). 
COHEN, E. Commercial use of long-term storage of lemon with intermittent warming. Hortscience, v.23, n.2, p.400, 1988.

CREISSEN, G.P.; BROADBENT, P.; KULAR, B. et al. Manipulation of glutathione-reductase in transgenic plants-implications for responses to environmental-stress. Proceedings of the Royal Society of Edinburgh, Section B - Biological Sciences, v.102, p.167-175, 1994.

DEL RIO, M.A.; CUQUERELLA, J.; RAGONE, M.L. Effects of postharvest curing at high temperature on decay and quality of 'Marsh' grapefruits and navel orange. Proceedings of the International Society of Citriculture, v.3, p.1081-1083, 1992.

DELONG, J.M.; STEFFEN. Lipid peroxidation and $\alpha$-tocopherol content in $\alpha$-tocopherol-supplemented thylakoid membranes during UV-B exposure. Environmental and Experimental Botany, v.39, p.177185, 1998.

DONADIO, L.C. Exigências para a exportação de citros. In: SIMPÓSIO INTERNACIONAL DE FRUTICULTURA; 1. PRODUÇÃO E QUALIDADE DE FRUTOS CÍTRICOS, 1., Botucatu, 1994. Anais. Botucatu: FAPESP, 1999. p.33-45.

DU, Z.; BRAMLAGE, W.J. Peroxidative activity of apple peel in relation to development of poststorage disorders. Journal of Plant Physiology, v.30, p.205-209, 1995. 
ESTANISLAU, M.L.L.; BOTEON, M.; CAMPOS, F.L. et al. Laranjas e sucos: aspectos econômicos. Informe Agropecuário, v.22, p.8-20, mar/abr. 2001.

EVANS, P.T.; MALMBERG, R. Do polyamines have role in plant development? Annual Review of Plant Physiology, v.40, p.235-269, 1989.

FALLIK, E. Prestorage hot water treatments (immersion, rinsing and brushing). Postharvest Biology and Technology, v.32, p.125-134, 2004.

FAN, X.; ARGENTA, L.; MATTHEIS, J.P. Inhibition of ethylene action by 1-methylcyclopropene prolongs storage life of apricots. Postharvest Biology and Technology, v.20, p.135-142, 2000.

FAN, X.; BLANKENSHIP, S.M.; MATTHEIS, J.P. 1-methylcyclopropene inhibits apple ripening. Journal of the American Society for Horticultural Science, v.124, n.6, p.690-695, 1999.

FAUST, M.; WANG, S.Y. Polyamine in horticulture important plants. Horticultural Review, v. 14, p.333-356, 1992.

FENG, X.; APELBAUM, A.; SISLER, E.C. et al. Control of ethylene responses in avocado fruit with 1-methylcyclopropene. Postharvest Biology and Technology, v.20, p.143-150, 2000.

FERNANDA, C. Calidad de los frutos cítricos. Reus: Tecnidex, Técnicas de Desinfección, S.A. y Ediciones de Horticultura, 1996. 154p. 
FIGUEIREDO, J.O.; STUCHI, E.S.; LARANJEIRA, F.F. et al. Portaenxertos para lima ácida 'Tahiti' em duas regiões do Estado de São Paulo. Laranja, v.22, n.1, p.203-213, 2001.

FNP CONSUlTORIA \& COMÉRCIO. AGRIANUAL 2005: anuário estatístico da agricultura brasileira. São Paulo, 2005. p.315-325: Citros.

FORNAZIER, R.F. Efeito do cádmio em plântulas e calos de cana-deaçucar : respostas do sistema antioxidante. Piracicaba, 2000. 81p. Dissertação (Mestrado) - Escola Superior de Agricultura 'Luiz de Queiroz', Universidade de São Paulo.

FOYER, C.H.; LELANDAIS, M.; KUNERT, K.J. Photoxidative stress in plants. Physiologia Plantarum, v.92, n.4, p.696-717, 1994.

GALSTON, A.W.; KAUR-SAWHNEY, R. Polyamines as endogenous growth regulators. In: DAVIES, P.J. (Ed.). Plant hormones and their role in plant growth and development. Dordrecht: Kluwer Academic, 1987. p.280-295.

GALSTON, A.W.; KAUR-SAWHNEY, R. Polyamines and senescence in plants. In: THOMPSON, W.; NOTHANGEL, E.; HUFFAKER, R. (Ed.). Plant senescence: its biochemistry and physiology. Rockville: Amer. Soc. Plant Physiol. 1988. p.176-181. 
GARDNER, P.T.; WHITE, T.A.C.; McPHAIL, D.B. et al. The relative contribuitions of vitamin $\mathrm{C}$, carotenoids and phenolic to the antioxidants potencial of fruit juices. Food chemistry, v.68, p.471474, 2000.

GONZALES-AGUILAR, G.A.; ZACARIAS, L.; LAFUENTE, M.T. Ripening affects high-temperature-induced polyamines and their changes during cold storage of hybrid Fortune mandarins. Journal of Agriculture and Food Chemistry, v.46, p.3503-3508, 1998.

GONZALES-AGUILAR, G.A.; ZACARIAS, L.; MULAS, M. et al. Temperature and duration of water dips influence chilling injury, decay and polyamine content in 'Fortune' mandarins. Portharvest Biology and Technology, v.12, p.61-69, 1997.

GRIERSON, D. Senescence in fruits. Hortscience, v.22, n.5, p.859-862, 1987.

GUYE, M.G.; VIGH, L.; WILSON, J.M. Polyamine titre in relation to chillsensitivity in Phaseolus sp. Journal of Experimental Botany, v.37, p.1036-1043, 1986.

HARDENBURG, R.E.; WATADA, A.E.; WANG, C.Y. Commercial storage of fruits, vegetables, and florist, and nursery stocks. Washington: USDA, 1986. 130p. (Agriculture Handbook, 66). 
HEWETT, E.W. Postharvest heat treatments: effects on commodity, pathogens and insect pests. Chronica Horticulturae, v.40, n.2, p.910, 2000.

HODGES, D.M.; FORNEY, C.F. The effect of ethylene depressed oxygen and elevated carbon dioxide on antioxidant profiles senescing spinach leaves. Journal of Experimental Botany, v.51, p.645-655, 2000.

HOLLAND, N.; MENEZES, H.C.; LAFUENTE, M.T. Carbohydrates as related to the heat-induced chilling tolerance and respiratory rate of 'Fortune' mandarin fruit harvested at different maturity stages. Postharvest Biology and Technology, v.25, n.2, p.181-191, 2002.

INZÉ, D.; PARKIN, K.L. Oxidative stress in plants. Current Opinion in Biotechnology, v. 6, n.2, p.153-158, 1995.

ITURBE-ORMAETXE, T.; ESCUREDO, P.R.; ARRESE-IGOR, C. et al. Oxidative damage in peã plants exposed to water déficit or paraquat. Plant Physiology, v. 116, p.173-181, 1998.

JACOB, S.T.; STETLER, D.A. Polyamines and RNA synthesis. In: BACHRACH, U.; HEIMER, Q.M. (Ed.). The physiology of polyamines. Boca Raton: CRC Press, 1991. v.1, p.133-140.

JIANG, Y.; JOYCE, D.C.; MACNISH, A.J. Extension of the shelf life of banana fruit by 1-methylcyclopropene in combination with polyethylene bags. Postharvest Biology and Technology, v.16, p.187-193. 1999a. 
JIANG, Y.; JOYCE, D.C.; MACNISH, A.J. Responses of banana fruit to treatment with 1-methylcyclopropene. Plant Growth Regulation, v.28, p.77-82, 1999b.

JOBLING, J.; McGLASSON, W.B.; DILLEY, D.R. Induction of ethylene synthesizing competency in Granny Smith apples by exposure to low temperature in air. Postharvest Biology and Technology, v.1, p.111-118, 1991.

JOMORI, M.L.L.; KLUGE, R.A,; JACOMINO, A.P. et al. Conservação refrigerada de lima ácida 'Tahiti': uso de 1-metilciclopropeno, ácido giberélico e cera. Revista Brasileira Fruticultura, v.25, n.3, p.406409, 2003.

JU, Z.; YUAN, Y.; LIOU, C.; et al. Effects of low temperature on $\mathrm{H}_{2} \mathrm{O}_{2}$ and heart browning of Chili and Yali pear (Pyrus bretscheideri, R.) Science Agricola Sinica, v.27, p.77-81, 1994.

JUN, P.G.; NISHIMURA, N.; KUBO, Y. et al. Biosynthesis of traceethylene in some fruits. Journal of the Japanese Society for Horticultural Science, v.61, n.1, p.199-204, 1999.

KADER, A.A.; ARPAIA, M. L.Posthaverst handling syatem: subtropical fruits. In: KADER, A.A. (Ed.). Posthaverst technology of horticultural crops. Oakland: University of California, 1992. p.233240.

KADER, A.A.; MORRIS, L.L. Ameliation of chilling injury symptoms on tomato fruits. HortScience, v. 10, p.324-325, 1975. 
KLUGE, R.A.; JOMORI, M.L.L.; JACOMINO, A.P. et al. Intermittent warming in 'Tahiti' lime treated with an ethylene inhibitor. Postharvest Biology and Technology, v.29, p.195-203, 2003.

KLUGE, R.A.; NACHTIGAL, J.C.; FACHINELLO, J.C. et al. Fisiologia e manejo pós-colheita de frutas de clima temperado. 2.ed. Piracicaba: Livraria e Editora Rural, 2002. 214p.

KLUGE, R.A.; SCARPARE FILHO, J.A.; JACOMINO, A.P. et al. Distúrbios fisiológicos em frutos. Piracicaba, FEALQ, 2001. 58p.

KRAMER, G.F.; WANG, Y. Correlation of reduced chilling injury with increased spermine and spermidine levels in zuccnini squash. Journal of Plant Physiology, v.76, p.479-484, 1989.

KRAUS, T.E.; EVANS, R.C.; FLETCHER, R.A. et al. Paclobutrazol enhances tolerances to increased levels of UV-B radiation in soybean (Glycine max) seedlings. Canadian Journal of Botany, v.73, n.6, p.797-806, 1995.

KURATA, H.; ITO, T.; ADACHI, M. et al. Ethylene - enhance chlorophyll catabolism in Citrus unshiu fruit: effects of inhibitors on the activity of enzymes involved in type I reactions. Journal of the Japanese Society for Horticultural Science, v.68, n.4, p.825-829, 1999.

LARRIGAUDIERE, C.; VENDRELL, M. Short-term activation of the conversion of 1-amino-cyclopropane-1-carboxylic acid to ethylene in rewarmed Granny Smith apples. Plant Physiology, v.31, p.585-592, 1993. 
LARSON, R.A. The antioxidants of higher plants. Phytochemistry, v.27, p.696-678, 1988.

LEDERMAN, I.E.; ZAUBERMAN, G.; WEKSLER, A. et al. Ethyleneforming capacity during cold storage and chilling injury development in 'Keitt' mango fruit. Postharvest Biology and Technology, v.10, n.1, p.107-112, 1997.

LEE, S.K.; YOUNG, R.E. Temperature sensitivity of avocado fruit in relation to $\mathrm{C}_{2} \mathrm{H}_{4}$ treatment. Journal of the American Society for Horticultural Science, v. 109, p.689-692, 1984.

LELIÈVRE, J.M.; LATCHÉ, A.; JONES, B. et al. Ethylene and fruit ripening. Physiologia Plantarum, v.101, p.727-739, 1997.

LEVINE, R.L.; MOSONI, B.S.; BERLETT, B.S. et al. Methionine residues as endogenous antioxidants in proteins. Proceedings of the National Academy of Sciences of the USA, v.93, p.15036-15040, 1996.

LIMA, G.P.P. Marcadores bioquímicos de injúrias pelo frio e de maturação em bananas (Musa acuminata AAA Simm. \& Shep. cv nanica). Botucatu, 2000. 118p. Tese (Livre-docência) - Faculdade de Ciências Agronômicas, Universidade Estadual Paulista.

LIMA, G.P.P.; BRASIL, O.G.; OLIVEIRA, A.M. Poliaminas e atividade de peroxidase em feijão (Phaseolus vulgaris L.) cultivado sob estresse salino. Scientia Agricola, v.56, n.1, 1999. 
LIPTON, W.J.; AHARONI, Y. Chilling injury and ripening of 'Honeydew' muskmelon stored at 2.5 or $5^{\circ} \mathrm{C}$ after ethylene treatment a $20^{\circ} \mathrm{C}$. Journal of the American Society for Horticultural Science, v.104, p.327-330, 1979.

LIU, F.W. Modification of apple quality by high-temperature. Journal of the American Society for Horticultural Science, v.103, n.3, p.730$732,1978$.

LURIE, S. Postharvest heat treatments. Postharvest Biology and Technology, v.14, p.257-269, 1998.

LURIE, S.; KLEIN, J.D. Heat treatment of ripening apples: differential effects on physiology and biochemistry. Physiologia Plantarum, v. 78, n.2, p.181-186, 1990.

LURIE, S.; KLEIN, J.D. Acquisition of low-temperature tolerance in tomatoes by exposure to high-temperature stress. Journal of the American Society for Horticultural Science, v.116, n.6, p. 1007$1012,1991$.

McCOLLUM, T.G.; McDONALD, R.E. Electrolyte leakage, respiration and ethylene production as indices of chilling injury in grapefruit. Hortscience, v.26, p.1191-1192, 1991.

McDONALD, R.E.; KUSHAD, M.M. Accumulation of putrescine during chilling injury of fruits. Plant Physiology, v. 82, p. 324-326, 1986. 
MANFROI, V.; LUCCHESE, O.A.; CARVALHO, R.I.N. et al. Efeito do 2,4D na frigoconservação de limão Tahiti (Citrus latifólia Tanaka). Boletim CEPPA, v. 14, n. 1, p. 77-88, 1996.

MARTÍNEZ-TELLÉZ, M.A.; LAFUENTE, M.T. Effect of high temperature conditioning on ethylene, phenylalanine ammonia-lyase, peroxidase and polyphenol oxidase activities in flavedo of chilled 'Fortune' mandarin fruit. Journal of Plant Physiology, v.150, p.674-678, 1997.

MASIA, A. Superoxide dismutase and catalase activities in apple fruit during ripening and post-harvest and with special reference to ethylene. Physiologia Plantarum, v.104, n.4, p.668-672, 1998.

MIZOBUTSI, G.P.; BORGES, C.A.M.; SIQUEIRA, D.L. Conservação póscolheita da lima ácida 'Tahiti' (Citrus latifolia Tanaka), tratada com ácido giberélico e armazenada em três temperaturas. Revista Brasileira de Fruticultura, v.22, p.42-47, 2000.

MONK, L.S.; FAGERSTEDT, K.V.; CRAWFORD, R.M.M. Oxygen toxicity and superoxide dismutase as an antioxidant in physiological stress. Physiologia Plantarum, v.76, p.456-459, 1989.

MORÃO, F.A.A. Limão tahiti é na verdade uma lima ácida. Agropecuariahoje, v. 3, n. 12, p. 10, mar./abr. 1997. 
NOCTOR, G.; FOYER, C.H. Ascorbate and glutathione: keeping active oxygen under control. Annul Review of Plant Physiology and Molecular Biology, v.49, p.249-279, 1998.

NOCTOR, G.; GOMEZ, L.; VANACKER, H. et al. Interactions between biosynthesis, comportmentation and transport in the control of glutathione homeostasis and signaling. Journal of Experimental Botany, v.53, n. 372, p. 1283-1304, 2002.

PAULL, R.E.; JUNG CHEN, N. Heat treatment and fruit ripening. Postharvest Biology and Technology, v.21, n.1, p.21-37, 2000.

PESIS, E.; ACKERMAN, M.; BEN-AIRE, R. et al. Ethylene involvement in chilling injury symptoms of avocado during cold storage. Postharvest Biology and Technology, v.24, p.171-181, 2002.

PLAZA, P.; SANBRUNO, A.; USALL, J. et al. Integration of curing treatments with degreening to control the main postharvest diseases of clementine mandarins. Postharvest Biology and Technology, v.34, p.29-37, 2004.

PORAT, R.; WEISS, B.; COHEN, L. et al. Effects of ethylene and 1methylcyclopropene on the postharvest qualities of 'Shamouti' oranges. Postharvest Biology and Technology, v.15, n.2, p.155$163,1999$. 
PRASAD, T.K.; ANDERSON, M.D.; STEWART, C.R. Acclimation, hydrogen peroxide, and abscisic acid protect mitochondria against irreversible chilling injury in mayze seedlings. Plant Physiology, v.105, p.619-627, 1994.

PURVIS, A.C.; SHEWFELT, R.L. Does the alternative pathway ameliorate chilling injury in sensitive plant tissues? Plysiology Plantarum, v.88, p.712-718, 1993

RAO, M.V.; PALIYATH, G.; ORMROD, D.P. Ultraviolet-B- and ozoneinduced biochemical changes in antioxidant enzymes of Arabidopsis thaliana. Plant Phisiology, v.110, p.125-136, 1996.

ROBARDS, K.; PRENZLER, G.; TUCKER, G. et al. Phenolic compounds and their role in oxidative processes in fruits. Food Chemistry, v.66, p.401-436, 1999.

RODOV, V.; AGAR, T.; PERETZ, J. et al. Effect of combined application of heat treatments and plastic packaging on keeping quality of 'Oroblanco' fruit (Citrus grandis L. x C. paradisi Macf.). Postharvest Biology and Technology, v.20, p.287-294, 2000.

RODOV, V.; BEN-YEHOSHUA, S.; ALBAGLI, R. et al. Reducing chilling injury and decay of stored citrus by hot water dips. Postharvest Biology and Technology, v.5, p.119-127, 1995. 
SALA, J.M. Involvement of oxidative stress in chilling injury in coldstored mandarin fruits. Postharvest Biology and Technology, v.13, p.255-161, 1998.

SALA, J.M.; LAFUENTE, M.T. Catalase in the heat-induced chilling tolerance of cold-stored hybrid Fortune mandarin fruits. Journal of Agriculture and Food Chemistry, v.47, p.2410-2414, 1999.

SALA, J.M.; LAFUENTE, M.T. Catalase enzyme activity is related to tolerance of mandarin fruits to chilling. Postharvest Biology and Technology, v.20, p.81-89, 2000.

SALA, J.M.; LAFUENTE, M.T. Antioxidant enzymes activities and rindstaining in 'Navelina' oranges as affected by storage relative humidity and ethylene conditioning. Postharvest Biology and Technology, v.31, n.3, p.277-285, 2004.

SALVADOR, A.; CUQUERELLA, J.; MARTINEZ-JÁVEGA, J.M. 1-MCP treatment prolongs postharvest life of 'Santa Rosa' plums. Journal Food Science, v.68, p.1504-1510, 2003.

SALVADOR, A.; ARNAL, L.; MONTEVERDE, A. et al. Reduction of chilling injury symptoms in persimmon fruit cv. 'Rojo Brillante' by 1MCP. Postharvest Biology and Technology, v.33, n.3, p.285-291, 2004.

SCANDALIOS, J.G. Oxygen stress and superoxide dismutase. Plant Physiology, v.101, p.7-12, 1993. 
SCANDALIOS, J.G. Response of plant antioxidant defense genes to environmental stress. Advances in Genetics, v.28, p.1-41, 1990.

SCHIRRA, M.; COHEN, E. Long-term storage of 'Olinda' oranges under chilling and intermittent warming temperatures. Postharvest Biology and Technology, v.16, p.63-69, 1999.

SCHIRRA, M.; MULAS, M. Keeping quality of 'Oroblanco' grapefruit-type as affected by hot dip treatments. Advances in Horticultural Science, v.7, p.73-76, 1993.

SCHIRRA, M.; MULAS, M. 'Fortune' mandarin quality following prestorage water dips and intermittent warming during cold storage. Hortiscience, v.30, n,3, p.551-560, 1995.

SCHIRRA, M.; AGABBIO, M.; D'HALLEWIN, G. et al. Responses of Tarocco oranges to picking date, postharvest hot water dip, and chilling storage temperature. Journal of Agriculture and Food Chemistry, v.45, p.3216+3220, 1997.

SCHIRRA, M.; MULAS, M.; FADDA, A. et al. Cold quarantine responses of blood oranges to postharvest hot water and hot air treatments. Postharvest Biology and Technology, v.31, n.2, p.191$200,2004$. 
SCHIRRA, M.; MULAS, M.; FADDA, A. et al. Chemical and quality traits of 'Olinda' and 'Campbell' oranges after heat treatment at 44 or $46{ }^{\circ} \mathrm{C}$ for fruit fly disinfestations. LWT - Food Science and Technology, v.38, n.5, p.519-527, 2005.

SCHUTZENDUBEL, A.; SCHWANZ, P.; TEICHMANN, T. et al. Cadmiuminduced changes in antioxidative systems, hydrogen peroxide content and differentiation in Scots pine roots. Plant Phisiology, v.127, p.887-898, 2001.

SELVARAJAH, S.; BAUCHOT, A.D.; JOHN, P. Internal browning in coldstored pineapples is suppressed by a postharvest application of 1methylcyclopropene. Postharvest Biology and Technology, v.23, p.167-170, 2001.

SEREK, M.; SISLER, E.C.; REID, M.S. 1-methylcyclopropene, a novel gaseous inhibitor of ethylene action, improves the life of fruit, cut flowers and potted plants. Acta Horticulturae, n.394, p.337-345, 1995.

SERRANO, M.; MARTINEZ-MADRID, M.C.; MARTINEZ, G. et al. Review: Role of polyamines in chilling injury of fruit and vegetables. Food Science and Technology International, v.2, n.4, p.195-199, 1996. 
SHAMAILA, M.; PWRIE, W.D.; SKURA, B.J. Sensory evaluation of strawberry fruit stored under modified atmosphere packaging (MAP) by quantative descriptive analysis. Journal of Food Science, v.57, p. 1168-1172, 1992.

SINCLAIR, W.B. The biochemistry and physiology of the lemon and other citrus fruits. Oakland: University of California, 1984. 946p.

SISLER, E.C.; SEREK, M. Inhibitors of ethylene responses en plants at the receptors level: recent developments. Physiologia Plantarum, v. 100, p.577-582, 1997.

SISLER, E.C.; SEREK, M.; DUPILLE, E. Comparison of cyclopropene, 1methycyclopropene, and 3,3-dimethylcyclopropene as ethylene antagonists in plants. Plant Growth Regulation, v.18, p.169-174, 1996.

SMIRNOFF, N. The role of Active oxygen in the response of plants to water deficit and desiccation. New Phytologist, v. 125, p.27-28, 1993.

SMIITH, M.A. Chromatographic methods for the identification and quantification of polyamines. In: SCOLUM, R.D.; FLORES, H.E. (Ed.). Biochemistry and physiology of polyamines in plants. Boca Raton: CRC Press, 1991. cap.16, p.229-242.

SRIVASTAVA, M.K.; DWIVEDI, U.N. Delayed ripening of banana fruit by salicylic acid. Plant Science, v.158, p.87-96, 2000. 
TATSUMI, Y.; KIMURA, I.; SUMATA, K. Relation betweem chilling sensitivity and polyamine content in several maturity stages of zucchini squash. Acta Horticulturae, n.398, p.215-221, 1995.

VALERO, D.; MARTÍNEZ-ROMERO, D.; SERRANO, M. The role of polyamines in the improvement of the shelf life of fruit. Trends in Food Science \& Technology, v.13, n.6-7, p.228-234, 2002.

VALERO, D.; MARINEZ-ROMERO, D.; SERRANO, M. et al. Polyamines roles on the postharvest of fruits: a review. In: PANDALAI, S.G. (Ed.). Recent research development in agricultural and food chemistry. Trivandrum: . Research Signpost. 1999. p. 39-55.

WANG, C.Y. Approaches to reduce chilling injury of fruits and vegetables. Horticultural Reviews, v. 15, p.63-95, 1993.

WANG, C.Y. Chilling injury of tropical horticultural commodities. Hortscience, v.29, n.9, p.986-988, 1994.

WANG, C.Y. Effect of temperature preconditioning on catalase, peroxidase, and superoxide dismutase in chilled zucchini squash. Postharvest Biology and Technology, v.5, p.67-76, 1995.

WANG, C.Y.; JI, Z.L. Effect of low-oxigen storage on chilling injury and polyamines in zucchini squash. Scientia Horticulturae, v.39, p. 17, 1989. 
WILlEKENS, H.; CHAMNONGPOL, S.; DAVEY, M. et al. Catalase is a sink for $\mathrm{H}_{2} \mathrm{O}_{2}$ and is indispensable for stress defense in C3 plants. EMBO Journal, v.16, n.16, p.4806-4816, 1997.

WILLEKENS, H.; INZÉ, D.; VAN MONTAGU, M. et al. Catalases in plants. Molecular Breeding, v. 1, p.207-228, 1995.

WISE, R.R.; NAYLOR, A.W. Chilling-enhanced photooxidation. The peroxidative destruction of lipids during chilling injury to photosynthesis and ultrastructure. Plant Physiology, v.83, p.272277, 1987.

YANG, S.F.; HOFFMANN, N.E. Ethylene biosynthesis and its regulation in higher plants. Annual Review of Plant Physiology, v.35, p.155189, 1984.

YU, Y-B.; ADAMS, D.O.; YANG, S.F. Inhibition of ethylene production by 2,4-dinitrophenol and high temperature. Plant Physiology, v.66, p.286-290, 1980.

YUEN, C.M.C.; TRIDJAJA, N.N.; WILLS, R.B.H. et al. Chilling injury development of 'Tahitian' lime, 'Emperor' mandarin, 'Marsh' grapefruit and 'Valência' orange. Journal of Science of Food and Agriculture, v.67, p.335-339, 1995.

ZHENG, R.; YANG, Z. Lipid peroxidation and antioxidative defense systems in early leaf growth. Journal of Plant Growth Regulation, v.10, p.187-199, 1991. 